\title{
29. CHERT PETROLOGY AND GEOCHEMISTRY, MID-PACIFIC MOUNTAINS AND HESS RISE, DEEP SEA DRILLING PROJECT LEG 62 ${ }^{1}$
}

\author{
James R. Hein, Tracy L. Vallier, and Mary Ann Allan \\ U.S. Geological Survey, 345 Middlefield Road, Menlo Park, California
}

\begin{abstract}
Sixty-five chert, porcellanite, and siliceous-chalk samples from Deep Sea Drilling Project Leg 62 were analyzed by petrography, scanning electron microscopy, analysis by energy-dispersive X-rays, X-ray diffraction, X-ray spectroscopy, and semiquantitative emission spectroscopy. Siliceous rocks occur mainly in chalks, but also in pelagic clay and marlstone at Site 464 . Overall, chert probably constitutes less than $5 \%$ of the sections and occurs in deposits of Eocene to Barremian ages at sub-bottom depths of 10 to 820 meters. Chert nodules and beds are commonly rimmed by quartz porcellanite; opal-CT-rich rocks are minor in Leg 62 sediments 65 to $108 \mathrm{~m} . y$. old and at sub-bottom depths of 65 to 520 meters. Chert ranges from white to black, shades of gray and brown being most common; yellow-brown and red-brown jaspers occur at Site 464.

Seventy-eight percent of the studied cherts contain easily recognizable burrow structures. The youngest chert at Site 463 is a quartz cast of a burrow. Burrow silica maturation is always one step ahead of host-rock silicification. Burrows are commonly loci for initial silicification of the host carbonate. Silicification takes place by volume-for-volume replacement of carbonate sediment, and more-clay-rich sediment at Site 464. Nannofossils are commonly pseudomorphically replaced by quartz near the edges of chert beds and nodules. Other microfossils, mostly radiolarians and foraminifers, whether in chalk or chert, can be either filled with or replaced by calcite, opal-CT, and (or) quartz.

Chemical micro-environments ultimately control the removal, transport, and precipitation of calcite and silica. Two cherts from Site 465 contain sulfate minerals replaced by quartz. Site 465 was never subaerially exposed after sedimentation began, and the formation of the sulfate minerals and their subsequent replacement probably occurred in the marine environment. Several other cherts with odd textures are described in this paper, including (1) a chert breccia cemented by colloform opal-CT and chalcedony, (2) a transition zone between white porcellanite containing opal-CT and quartz and a burrowed brown chert, consisting of radial aggregates of opal-CT with hollow centers, and (3) a chert that consists of silica-replaced calcite pseudospherules interspersed with streaks and circular masses of dense quartz.

$\mathrm{X}$-ray-diffraction analyses show that when data from all sites are considered there are poorly defined trends indicating that older cherts have better quartz crystallinity than younger ones, and that opal-CT crystallite size increases and opal-CT $d$-spacings decrease with depth of occurrence in the sections. In a general way, depth of burial and the presence of calcite promote the ordering in the opal-CT crystal structure which allows its eventual conversion to quartz. Opal-CT in porcellanites converts to quartz after reaching a minimum $d$-spacing of $4.07 \AA$. Quartz/opal-CT ratios and quartz crystallinity vary randomly on a fine scale across four chert beds, but quartz crystallinity increases from the edge to the center of a fifth chert bed; this may indicate maturation of the silica.

Twenty-four rocks were analyzed for their major- and minor-element compositions. Many elements in cherts are closely related to major mineral components. The carbonate component is distinguished by high values of $\mathrm{CaO}, \mathrm{MgO}$, $\mathrm{Mn}, \mathrm{Ba}, \mathrm{Sr}$, and (for unknown reasons) $\mathrm{Zr}$. Tuffaceous cherts have high values of $\mathrm{K}$ and $\mathrm{Al}$, and commonly $\mathrm{Zn}, \mathrm{Mo}$, and $\mathrm{Cr}$. Pure cherts are characterized by high $\mathrm{SiO}_{2}$ and $\mathrm{B}$. High $\mathrm{B}$ may be a good indicator of formation of chert in an open marine environment, isolated from volcanic and terrigenous materials.
\end{abstract}

\section{INTRODUCTION}

Chert and other siliceous sediments recovered by the Deep Sea Drilling Project have received considerable attention. Many reports focus on details of petrography and mineralogy based on thin-section, SEM, and X-raydiffraction studies (Calvert, 1971; Heath and Moberly, 1971; Greenwood, 1973; Lancelot, 1973; Wise and Weaver, 1974; Garrison et al., 1975; Hein et al., 1978; von Rad et al., 1979; among others). Particularly important to our understanding of the nature of deep sea siliceous sediments and their time and space relationships are the compilations and syntheses by Keene (1976) of Pacific data through DSDP Leg 32, and by Riech and von Rad (1979) of Atlantic data through DSDP Leg 50.

\footnotetext{
1 Initial Reports of the Deep Sea Drilling Project, Volume 62.
}

Chert, commonly with rims of porcellanite, occurs as nodules and beds in carbonate sediments drilled during Leg 62. In this report, most aspects of petrography and mineralogy will be discussed only briefly, because many of the petrographic characteristics of Leg 62 cherts are the same as those described in earlier studies. We will present special aspects of the mineralogy, such as quartz crystallinity, opal-CT $d$-spacings, and opal-CT crystallite sizes. The chemistry of chert, notably neglected in earlier studies, will also be emphasized. Other topics not stressed in earlier works that are discussed in this report include the widespread nondestructive replacement of calcareous nannofossils by silica and the impact of faunal burrowing on the process of silicification and on the formation of chert.

\section{GEOLOGIC SETTING}

During Leg 62, chert and porcellanite were recovered at Site 463, on the Mid-Pacific Mountains, and at Sites 
464, 465, and 466, on Hess Rise (Figs. 1 and 2). At all sites, chert probably constitutes less than $5 \%$ of the sections, as determined from drilling logs and recovery percentages. Details of the stratigraphy can be learned from Figure 2 and the site report chapters of this volume. In general, sediment at Site 463 is 822.5 meters of Quaternary through upper Barremian nannofossil ooze, chalk, and limestone, with minor amounts of chert and volcanic ash. Site 464 is underlain by 310 meters of Quaternary to upper Miocene clayey radiolarian ooze and siliceous clay, lower Miocene to upper Cretaceous(?) brown clay, and Cenomanian to lower Albian chert and nannofossil limestone, which overlies highly altered tholeiitic basalt. At Site 465 (Holes 465 and $465 \mathrm{~A}$ ) on southern Hess Rise, cores representing about 420 meters of Quaternary to upper Albian calcareous ooze, limestone, and minor chert were recovered; underlying the limestone is highly altered trachyte, of which 64 meters were cored. At Site 466, also on southern Hess Rise, 312 meters of Quaternary to upper Albian calcareous sediments with minor chert and pyritic clay were cored.

\section{TERMINOLOGY}

In this paper, chert is used as a compositional and textural term to define a silica-rich, hard, dense, and vitreous sedimentary rock; porcellanite, is a less-dense and hard, more-porous, siliceous sedimentary rock, commonly with impurities such as clays and carbonates, with the appearance of unglazed porcelain. In the deep sea and in orogenic belts, silica in most cherts is quartz and chalcedony, whereas silica in most porcellanites is opal-CT. These silica phases can be assumed for the samples studied here unless the terms chert and porcellanite are modified by a mineral name, for example opal-CT chert or quartz porcellanite. Leg 62 por-

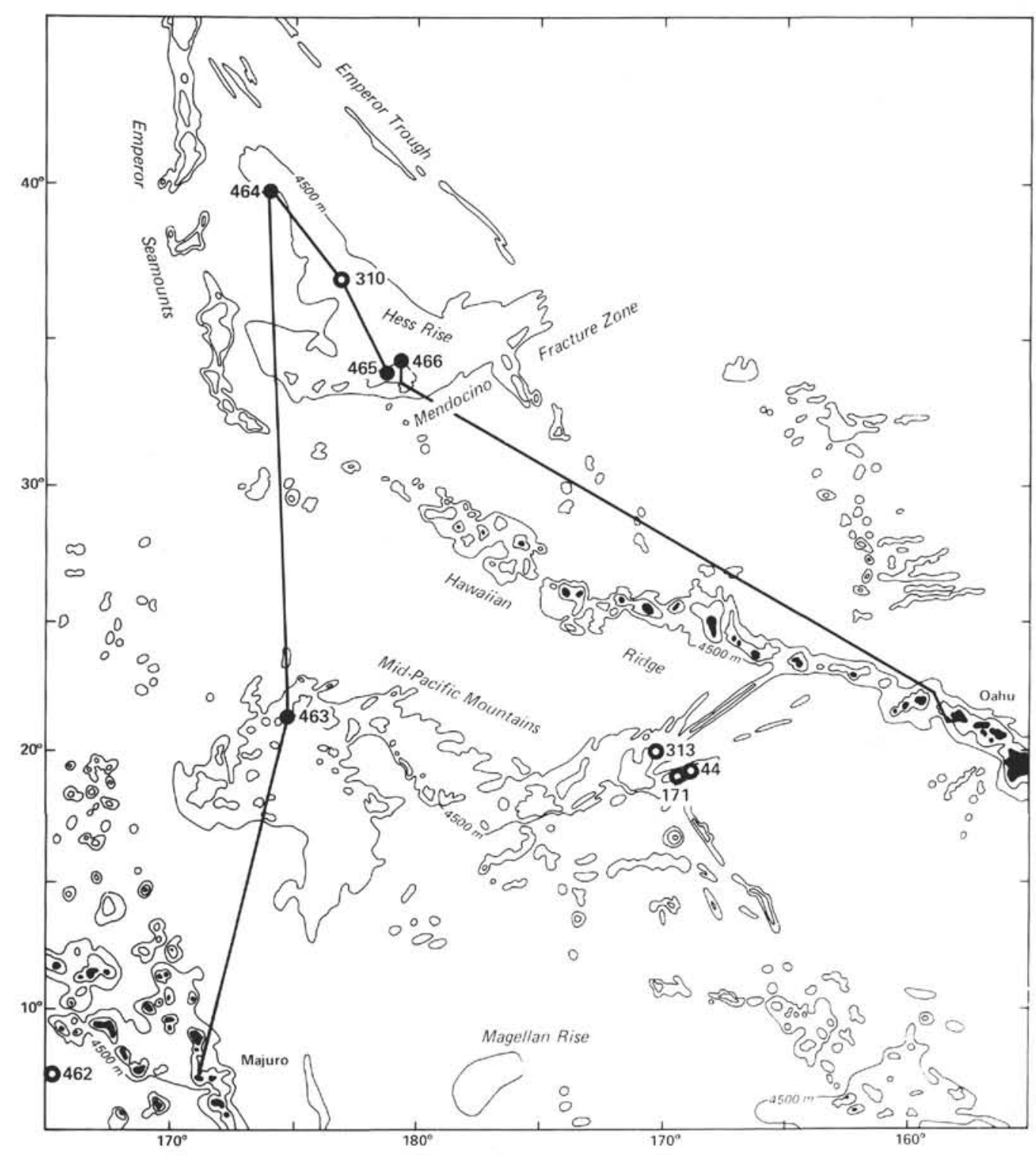

Figure 1. Location of DSDP Leg 62 Sites 463, 464, 465, and 466. 
cellanites are atypical in that most of them are quartz porcellanites. We use the terminology for silica minerals of Jones and Segnit (1971): opal-A is hydrated silica amorphous to X-rays and is the main constituent of biogenic silica, such as tests and frustules of radiolarians, diatoms, and silicoflagellates, and sponge spicules; opal-CT is interlayered $\alpha$-cristobalite and $\alpha$-tridymite (Flörke, 1955), although Oehler (1973) and Wilson et al. (1974) suggested that opal-CT may be solely tridymite. In general, biogenic opal-A transforms into opal-CT, which in turn transforms into quartz during diagenesis (Murata and Larson, 1975; Hein et al., 1978; Kastner et al., 1977). Typically, but not invariably, the mineralogical transformations are accompanied by textural tranformations (Ernst and Calvert, 1969): siliceous ooze $\rightarrow$ porcellanite $\rightarrow$ chert.

\section{METHODS}

Sixty-five chert, porcellanite, and siliceous-chalk samples were analyzed by petrography, scanning electron microscopy (SEM), analysis by energy-dispersive X-rays (EDAX), X-ray diffraction (XRD), $\mathrm{X}$-ray spectroscopy (XRF), and semiquantitative emission spectroscopy (ES).

A Cambridge 180 stereoscan SEM-EDAX system was used for gold-palladium-coated samples. HF-etched and untreated fracture surfaces of each sample were compared. Etched surfaces showed much better textural and mineralogical relations that did untreated ones.

Bulk rock and mineral separates were analyzed by XRD, using a Norelco diffractometer equipped with a curved-crystal carbon monochrometer and theta-compensating slit. Techniques of XRD for silica phases are described in detail by Hein et al. (1978). Opal-CT $d$-spacings were determined after the technique of Murata and Larson (1975), as described by Hein et al. (1978); techniques of quartzcrystallinity measurement are after Murata and Norman (1976); and opal-CT crystallite sizes were measured perpendicular to $d$ (101), using the Scherrer equation (Klug and Alexander, 1954). Quartz/opal-CT ratios were calculated by comparing the combined $4.10 \AA$ cristobalite and $4.24 \AA$ tridymite peak heights to the $3.34 \AA$ quartz peak height. Fourteen percent of the quartz $3.34 \AA$ peak height is subtracted from the tridymite peak height, because of overlap of the $4.246 \AA$ quartz and $4.25 \AA$ tridymite spacings. The $86 / 14$ ratio for the primary and secondary quartz peaks was determined from pure quartz cherts from Leg 62. This technique for determining quartz/opal-CT ratios underestimates the amount of opal-CT, because these two minerals do not have a $1: 1$ correlation coefficient; the quartz/opal-CT correlation coefficient depends on the crystallinity of each mineral and probably falls between 1:6 and 1:9 (Cook et al, 1975; Pisciotto, 1978). Thus the values of quartz/opal-CT listed in Table 1 may be too large by a factor of between 6 and 9 .

Percentages of major oxides and Mn were determined by X-ray spectroscopy, and minor elements by six-step semiquantitative emission spectroscopy. Both procedures were completed at the U.S. Geological Survey analytical laboratories. Total volatiles were determined by loss on fusion at $1050^{\circ} \mathrm{C}$.

\section{STRATIGRAPHY AND LITHOLOGY}

At Site 463, chert beds and nodules occur in carbonate sediments of the Eocene through the upper Barremian, at sub-bottom depths of 46 to 822.5 meters (Fig. 2; Appendix). Chert is most common in upper Aptian and Albian deposits. At Site 464, chert is abundant in Cenomanian through lower Albian sediments, at subbottom depths of 50 to 308 meters. Chert occurs in brown clays in Late Cretaceous(?) deposits and is interbedded with chalks and marlstones in older deposits, although very little of the softer carbonate interbeds was recovered. At Site 465, chert occurs in upper Paleocene through upper Albian carbonate deposits, at subbottom depths of 10 to 412 meters. The youngest chert, at 10 meters is just below a 50-m.y. hiatus. Chert is apparently most abundant in upper Albian and lowerMaastrictian sediments. At Site 466, chert occurs in deposits of the upper Eocene through the upper Albian, at sub-bottom depths of 65 to 312 meters. Coniacian to lower Turonian cherts are apparently most abundant.

Chert ranges from nearly transparent to black, shades of brown and gray being most common (Table 1 ); a single sample can be two or more colors. Redbrown and yellow-brown jasper occurs at Site 464, and rarely at Site 466 . Beds and nodules are mostly less than 4-cm thick, but thickness is often difficult to determine, because drilling extensively fragments the rocks. A thin layer of porcellanite or quartz porcellanite clings to the upper and lower surfaces of most chert fragments. (At Sites $463,464,465$, and $466,75 \%, 47 \%, 67 \%$, and $70 \%$ respectively of the cherts have porcellanite rims; $8 \%$, $47 \%, 33 \%$, and $20 \%$ respectively of cherts occur without rims, and $17 \%, 6 \%, 0 \%$, and $10 \%$ are porcellanite, calcareous porcellanites, or siliceous chalks without associated cherts. Overall, $66 \%$ of cherts have porcellanite rims, $14 \%$ do not have rims, and $10 \%$ of siliceous rocks do not include cherts.)

In some porcellanites, and rarely in cherts, varying amounts of admixed carbonate occur (Table 1). In general, cherts at Site 464 are in more-clay-rich deposits-such as pelagic clays and marlstones-compared to cherts in the carbonate-ooze sections at the other three sites.

In hand specimen, cherts are vitreous and have a conchoidal fracture, whereas porcellanites are commonly indistinguishable from chalk, and grade (over millimeters) imperceptibly into chalk. Some chert specimens are finely laminated and others are color-banded, but most are massive and extensively burrowed. Burrows are evident as quartz replacements in chalk and porcellanite, as structures composed of quartz porcellanite in chert, as differences in color (commonly lighter) within chert, and rarely as pyrite replacements (Plate 1; volume frontispiece). Burrows are tentatively placed in three categories: Chondrites, Zoophycos, and Cylindrichnus or Planolites (Table 2, back pocket, this volume). Burrow structures are commonly well preserved, even in dense, pure quartz chert, to the extent that the curved disk structures in Zoophycos are easily recognizable.

On the average, $78 \%$ of studied chert specimens contain easily recognizable burrow structures; specifically $81,73,77$, and $80 \%$ of the sampled cherts from Sites $463,464,465$, and 466 respectively are burrowed. Even higher percentages of cherts may be burrowed, considering that some of the indistinct color mottling probably represents remnants of burrows. Details about the chert burrows will be presented in the section on petrography. Unfortunately, the distribution and types of burrows in the carbonate and clay sections were not noted during shipboard description of the cores, so burrows in chert and in the host carbonates cannot be compared. 
SITE 463

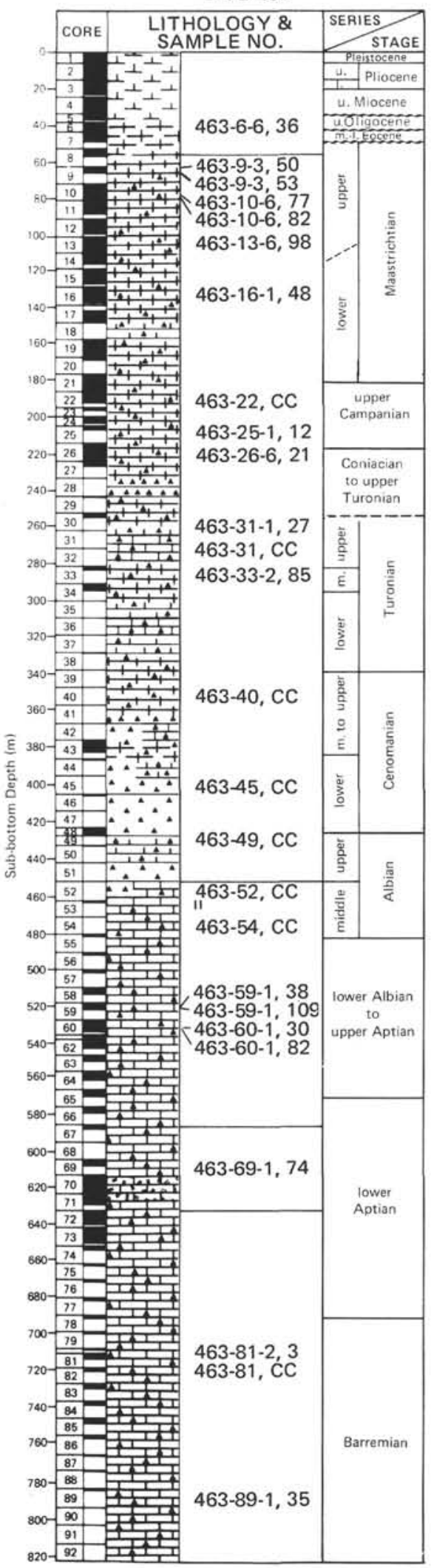

SITE 464

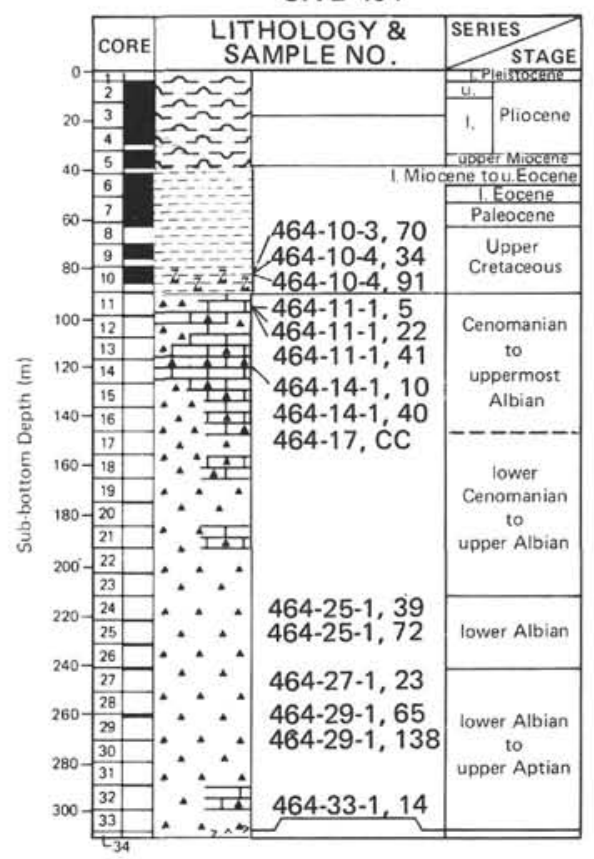

Figure 2. General lithologies, and ages of Leg 62 Sites, and stratigraphic locations of studied siliceous rocks. See Table 1 for description of each rock studied. Much of the chalk and marlstone interbedded with the chert, below the clay section at Site 464 , was not recovered during the coring operations. 


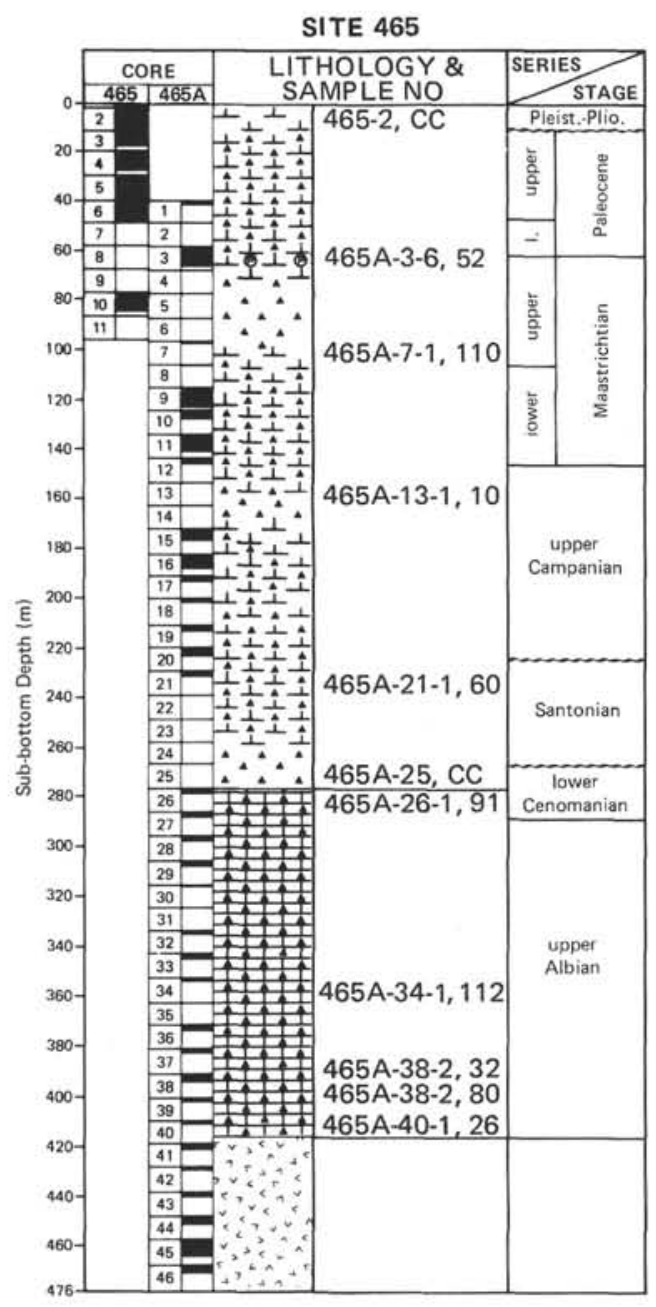

LEGEND

Calcareous ooze

Figure 2. (Continued).

\section{X-RAY MINERALOGY}

In samples from DSDP Leg 62, the silica phase in chert is always quartz or chalcedony, whereas porcellanite contains quartz and (or) opal-CT. Porcellanite also commonly contains moderate amounts of calcite (Table 1). A gradational sequence occurs from chalk

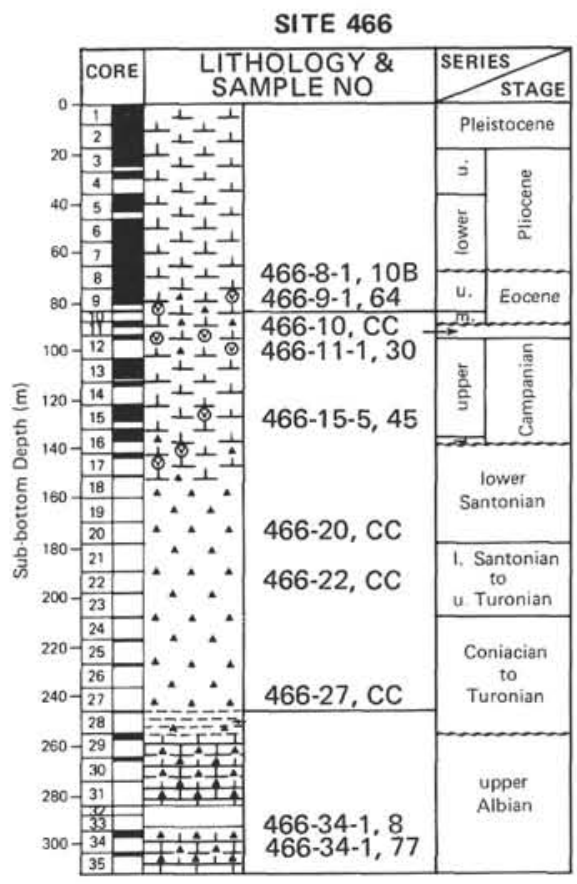

(calcite) to siliceous chalk (calcite + quartz or opal-CT) to calcareous porcellanite (quartz \pm opal-CT + calcite) to chert (quartz). Many chert and porcellanite samples contain a trace of smectite; some have trace amounts of barite, apatite, pyrite, and feldspar, and still others contain trace amounts of protodolomite, illite, clinoptilolite, goethite, pyroxene, rhodochrosite, and sulfates 
J. R. HEIN, T. L. VALLIER, M. A. ALLAN

Table 1. Characteristics of DSDP Leg 62 siliceous rocks.

\begin{tabular}{|c|c|c|c|c|c|c|c|c|c|c|c|c|}
\hline \multirow{3}{*}{$\begin{array}{r}\text { Sample } \\
464-11-1,5\end{array}$} & \multirow{3}{*}{$\begin{array}{l}\text { Age of Host } \\
\text { Sediment } \\
\text { Cenomanian }\end{array}$} & \multirow{3}{*}{$\begin{array}{c}\begin{array}{c}\text { Sub-bottom } \\
\text { Depth } \\
(\mathrm{m})\end{array} \\
89.1\end{array}$} & \multirow{3}{*}{$\begin{array}{l}\text { Lithology } \\
\text { Quartz-opal-CT porcellanite } \\
\text { breccia }\end{array}$} & \multirow{3}{*}{\begin{tabular}{l}
\multicolumn{1}{c}{$\begin{array}{c}\text { Thin-Section } \\
\text { Lithology }\end{array}$} \\
Colloform quartz-and \\
chalcedony-cemented breccia \\
with Fe-oxide-clay-rich \\
microquartz clasts
\end{tabular}} & \multicolumn{3}{|c|}{ General X-Ray Mineralogy } & \multirow{2}{*}{\multicolumn{2}{|c|}{$\begin{array}{l}\text { Quartz/ } \\
\text { Opal-CT }\end{array}$}} & \multirow{3}{*}{$\begin{array}{c}\text { Quartz } \\
\text { Crystallinity } \\
-\end{array}$} & \multirow{3}{*}{$\begin{array}{c}\begin{array}{c}\text { Opal-CT } \\
d \text {-Spacing } \\
(\text { A })\end{array} \\
4.095\end{array}$} & \multirow{3}{*}{$\begin{array}{c}\text { Opal-CT } \\
\text { Crystallite } \\
\text { Size }\end{array}$} \\
\hline & & & & & Major & Moderate & Trace & & & & & \\
\hline & & & & & $\begin{array}{l}\text { Opal-CT, } \\
\text { quartz }\end{array}$ & - & $\begin{array}{l}\text { Illite, } \\
\text { pyrite, } \\
\text { feldspar. } \\
\text { apatite? }\end{array}$ & (C) & 0.3 & & & \\
\hline $464-11-1,22$ & Cenomanian & 89.2 & $\begin{array}{l}\text { Laminated dark-brown chert } \\
\text { and light-brown quartz- } \\
\text { opal-CT porcellanite }\end{array}$ & $\begin{array}{l}\text { Laminated clay-Fe-oxide- } \\
\text { radiolarian-rich microquartz } \\
\text { containing large quartz- } \\
\text { chalcedony vein }\end{array}$ & $\begin{array}{l}\text { Quartz, } \\
\text { opal-CT }\end{array}$ & - & $\begin{array}{l}\text { Smectite, } \\
\text { illite, } \\
\text { pyrite?, } \\
\text { feldspar? }\end{array}$ & $\begin{array}{l}\text { (A) } \\
\text { (C) }\end{array}$ & $\begin{array}{l}0.9 \\
1.4\end{array}$ & $\overline{-}$ & $\begin{array}{l}4.101 \\
4.105\end{array}$ & $\begin{array}{l}77 \\
74\end{array}$ \\
\hline $464-11-1,41$ & Cenomanian & 89.4 & $\begin{array}{l}\text { Orange jasper with quartz } \\
\text { veins }\end{array}$ & $\begin{array}{l}\text { Radiolarian-bearing Fe-oxide- } \\
\text { rich microquartz containing } \\
\text { chalcedony and microquartz } \\
\text { veins }\end{array}$ & Quartz & - & $\begin{array}{l}\text { Opal-CT, } \\
\text { feldspar? }\end{array}$ & (A) & - & 1.24 & - & - \\
\hline $464-14-1,10$ & Cenomanian & 117.6 & $\begin{array}{l}\text { Gray quartz-opal-CT por- } \\
\text { cellanite; siliccous chalk }\end{array}$ & $\begin{array}{l}\text { Radiolarian-rich microquartz; } \\
\text { chalk with microquartz filled } \\
\text { radiolarians }\end{array}$ & Quartz & $\begin{array}{l}\text { Opal-CT, } \\
\text { calcite }\end{array}$ & Smectite & $\begin{array}{l}\text { (C) } \\
\text { (B) }\end{array}$ & $\begin{array}{l}5.3 \\
2.0\end{array}$ & $<-$ & $\begin{array}{l}4.107 \\
4.103\end{array}$ & $\begin{array}{l}66 \\
76\end{array}$ \\
\hline $464-14-1,40$ & Cenomanian & 117.9 & $\begin{array}{l}\text { Gray chert with pyrite filled } \\
\text { burrows }\end{array}$ & $\begin{array}{l}\text { Microquartz with pyrite } \\
\text { cubes and opal- } \\
\text { CT-clay-pyrite } \\
\text { filled burrows }\end{array}$ & Quartz & Pyrite & Smectite & (A) & - & 1.19 & - & - \\
\hline $464-17, \mathrm{CC}$ & $\begin{array}{l}\text { Albian to } \\
\text { Cenomanian }\end{array}$ & 146.0 & $\begin{array}{l}\text { Orange jasper with } \\
\text { calcareous quartz } \\
\text { porcellanite rims } \\
\text { and burrows }\end{array}$ & $\begin{array}{l}\text { Radiolarian-Fe-oxide-rich } \\
\text { microquartz with } \mathrm{Fe} \text {-stained } \\
\text { burrows rimmed } \\
\text { with clean } \\
\text { microquartz }\end{array}$ & Quartz & Calcite & $\begin{array}{l}\text { Illite, } \\
\text { smectite }\end{array}$ & $\begin{array}{l}\text { (A) } \\
\text { (A) } \\
\text { (C) }\end{array}$ & $\bar{z}$ & $\begin{array}{l}3.34^{\mathrm{d}} \\
0.88^{\mathrm{e}} \\
4.18\end{array}$ & $\bar{z}$ & $\bar{z}$ \\
\hline $464-25-1,39$ & $\begin{array}{l}\text { Early } \\
\text { Albian }\end{array}$ & 222.4 & $\begin{array}{l}\text { Orange jasper, with cal- } \\
\text { careous quartz porcellanite } \\
\text { burrows }\end{array}$ & - & Quartz & - & Calcite & (A) & - & 0.45 & - & - \\
\hline $464-25-1,72$ & $\begin{array}{l}\text { Early } \\
\text { Albian }\end{array}$ & 222.7 & $\begin{array}{l}\text { Orange jasper, with cal- } \\
\text { careous quartz porcellanite } \\
\text { burrows }\end{array}$ & - & Quartz & - & $\begin{array}{l}\text { Calcite, } \\
\text { smectite }\end{array}$ & $\begin{array}{l}\text { (A) } \\
\text { (C) }\end{array}$ & $\overline{-}$ & $<1$ & $\overline{-}$ & $\overline{-}$ \\
\hline $464-27-1,23$ & $\begin{array}{l}\text { Early } \\
\text { Albian }\end{array}$ & 241.2 & $\begin{array}{l}\text { Orange jasper, with cal- } \\
\text { careous quartz porcellanite } \\
\text { burrows }\end{array}$ & H- & Quartz & - & $\begin{array}{l}\text { Calcite, } \\
\text { feldspar? }\end{array}$ & (A) & - & 1.16 & - & - \\
\hline $464-29 \cdot 1,65$ & $\begin{array}{l}\text { Early } \\
\text { Cretaceous }\end{array}$ & 260.7 & $\begin{array}{l}\text { Brown chert; brown quartz } \\
\text { porcellanite }\end{array}$ & $\begin{array}{l}\text { Hematite-radiolarian-rich } \\
\text { microquartz }\end{array}$ & Quartz & - & $\begin{array}{l}\text { Smectite, } \\
\text { hematite, } \\
\text { illite?, } \\
\text { feldspar?, } \\
\text { barite? }\end{array}$ & $\begin{array}{l}\text { (A) } \\
\text { (C) }\end{array}$ & $\overline{-}$ & $<\begin{array}{l}0.90 \\
<1\end{array}$ & $\overline{-}$ & $\overline{-}$ \\
\hline $464-29-1,138$ & $\begin{array}{l}\text { Early } \\
\text { Cretaceous }\end{array}$ & 261.4 & $\begin{array}{l}\text { Laminated dark-and } \\
\text { medium-brown chert }\end{array}$ & $\begin{array}{l}\text { Extensively burrowed } \\
\text { laminated hematite-radio- } \\
\text { larian-rich microquartz }\end{array}$ & Quartz & - & $\begin{array}{l}\text { Chlorite, } \\
\text { smectite, } \\
\text { illite, } \\
\text { hematite }\end{array}$ & $\begin{array}{l}\text { (A) } \\
\text { (A) }\end{array}$ & $\overline{-}$ & $<1^{4} f^{18^{c}}$ & $\overline{-}$ & $\overline{-}$ \\
\hline $464-33-1,14$ & $\begin{array}{l}\text { Early } \\
\text { Cretaceous }\end{array}$ & 298.1 & $\begin{array}{l}\text { Laminated brown and red } \\
\text { chert }\end{array}$ & - & Quartz & - & Smectite & $\begin{array}{l}\text { (A) } \\
\text { (A) }\end{array}$ & $\overline{-}$ & $\begin{array}{l}<1^{\mathrm{e}} \\
0.56^{\mathrm{d}}\end{array}$ & $\overline{-}$ & $\overline{-}$ \\
\hline $465-2, \mathrm{CC}$ & $\begin{array}{l}\text { Late } \\
\text { Paleocene }\end{array}$ & 9.4 & $\begin{array}{l}\text { Gray chert with quartz } \\
\text { porcellanite rim }\end{array}$ & $\begin{array}{l}\text { Clean microquartz; fora- } \\
\text { minifer bearing chalk } \\
\text { containing patches of an } \\
\text { unknown isotropic mineral }\end{array}$ & Quartz & - & $\begin{array}{l}\text { Apatite, } \\
\text { barite?, } \\
\text { dolomite?, } \\
\text { halite?. } \\
\text { jarosite? }\end{array}$ & $\begin{array}{l}\text { (A) } \\
\text { (C) }\end{array}$ & $\overline{-}$ & $\begin{array}{l}<1 \\
0.49\end{array}$ & $\overline{-}$ & $\overline{-}$ \\
\hline $465-5-2,118$ & $\begin{array}{l}\text { Late } \\
\text { Paleocene }\end{array}$ & 32.2 & $\begin{array}{l}\text { Gray chert; quartz } \\
\text { porcellanite }\end{array}$ & - & Quartz & - & $\begin{array}{l}\text { Feldspar, } \\
\text { smectite, } \\
\text { dolomite?, } \\
\text { apatite? }\end{array}$ & $\begin{array}{l}\text { (A) } \\
\text { (C) }\end{array}$ & $\overline{-}$ & $\begin{array}{l}0.87 \\
1.96\end{array}$ & $\overline{-}$ & $\overline{-}$ \\
\hline $465 \mathrm{~A}-2, \mathrm{CC}$ & $\begin{array}{l}\text { Early } \\
\text { Paleocene }\end{array}$ & 48.5 & $\begin{array}{l}\text { Clear chert with quartz } \\
\text { porcellanite rim }\end{array}$ & - & Quartz & - & $\begin{array}{l}\text { Feldspar, } \\
\text { smectite, } \\
\text { dolomite? }\end{array}$ & (A) & - & $<1$ & - & - \\
\hline $465 \mathrm{~A}-3-6,52$ & $\begin{array}{l}\text { Early } \\
\text { Paleocene }\end{array}$ & 66.0 & $\begin{array}{l}\text { Blue-gray chert with quartz } \\
\text { porcellanite rim }\end{array}$ & - & Quartz & - & $\begin{array}{l}\text { Calcite, } \\
\text { pyrite, } \\
\text { feldspar, } \\
\text { dolomite? }\end{array}$ & (A) & - & $<1$ & - & - \\
\hline $465 \mathrm{~A}-7-1,110$ & $\begin{array}{l}\text { Early } \\
\text { Maastrichtian }\end{array}$ & 97.1 & $\begin{array}{l}\text { Blue-gray chert with quartz } \\
\text { porcellanite burrows }\end{array}$ & $\begin{array}{l}\text { Clean microquartz with } \\
\text { opaque filled burrows }\end{array}$ & Quartz & - & $\begin{array}{l}\text { Apatite, } \\
\text { rhodocrosite }\end{array}$ & (A) & - & $<1$ & - & - \\
\hline $465 \mathrm{~A}-13-1,10$ & $\begin{array}{l}\text { Late } \\
\text { Campanian } \\
\text { to Early } \\
\text { Maastrichtian }\end{array}$ & 153.1 & $\begin{array}{l}\text { Gray chert with calcareous } \\
\text { quartz porcellanite rim }\end{array}$ & - & Quartz & Calcite & $\begin{array}{l}\text { Barite?, } \\
\text { anhydrite? }\end{array}$ & (A) & $\overline{-}$ & $<1^{0.42}$ & $\bar{z}$ & $\overline{-}$ \\
\hline $465 \mathrm{~A}-21-1,60$ & Santonian & 229.6 & $\begin{array}{l}\text { Gray chert with quartz- } \\
\text { opal-CT porcellanite rim }\end{array}$ & ath the git & Quartz & Opal-CT & $\begin{array}{l}\text { Calcite, } \\
\text { feldspar, } \\
\text { barite, } \\
\text { anhydrite?, } \\
\text { apatite? }\end{array}$ & $\begin{array}{l}\text { (A) } \\
\text { (C) }\end{array}$ & $\overline{8.1}$ & $<1^{1.14}$ & $4 . \overline{093}$ & $\overline{79}$ \\
\hline 465A-25,CC & $\begin{array}{l}\text { Late } \\
\text { Turonian } \\
\text { to Early } \\
\text { Coniacian }\end{array}$ & 267.0 & $\begin{array}{l}\text { Brown chert with quartz } \\
\text { porcellanite burrows }\end{array}$ & $\begin{array}{l}\text { Clean microquartz with } \\
\text { burrows filled with clay, } \\
\text { Fe-oxide, an unknown } \\
\text { isotropic mineral }\end{array}$ & Quartz & - & - & (A) & - & 0.20 & - & - \\
\hline $465 \mathrm{~A}-26-1,91$ & $\begin{array}{l}\text { Early } \\
\text { Cenomanian }\end{array}$ & 277.4 & Black chert & $\begin{array}{l}\text { Radiolarian-Fe-oxide-rich } \\
\text { microquartz }\end{array}$ & Quartz & - & $\begin{array}{l}\text { Illite, } \\
\text { smectite }\end{array}$ & (A) & - & 0.59 & - & - \\
\hline $465 \mathrm{~A}-34-1,112$ & $\begin{array}{l}\text { Late } \\
\text { Albian }\end{array}$ & 353.6 & Black chert & - & Quartz & - & $\begin{array}{l}\text { Calcite, } \\
\text { dolomite }\end{array}$ & (A) & - & $<1$ & - & - \\
\hline $465 \mathrm{~A}-38-2,32$ & $\begin{array}{l}\text { Late } \\
\text { Albian }\end{array}$ & 392.3 & $\begin{array}{l}\text { Black calcareous chert; } \\
\text { siliceous chalk }\end{array}$ & $\begin{array}{l}\text { Foraminifer-bearing chalk } \\
\text { containing wavy hematite } \\
\text { laminations; calcareous } \\
\text { microquartz }\end{array}$ & $\begin{array}{l}\text { Quartz, } \\
\text { calcite }\end{array}$ & - & $\begin{array}{l}\text { Apatite, } \\
\text { feldspar }\end{array}$ & (A) & - & 0.75 & - & - \\
\hline $465 \mathrm{~A}-38-2,80$ & $\begin{array}{l}\text { Late } \\
\text { Albian }\end{array}$ & 392.8 & $\begin{array}{l}\text { Black chert with gray } \\
\text { calcareous chert rim }\end{array}$ & - & Quartz & Calcite & Feldspar & $\begin{array}{l}\text { (A) } \\
\text { (B) }\end{array}$ & $\overline{-}$ & $\begin{array}{l}<1 \\
0.36\end{array}$ & $\overline{-}$ & $\overline{-}$ \\
\hline $465 \mathrm{~A}-40-1,26$ & $\begin{array}{l}\text { Late } \\
\text { Albian }\end{array}$ & 409.8 & $\begin{array}{l}\text { Black chert with gray } \\
\text { calcareous chert rim }\end{array}$ & - & Quartz & Calcite & - & $\begin{array}{l}\text { (A) } \\
\text { (B) }\end{array}$ & $\overline{-}$ & $<1$ & $\overline{-}$ & $\overline{-}$ \\
\hline $466-8-1,10$ & $\begin{array}{l}\text { Early } \\
\text { Pliocene }\end{array}$ & 65.1 & $\begin{array}{l}\text { Light-brown chert: } \\
\text { calcareous chert }\end{array}$ & - & Quartz & Calcite & $\begin{array}{l}\text { Barite, } \\
\text { pyrite, } \\
\text { rhodocrosite?, } \\
\text { gypsum? }\end{array}$ & (A) & $\overline{-}$ & $\begin{array}{l}1.25 \\
0.28\end{array}$ & $\overline{-}$ & $\overline{-}$ \\
\hline $466-9-1,64$ & $\begin{array}{l}\text { Late } \\
\text { Eocene }\end{array}$ & 75.1 & $\begin{array}{l}\text { Laminated brown and } \\
\text { gray chert }\end{array}$ & - & Quartz & - & $\begin{array}{l}\text { Barite, } \\
\text { gypsum, } \\
\text { smectite }\end{array}$ & (A) & - & $0.45^{8}$ & - & - \\
\hline $466-10, \mathrm{CC}$ & $\begin{array}{l}\text { Middle } \\
\text { Eocene }\end{array}$ & 84.0 & $\begin{array}{l}\text { Brown chert with calcareous } \\
\text { chert rim }\end{array}$ & - & $\begin{array}{l}\text { Quartz, } \\
\text { calcite }\end{array}$ & - & $\begin{array}{l}\text { Barite, } \\
\text { gypsum, } \\
\text { apatite? }\end{array}$ & $\begin{array}{l}\text { (A) } \\
\text { (B) }\end{array}$ & $\bar{z}$ & $<1_{3,14}$ & $\bar{z}$ & $\underline{-}$ \\
\hline
\end{tabular}


Table 1. (Continued).

\begin{tabular}{|c|c|c|c|c|c|c|c|c|c|c|c|c|}
\hline \multirow{3}{*}{$\frac{\text { Sample }}{463-6-6,36 \mathrm{~cm}}$} & \multirow{2}{*}{$\begin{array}{l}\text { Age of Host } \\
\text { Sediment }\end{array}$} & \multirow{2}{*}{$\begin{array}{l}\text { Sub-bottom } \\
\text { Depth } \\
(\mathrm{m})\end{array}$} & \multirow[b]{2}{*}{ Lithology } & \multirow{2}{*}{$\begin{array}{l}\text { Thin-Section } \\
\text { Lithology }\end{array}$} & \multicolumn{3}{|c|}{ General X-Ray Mineralogy } & \multirow{2}{*}{\multicolumn{2}{|c|}{$\begin{array}{l}\text { Quartz' } \\
\text { Opal-CT }\end{array}$}} & \multirow{3}{*}{$\begin{array}{c}\begin{array}{c}\text { Quartz } \\
\text { Crystallinity }\end{array} \\
0.73\end{array}$} & \multirow{3}{*}{$\begin{array}{c}\begin{array}{c}\text { Opal-CT } \\
d \text {-Spacing } \\
(\AA)\end{array} \\
-\end{array}$} & \multirow{3}{*}{$\begin{array}{c}\begin{array}{c}\text { Opal-CT } \\
\text { Crystallite } \\
\text { Size }\end{array} \\
-\end{array}$} \\
\hline & & & & & Major & Moderate & Trace & & & & & \\
\hline & $\begin{array}{l}\text { Middle } \\
\text { Eocene }\end{array}$ & 45.9 & Brown calcareous chert & - & Quartz & - & Calcite & (B) & - & & & \\
\hline $463-9-3,50$ & $\begin{array}{l}\text { Early } \\
\text { Maastrichtian }\end{array}$ & 66.0 & $\begin{array}{l}\text { Brown chert; quartz- } \\
\text { opal-CT porcellanite with } \\
\text { chalk rim }\end{array}$ & $\begin{array}{l}\text { Burrowed microquartz with } \\
\text { radiolarian ghosts and silica } \\
\text { replaced foraminifers: } \\
\text { foraminifer-radiolarian } \\
\text { bearing chalk }\end{array}$ & $\begin{array}{l}\text { Quartz, } \\
\text { calcite }\end{array}$ & - & $\begin{array}{l}\text { Opal-CT, } \\
\text { smectite }\end{array}$ & $\begin{array}{l}\text { (A) } \\
\text { (C) }\end{array}$ & $\overline{3.2}$ & $\begin{array}{l}<1 \\
1.57\end{array}$ & $4 . \overline{075}$ & $\overline{77}$ \\
\hline $463-9-3,53$ & $\begin{array}{l}\text { Early } \\
\text { Maastrichtian }\end{array}$ & 66.0 & $\begin{array}{l}\text { Brown chert with calcareous } \\
\text { quartz-opal-CT porcellanite } \\
\text { rim }\end{array}$ & - & $\begin{array}{l}\text { Quartz, } \\
\text { calcite }\end{array}$ & - & Smectite & $\begin{array}{l}\text { (A) } \\
\text { (C) }\end{array}$ & $\begin{array}{l}3.0 \\
3.4\end{array}$ & $<1^{1.82}$ & $\begin{array}{l}4.084 \\
4.090\end{array}$ & $\begin{array}{l}83 \\
78\end{array}$ \\
\hline $463-10-6,77$ & $\begin{array}{l}\text { Early } \\
\text { Maastrichtian }\end{array}$ & 80.3 & $\begin{array}{l}\text { Gray calcareous quartz- } \\
\text { opal-CT porcellanite with } \\
\text { siliceous chalk }\end{array}$ & $\begin{array}{l}\text { Calcareous quartz } \\
\text { porcellanite containing radio- } \\
\text { larian ghosts and micro- } \\
\text { quartz burrows; quartz } \\
\text { porcellanite rim; siliceous } \\
\text { chalk }\end{array}$ & $\begin{array}{l}\text { Quartz, } \\
\text { calcite }\end{array}$ & Opal-CT & Smectite & $\begin{array}{l}\text { (C) } \\
\text { (D) }\end{array}$ & $\begin{array}{l}3.2 \\
1.2\end{array}$ & $\stackrel{2.39}{-}$ & $\begin{array}{l}4.092 \\
4.090\end{array}$ & $\begin{array}{l}87 \\
83\end{array}$ \\
\hline $463-10-6,82$ & $\begin{array}{l}\text { Early } \\
\text { Maastrichtian }\end{array}$ & 80.3 & Siliceous chalk & - & Calcite & Opal-CT & Smectite & (D) & 0.8 & - & 4.077 & 75 \\
\hline $463-13-6,98$ & $\begin{array}{l}\text { Early } \\
\text { Maastrichtian }\end{array}$ & 109.0 & $\begin{array}{l}\text { Siliceous chalk with patches } \\
\text { of brown quartz-opal-CT } \\
\text { porcellanite }\end{array}$ & $\begin{array}{l}\text { Radiolarian-foraminifer- } \\
\text { bearing siliceous chalk with } \\
\text { microquartz filled burrow } \\
\text { rimmed with opal-CT }\end{array}$ & $\begin{array}{l}\text { Quartz, } \\
\text { calcite }\end{array}$ & Opal-CT & Smectite & (D) & 0.7 & $<1$ & 4.082 & 76 \\
\hline $463-16-1,48$ & $\begin{array}{l}\text { Early } \\
\text { Maastrichtian }\end{array}$ & 129.5 & $\begin{array}{l}\text { Siliceous chalk with patches } \\
\text { of gray calcareous quartz- } \\
\text { opal-CT porcellanite }\end{array}$ & - & $\begin{array}{l}\text { Quartz, } \\
\text { calcite }\end{array}$ & Opal-CT & - & $\begin{array}{l}\text { (C) } \\
\text { (D) }\end{array}$ & $\begin{array}{l}5.8 \\
0.9\end{array}$ & 1.19 & $4 . \overline{092}$ & $\overline{95}$ \\
\hline $463-22, \mathrm{CC}$ & $\begin{array}{l}\text { Late } \\
\text { Campanian }\end{array}$ & 195.4 & $\begin{array}{l}\text { Brown chert; quartz } \\
\text { porcellanite }\end{array}$ & Mierogurt containing & Quartz & - & Smectite & (A) & - & 0.74 & - & - \\
\hline $463-25-1,12$ & $\begin{array}{l}\text { Late } \\
\text { Campanian }\end{array}$ & 205.1 & $\begin{array}{l}\text { Brown chert with gray } \\
\text { calcareous quartz por- } \\
\text { cellanite back-filled burrow } \\
\text { with siliceous chalk rim }\end{array}$ & $\begin{array}{l}\text { Microquartz containing } \\
\text { radiolarian-foraminifer- } \\
\text { bearing siliceous chalk } \\
\text { burrow rimmed by clay-Fe- } \\
\text { oxide-rich laminae }\end{array}$ & $\begin{array}{l}\text { Quartz, } \\
\text { calcite }\end{array}$ & - & Smectite & $\begin{array}{l}\text { (A) } \\
\text { (C) }\end{array}$ & $\overline{-}$ & $<1,5.95$ & $\overline{-}$ & $\overline{-}$ \\
\hline $463-26-6,21$ & $\begin{array}{l}\text { Early } \\
\text { Santonian }\end{array}$ & 222.2 & Red chert & - & Quartz & - & Smectite & (A) & - & 3.34 & - & - \\
\hline $463-31-1,27$ & $\begin{array}{l}\text { Late } \\
\text { Turonian }\end{array}$ & 262.3 & $\begin{array}{l}\text { Siliceous chalk; quartz- } \\
\text { opal-CT porcellanite; } \\
\text { brown chert }\end{array}$ & - & $\begin{array}{l}\text { Quartz, } \\
\text { calcite }\end{array}$ & Opal-CT & $\begin{array}{l}\text { Smectite } \\
\text { barite?, } \\
\text { dolomite? }\end{array}$ & $\begin{array}{l}\text { (A) } \\
\text { (C) } \\
\text { (D) }\end{array}$ & $\begin{array}{l}\overline{4.0} \\
0.7\end{array}$ & $<1$. & $\begin{array}{l}4 . \overline{092} \\
4.088\end{array}$ & $\begin{array}{l}\overline{67} \\
74\end{array}$ \\
\hline $463-31, \mathrm{CC}$ & $\begin{array}{l}\text { Late } \\
\text { Turonian }\end{array}$ & 271.4 & $\begin{array}{l}\text { Brown chert; quartz- } \\
\text { opal-CT porcellanite }\end{array}$ & - & Quartz & Opal-CT & - & $\begin{array}{l}\text { (A) } \\
\text { (C) }\end{array}$ & $\bar{z}$ & 1 & $4 . \overline{098}$ & $\overline{79}$ \\
\hline $463-33-2,85$ & $\begin{array}{l}\text { Late } \\
\text { Turonian }\end{array}$ & 273.8 & $\begin{array}{l}\text { Brown chert with calcareous } \\
\text { opal-CT porcellanite rims }\end{array}$ & - & Quartz & Calcite & $\begin{array}{l}\text { Opal-CT, } \\
\text { calcite, } \\
\text { smectite, } \\
\text { apatite? } \\
\text { Smectite, }\end{array}$ & $\begin{array}{l}\text { (A) } \\
\text { (C) }\end{array}$ & $\overline{7.3}$ & $\begin{array}{l}0.68 \\
0.76\end{array}$ & $4 . \overline{075}$ & $\overline{92}$ \\
\hline $463-40, \mathrm{CC}$ & $\begin{array}{l}\text { Late } \\
\text { Cenomanian }\end{array}$ & 356.9 & $\begin{array}{l}\text { Gray chert with calcareous } \\
\text { quartz porcellanite }\end{array}$ & 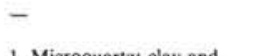 & Quartz & Calcite & $\begin{array}{l}\text { Smectite, } \\
\text { barite? }\end{array}$ & $\begin{array}{l}\text { (A) } \\
\text { (C) }\end{array}$ & $\frac{-}{36}$ & $\begin{array}{l}0.27 \\
2.61\end{array}$ & $\overline{\bar{c}}$ & $\overline{\overline{s i}}$ \\
\hline $463-45, C \mathrm{C}$ & $\begin{array}{l}\text { Late } \\
\text { Albian }\end{array}$ & 404.4 & $\begin{array}{l}\text { 1. Dark-gray chert; light- } \\
\text { gray calcareous chert }\end{array}$ & $\begin{array}{l}\text { 1. Microquartz; clay and } \\
\text { Fe-oxide-rich chalk con- } \\
\text { taining opal-CT burrows }\end{array}$ & Quartz & Calcite & - & $\begin{array}{l}\text { (A) } \\
\text { (B) }\end{array}$ & $\begin{array}{l}3.6 \\
-\end{array}$ & $\begin{array}{l}1.70 \\
2.59\end{array}$ & $\stackrel{4.088}{-}$ & -85 \\
\hline & & & $\begin{array}{l}\text { 2. Gray chert with quartz- } \\
\text { opal-CT porcellanite rims }\end{array}$ & - & Quartz & Opal-CT & $\begin{array}{l}\text { Smectite, } \\
\text { barite? }\end{array}$ & (A) & - & 0.83 & - & - \\
\hline $463-49, \mathrm{CC}$ & $\begin{array}{l}\text { Late } \\
\text { Albian }\end{array}$ & 427.5 & 1. Gray calcareous chert & - & Quartz & - & $\begin{array}{l}\text { Calcite, } \\
\text { smectite } \\
\text { Ouartz. }\end{array}$ & (B) & - & $<1$ & - & - \\
\hline $463-52, \mathrm{CC}$ & Middle & 461.4 & Gray calcareous chert & - & Quartz, & - & $\begin{array}{l}\text { Quartz, } \\
\text { smectite } \\
\text { Smectite }\end{array}$ & (B) & - & 3.52 & - & - \\
\hline $463-54, C C$ & $\begin{array}{l}\text { Albian } \\
\text { Middle } \\
\text { Albian }\end{array}$ & 471.0 & $\begin{array}{l}\text { 1. Light-brown siliceous } \\
\text { chalk with brown chert } \\
\text { nodule }\end{array}$ & $\begin{array}{l}\text { 1. Microquartz; foraminifer- } \\
\text { radiolarian-bearing } \\
\text { opal-CT and microquartz; } \\
\text { chalk rim }\end{array}$ & $\begin{array}{l}\text { calcite } \\
\text { Calcite, } \\
\text { quartz }\end{array}$ & - & - & (D) & - & 2.07 & - & - \\
\hline & & & $\begin{array}{l}\text { 2. Light-brown chert with } \\
\text { quartz porcellanite rim }\end{array}$ & - & Quartz & & & (A) & - & 1.29 & - & - \\
\hline $463-59-1,38$ & $\begin{array}{l}\text { Early } \\
\text { Albian }\end{array}$ & 518.9 & $\begin{array}{l}\text { Siliceous chalk with gray } \\
\text { calcareous chert rim }\end{array}$ & - & $\begin{array}{l}\text { Quartz, } \\
\text { calcite }\end{array}$ & - & Dolomite & (B) & - & 1.55 & - & - \\
\hline 463-59-1, 109 & $\begin{array}{l}\text { Early } \\
\text { Albian }\end{array}$ & 519.6 & $\begin{array}{l}\text { Siliceous chalk with light- } \\
\text { brown calcareous quartz- } \\
\text { opal-CT porcellanite burrow }\end{array}$ & - & $\begin{array}{l}\text { Quartz, } \\
\text { calcite }\end{array}$ & - & $\begin{array}{l}\text { Opal-CT, } \\
\text { dolomite, } \\
\text { smectite }\end{array}$ & $\begin{array}{l}\text { (B) } \\
\text { (D) }\end{array}$ & $\begin{array}{l}7.3 \\
3.8\end{array}$ & $<1$ & $\begin{array}{l}4.071 \\
4.079\end{array}$ & $\begin{array}{l}90 \\
88\end{array}$ \\
\hline $463-60-1,30$ & $\begin{array}{l}\text { Late } \\
\text { Aptian }\end{array}$ & 528.3 & $\begin{array}{l}\text { Medium- and light-brown } \\
\text { siliceous chalk with dark- } \\
\text { brown chert rim }\end{array}$ & $\begin{array}{l}\text { Radiolarian-foraminifer- } \\
\text { bearing siliceous chalk con- } \\
\text { taining opal-CT- microquartz } \\
\text { burrow with opal-CT-micro- } \\
\text { quartz rim }\end{array}$ & $\begin{array}{l}\text { Calcite, } \\
\text { quartz }\end{array}$ & - & Feldspar? & $\begin{array}{l}\text { (A) } \\
\text { (D) } \\
\text { (D) }\end{array}$ & $\bar{z}$ & $\begin{array}{l}0.38 \\
6.19^{\mathrm{b}} \\
2.15^{\mathrm{c}}\end{array}$ & $\bar{z}$ & $\overline{-}$ \\
\hline $463-60-1,82$ & $\begin{array}{l}\text { Late } \\
\text { Aptian }\end{array}$ & 528.8 & $\begin{array}{l}\text { Light-red siliceous chalk; } \\
\text { dark-red calcareous chert }\end{array}$ & $\begin{array}{l}\text { Radiolarian-foraminifer- } \\
\text { bearing clay and } \mathrm{Fe} \text {-oxide- } \\
\text { rich micrite with quartz and } \\
\text { opal-CT burrows }\end{array}$ & $\begin{array}{l}\text { Quartz, } \\
\text { calcite }\end{array}$ & - & - & $\begin{array}{l}\text { (B) } \\
\text { (D) }\end{array}$ & $\overline{-}$ & $\begin{array}{l}2.71 \\
0.57\end{array}$ & $\bar{z}$ & $\overline{-}$ \\
\hline $463-69-1,74$ & $\begin{array}{l}\text { Early } \\
\text { Aptian }\end{array}$ & 604.7 & $\begin{array}{l}\text { Gray calcareous chert with } \\
\text { brown chert rim }\end{array}$ & $\begin{array}{l}\text { Clay-radiolarian-rich chalk; } \\
\text { microquartz containing pyrite } \\
\text { and calcite-filled radiolarians. }\end{array}$ & Quartz & Calcite & - & $\begin{array}{l}\text { (A) } \\
\text { (B) }\end{array}$ & $\overline{-}$ & $\begin{array}{l}0.56 \\
1.20\end{array}$ & $\overline{-}$ & - \\
\hline $463-81-2,3$ & $\begin{array}{l}\text { Late } \\
\text { Barremian }\end{array}$ & 712.0 & $\begin{array}{l}\text { Laminated gray and white } \\
\text { calcareous chert }\end{array}$ & $\begin{array}{l}\text { Laminated radiolarian-rich } \\
\text { chalk and radiolarian-bearing } \\
\text { microquartz }\end{array}$ & Quartz & Calcite & $\begin{array}{l}\text { Dolomite, } \\
\text { smectite }\end{array}$ & (B) & - & 1.86 & - & - \\
\hline $463-81, C C$ & $\begin{array}{l}\text { Late } \\
\text { Barremian }\end{array}$ & 712.6 & $\begin{array}{l}\text { Laminated gray calcareous } \\
\text { chert and siliceous chalk }\end{array}$ & $\begin{array}{l}\text { Laminated radiolarian-rich } \\
\text { chalk and microquartz with } \\
\text { microquartz-opal-CT-chalk } \\
\text { transition zones }\end{array}$ & $\begin{array}{l}\text { Quartz, } \\
\text { calcite }\end{array}$ & - & Smectite & $\begin{array}{l}\text { (B) } \\
\text { (D) }\end{array}$ & $\overline{-}$ & $\begin{array}{l}0.70 \\
0.87\end{array}$ & $\overline{-}$ & $\overline{-}$ \\
\hline $463-89-1,35$ & $\begin{array}{l}\text { Late } \\
\text { Barremian }\end{array}$ & 784.9 & $\begin{array}{l}\text { Siliceous chalk with gray } \\
\text { calcareous chert rim }\end{array}$ & $\begin{array}{l}\text { Radiolarian-rich chalk con- } \\
\text { taining calcareous back-filled } \\
\text { burrow with microquartz } \\
\text { laminae; microquartz con- } \\
\text { taining calcareous and clay } \\
\text { debris }\end{array}$ & $\begin{array}{l}\text { Quartz, } \\
\text { calcite }\end{array}$ & - & Smectite & $\begin{array}{l}\text { (B) } \\
\text { (D) }\end{array}$ & $\overline{-}$ & $\begin{array}{l}1.28 \\
1.73\end{array}$ & $\overline{-}$ & $\overline{-}$ \\
\hline $464-10-3,70$ & $\begin{array}{l}\text { Late } \\
\text { Cretaceous }\end{array}$ & 83.2 & White chert & - & Quartz & - & Opal-CT & (C) & 6.1 & 1.00 & 4.105 & 77 \\
\hline $464-10-4,34$ & $\begin{array}{l}\text { Late } \\
\text { Cretaceous }\end{array}$ & 84.3 & $\begin{array}{l}\text { Dark-brown chert; quartz- } \\
\text { opal-CT porcellanite }\end{array}$ & - & Quartz & - & $\begin{array}{l}\text { Opal-CT, } \\
\text { smectite, } \\
\text { calcite }\end{array}$ & (C) & 9.0 & $<1$ & 4.084 & 76 \\
\hline $464-10-4,91$ & $\begin{array}{l}\text { Late } \\
\text { Cretaceous }\end{array}$ & 84.9 & $\begin{array}{l}\text { Dark-brown chert with } \\
\text { quartz-opal-CT porcellanite } \\
\text { rims }\end{array}$ & - & $\begin{array}{l}\text { Quartz, } \\
\text { opal-CT }\end{array}$ & - & - & $\begin{array}{l}\text { (A) } \\
\text { (C) }\end{array}$ & $\overline{1.9}$ & $\begin{array}{l}<1 \\
<1\end{array}$ & $4 . \overline{093}$ & $\overline{87}$ \\
\hline
\end{tabular}


Table 1. (Continued).

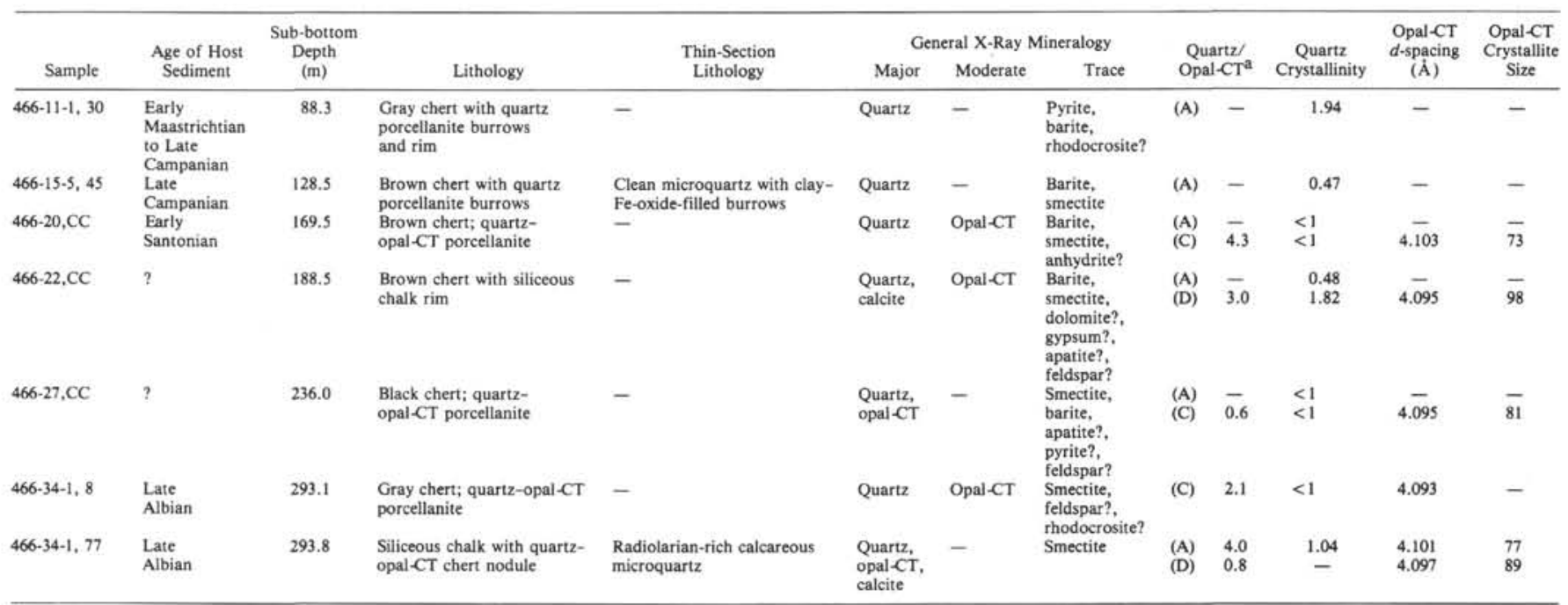

${ }_{\mathrm{b}} \mathrm{A}=$ chert and jasper; $\mathrm{B}=$ calcareous chert $\mathrm{C}=$ porcellanite; $\mathrm{D}=$ siliceous chalk.

b Light brown.

c Medium brown.

d Red.

f Brown.

$B$ Brown and gray.

other than barite. Most chert samples are devoid of significant quantities of terrigenous and volcanogenic components.

In the few studies of marine cherts that considered quartz crystallinity, no systematic changes with age or sub-bottom depth were found (Hathaway, 1972; Murata and Norman, 1976; Riech and von Rad, 1979). Crystallinity does however seem to reflect the degree of metamorphism or tectonism to which a chert has been subjected (Murata and Norman, 1976). On Murata and Norman's (1976) scale of 10, most Leg 62 cherts fall below 1 (Fig. 3), thereby indicating the poor crystallinity (equivalent to very small grain size) typical of diagenetic quartz. Variations in quartz crystallinity are not obviously related either to depth or age; however, when all samples from the four sites are considered together there is a poorly defined trend indicating that older cherts have a greater tendency to have better crystallinity than do younger ones (Fig. 3).

Opal-CT $d$-spacings decrease with depth (increasing temperature) and with time in siliceous sections on land and below the sea bed along continental margins (Murata and Nakata, 1974; Mitsui, 1975; Hein et al., 1978). Similar relationships between crystal structure and depth have not been noted in abyssal oceanic basin deposits. In Leg 62 deposits, opal-CT occurs in porcellanites formed in deposits 65 to $108 \mathrm{~m}$.y. old and at subbottom depths of 65 to 520 meters. Quartz cherts occur both above and below this depth range. Opal-CT shows a wide variation in both $d$-spacing and crystallite size, neither of these two crystallographic parameters varying systematically with age of the enclosing sediment; however, when all samples from Leg 62 sites are considered, results indicate a poorly defined trend for smaller $d$-spacings and larger crystallite sizes with depth
(Fig. 3). In addition, at Site 463, opal-CT occurring without calcite is less ordered (has a higher $d$-spacing, averaging $4.098 \AA$ ) than opal-CT associated with calcite (4.084 $\AA$; standard deviation $0.007 \AA$ ).

These observations suggest that, at least in a general way, depth of burial and the presence of calcite promote the ordering in the opal-CT crystal structure which allows its eventual conversion to quartz. This suggestion is further supported by the average of $d$-spacing values at each site. Opal-CT $d$-spacings in the carbonate section at Site 463 , which contains the stratigraphically deepest opal-CT, average $4.085 \AA$ (standard deviation $0.008 \AA$ ), whereas values at clay-rich Site 464 , where opal-CT occurs at stratigraphically shallower depths, the average $d$-spacing is $4.099 \AA$ (standard deviation $0.007 \AA$ ). Similarly, values in the shallow carbonate section at Site 466 average $4.097 \AA$ (standard deviation $0.004 \AA$ ).

The range of $d$-spacings of opal-CT in cherts and porcellanites determined in other studies is 4.040 to $4.120 \AA$ (Murata and Nakata, 1974; Hein et al., 1978), but in Miocene Monterey Formation cherts, opal-CT reaches a minimum $d$-spacing of about $4.07 \AA$ before converting to quartz (Pisciotto, 1978); for porcellanite, however, conversion to quartz should occur between 4.04 and $4.07 \AA$. The $d$-spacings for Leg 62 porcellanites range from 4.071 to $4.107 \AA$. Because there are no values less than $4.07 \AA$, and because abundant quartz porcellanites occur in Leg 62 deposits, opal-CT in Leg 62 porcellanites probably reached a minimum $d$-spacing of $4.07 \AA$ prior to quartz conversion, as in Monterey chert.

Quartz/opal-CT ratios and quartz crystallinity were measured on a fine scale through some selected samples of chert beds and porcellanite rims, to determine 

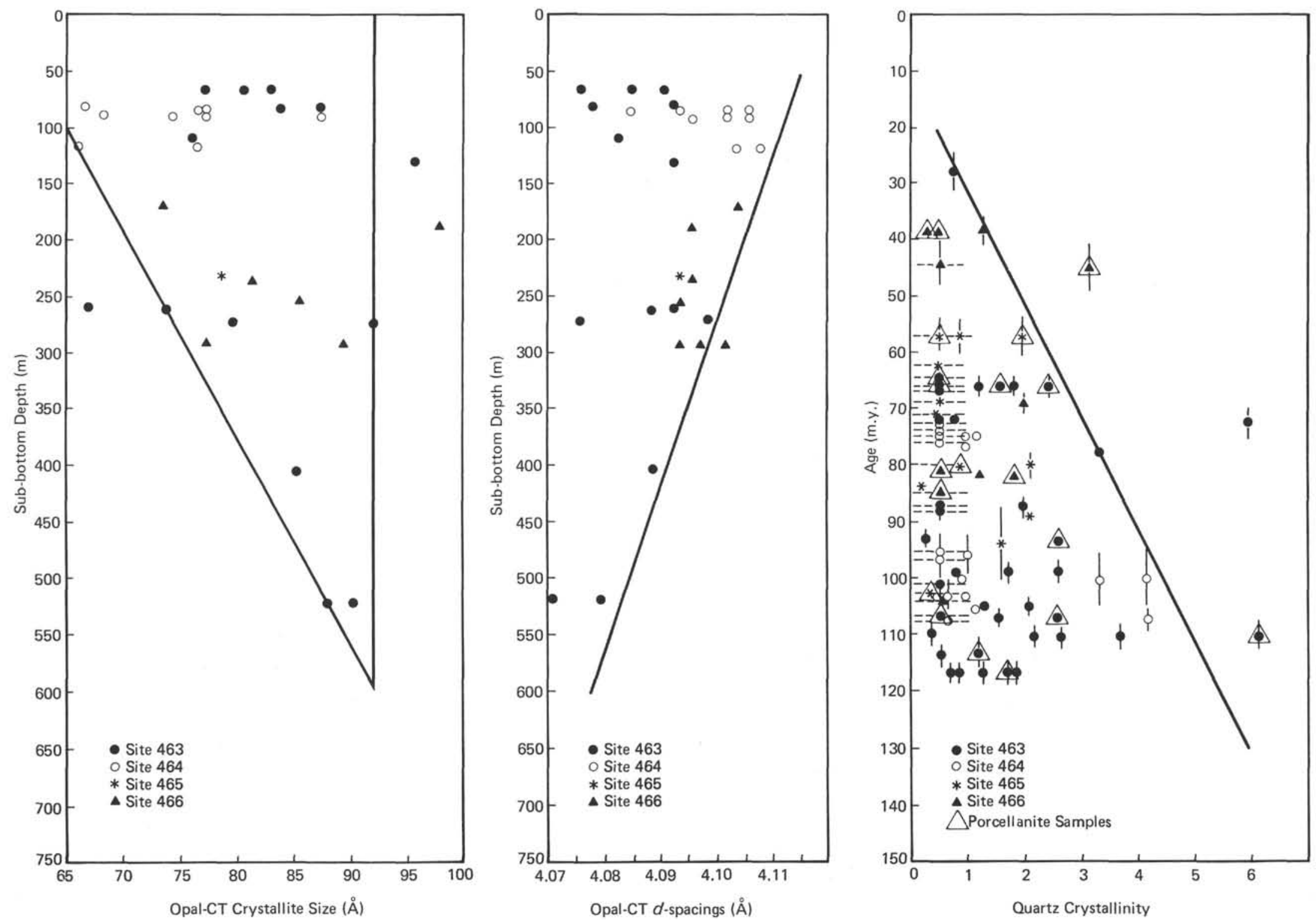

Figure 3. Variations of opal-CT crystallite sizes and $d$-spacings with depth and quartz crystallinity with age, in DSDP Leg 62 siliceous rocks. These three plots shown tendencies, albeit poorly defined ones, for larger opal-CT crystallite sizes and smaller opal-CT $d$-spacings with depth, and for greater quartz crystallinity with age. Opal-CT crystallite sizes and $d$-spacings vary randomly with age of enclosing sediment, and quartz crystallinity varies randomly with depth of occurrence. 
whether there are progressive changes from the edges to the centers. In the five studied samples (Table 3), opalCT ends abruptly at the edge of the bed and only occurs in the porcellanite rim. Quartz/opal-CT ratios are similar in porcellanite rims from either side of chert beds, and there is no apparent consistent pattern in quartz crystallinity across the beds. Of the five samples tested, only one (463-33-2, $85 \mathrm{~cm}$ ) shows an increase in crystallinity from the edge to the center of the bed, which suggests inward maturation of silica (Table 3 ). However, it is not clear why the porcellanite rim has a higher crystallinity value, and the data are not sufficient to draw any general conclusions from this crystallinity pattern.

\section{THIN-SECTION AND SEM PETROGRAPHY}

Leg 62 siliceous rocks are petrographically similar to those associated with calcareous rocks described from other DSDP Pacific sites (Heath and Moberly, 1971; Lancelot, 1973; and Keene, 1975), and details of the common features described in those reports will not be covered here. In general, porcellanites consist of silica that replaced carbonate debris, including nannofossils, foraminifers, and anhedral-granular fragments. These rocks are porous, and all gradations from chalk to completely silicified chalk (porcellanite) are found. Most commonly, the chalk is extensively replaced by silica only within millimeters of contacts with chert.

An aspect rarely emphasized in previous studies is the wholesale replacement of nannofossils by silica in porcellanite without destruction of test ornamentation (Plate 6, Fig. 2). Well preserved quartz-replaced nannofossils indicate a fine-scale replacement mechanism. Within less than a millimeter of the chert, silica (mainly quartz in Leg 62 rocks) recrystallized (by solution-precipitation and/or grain growth mechanisms) and de-

Table 3. Quart/opal-CT ratios and quartz crystallinity for porcellanite-chert beds of DSDP Leg 62.

\begin{tabular}{|c|c|c|c|c|}
\hline Sample & & $\begin{array}{l}\text { Description and Approximate } \\
\text { Location in Sample }\end{array}$ & $\begin{array}{l}\text { Peak } \\
\text { Heights }\end{array}$ & $\begin{array}{l}\text { Crystallinity } \\
\text { Index* }\end{array}$ \\
\hline $463-33-2,85 \mathrm{~cm}$ & $\begin{array}{l}11 \\
\# 2 \\
113 \\
114\end{array}$ & $\begin{array}{l}\text { Porcellanite rim } \\
\text { Brown chert }-21 / 2-\text { mm wide, next to } \# 1 \\
-21 / 2-\text { mm wide, next to } \# 2 \\
-21 / 2 \text {-mm wide, next to } \# 3\end{array}$ & $\begin{array}{l}12.4 \\
= \\
=\end{array}$ & $\begin{array}{l}0.77 \\
0.60 \\
0.67 \\
0.92\end{array}$ \\
\hline $463-45, C C$ & $\begin{array}{l}11 \\
112 \\
133 \\
H 4\end{array}$ & $\begin{array}{l}\text { White porcellanite rim sample } \sim 2-\mathrm{mm} \text { thick } \\
\text { Light -gray chert }-21 / 2-\mathrm{mm} \text { wide, next to } \# 1 \\
-11 / 2-\mathrm{mm} \text { wide, next to } \# 2 \\
-2-\mathrm{mm} \text { wide, next to } \# 3\end{array}$ & $\begin{array}{r}6.3 \\
67.0 \\
- \\
-\end{array}$ & $\begin{array}{c}0.88 \\
<1 \\
0.49 \\
0.47\end{array}$ \\
\hline $464-10-4,34 \mathrm{~cm}$ & $\begin{array}{l}172 \\
13 \\
74 \\
14\end{array}$ & $\begin{array}{l}\text { White-yellow porcellanite rim, sample } \\
-21 / 2 \text {-mm wide taken next to chert contact } \\
\text { Brown chert }-2 \text {-mm wide, next to } \# 1 \\
-2 \text {-mm wide, next to } \# 2 \\
-2 \text {-mm wide, next to } \# 3 \\
\text { Taken from an area in sample } 10 \mathrm{~mm} \\
\text { from contact }\end{array}$ & $\begin{array}{l}18.5 \\
= \\
=\end{array}$ & $\begin{array}{l}0.51 \\
<1 \\
0.36 \\
<1 \\
0.16\end{array}$ \\
\hline $464-10-4,91 \mathrm{~cm}$ & $\begin{array}{l}\# 1 \\
\# 2 \\
\# 3 \\
\# 4 \\
\# 5\end{array}$ & $\begin{array}{l}\text { White-yellow porcellanite rim }-2 \text {-mm wide } \\
\text { Brown-black chert }-2 \text {-mm wide, next to } \# 1 \\
\text { Reddish-brown chert }-21 / 2 \text {-mm wide, next to } \# 2 \\
\text { Brown chert }-11 / 2 \text {-mm wide, next to } \# 3 \\
\text { White-yellow porcellanite rim }-1 \text {-mm thick, } \\
\text { next to } \# 4 \text {, opposite } \# 1\end{array}$ & $\begin{array}{l}13.9 \\
\overline{-} \\
\overline{13.3}\end{array}$ & $\begin{array}{c}0.72 \\
<1 \\
0.22 \\
<1\end{array}$ \\
\hline $466-22, \mathrm{CC}$ & 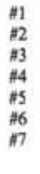 & $\begin{array}{l}\text { White porcellanite rim }-11 / 2-m m \text { wide } \\
\text { Brown chert }-11 / 2-m m \text { wide, next to } \# 1 \\
\sim 21 / 2-3-m m \text { wide, next } \# 2 \\
\sim 21 / 2-m m \text { wide, next to } \# 3 \\
-1-\text { mm wide, next to } \# 4 \\
-11 / 2-m m \text { wide, next to } \# 5 \\
\text { White porcellanite rim } 1-m \text {-mm wide, on opposite } \\
\text { side of sample from rim } \# 1\end{array}$ & $\begin{array}{l}3.8 \\
= \\
= \\
\overline{5}\end{array}$ & $\begin{array}{l}0.67 \\
<1 \\
0.66 \\
0.42 \\
<1 \\
<1 \\
<1\end{array}$ \\
\hline
\end{tabular}

- From Murata and Norman (1976). stroyed the remainders of nannofossils and any other carbonate precursor, except for some foraminifers that remain recognizable in the chert until a second stage of recrystallization or crystal growth occurred (Plates 5; 6, Fig. 5; 7, Fig. 6; 8, Figs. 1, 2). Thus, porcellanites and cherts are replaced carbonates, and the boundary between the two is most commonly sharp, whereas the boundary between the chalk and porcellanite is commonly gradational on a scale of millimeters to centimeters (Plates 4, Fig. 2; 5, Figs. 1, 4; 12, Figs. 5, 6). As noted in other works, a zone rich with inclusions of iron oxides, clays, and perhaps organic matter commonly occurs within the opal-CT transition rim, or separates the opal-CT porcellanite from the chert (Plates 4, Fig. 2; 12, Figs. 5, 6).

Cherts consist mainly of interlocking grains of microcrystalline quartz, with traces of carbonate and iron oxides in many samples. The grain sizes of quartz in cherts range from less than 0.3 to $10 \mu \mathrm{m}$, the most common sizes being 0.5 to $4 \mu \mathrm{m}$. In contrast, quartzgrain sizes within radiolarian tests range from 1 to 40 $\mu \mathrm{m}, 8$ to $12 \mu \mathrm{m}$ being most common. The most common chert texture is featureless microcrystalline quartz with circular areas of coarser-grained quartz that represent recrystallized radiolarians and radiolarian ghosts (Plates 4, Figs. 5, 6; 6, Fig. 6), but a wide variety of unusual cherts were viewed with the SEM and in thin sections (Plates 13-15).

Textural variations in both cherts and porcellanite result from different amounts of porosity, the nature of the precursor carbonate, the presence of authigenic minerals, and the degree and rate of silicification. For example, note the textural differences of a chert (Plate 15) formed from silica replacement of a carbonate that contained authigenic sulfate minerals, compared to a chert formed from replacement of a carbonate without authigenic minerals (Plate 5). Note also the contrasting textures of porcellanite in Plate 5; the different textures probably resulted from different abundances of radiolarians in the two chalks that were replaced by silica. Some cherts are peppered with pyrite ranging in size from less than a micrometer to large cubes up to a millimeter (Plate 8, Figs. 3, 4). Phosphatic fish debris is common in some cherts.

Well-preserved burrows are common in chalk, porcellanite, and chert (volume frontispiece; Plates 1-4, Figs. 1-3). In chalk, burrows are replaced by opal-CT or quartz and are more dense and less porous than the host rock (Plates 1, Figs. 1, 2; 3, Figs. 1, 2). Burrows have a similar texture and mineralogy in porcellanite and quartz porcellanite (Table 2). Identification of burrow morphologies listed in Table 2 were made by comparisons with drawings and photographs illustrated by van der Lingen (1973), Warme et al. (1973), Nilsen (1976), and Ekdale (1977, 1978).

The stratigraphically highest chert at Site 463 , which was easily removed from the chalk host rock, is a quartz-replaced burrow. In chert samples, burrows are distinguished by coarser-grained quartz or by areas with more or less inclusions of non-quartz debris than in the host chert (Plates 2; 3; 4, Figs. 1, 2). Burrow-silica 
maturation is always one step ahead of host-rock silicification, so that in chalk burrows are opal-CT or quartz, in porcellanite burrows are quartz, and in chert burrows are commonly composed of coarser-grained quartz crystals (Plate 2); quartz that fills radiolarian tests is also commonly diagenetically more evolved than is silica in the host rock, so that the chalcedony or opal-CT that filled tests in the chalk may become coarse-grained microquartz in chert (Plates 4, Figs. 4, 5; 6, Fig. 6).

Burrows may be inclusion-free, or contain more microfossils, clays, iron oxides, sulfides, and other debris than the host chert (Plates 3, Figs. 5, 6; 4, Figs. 1-3); burrows thus may be lighter or darker in color than the host rock, mostly because of iron staining. Many burrows are rimmed with opal-CT, hematite, or quartz that is relatively clean, free of iron oxides, and in some cherts finer-grained than surrounding quartz (Plates 2, Figs. 1, 2; 3, Figs. 5, 6; 4, Figs. 1-3; volume frontispiece). One backfilled burrow (frontispiece, A, B) is at the boundary between chert and siliceous chalk and is composed mostly of fine-grained calcite, except for the thin concave laminae that define the backfilling, which are composed of opal-CT.

Extensively burrowed laminae characterize several chert and jasper samples (Fig. 4; Plates 1, Figs. 3-5; 3, Figs. 3, 4). Most cherts and porcellanites are massive, although about $10 \%$ are laminated. Laminations are commonly wavy, irregular, or discontinuous as the result of burrowing (Plate 1). A few porcellanites show normal grading in size, but grading is more commonly the result of variation in microfossil abundance within a single lamina. Laminations result from alternations of radiolarian-rich and -poor layers and from variations in clay and iron oxide contents.

Microfossils, mostly radiolarians and foraminiferswhether in chalk or chert-can be either filled with or replaced by calcite, opal-CT, and (or) quartz (Plates 4-11; Table 4). All combinations of these three minerals are present, sometimes within a single thin section (Table 4; 466-34-1, $77 \mathrm{~cm}$ ), attesting to the importance of micro-environments in controlling the removal, transport, and precipitation of calcite and silica. In some foraminifer tests, adjacent chambers are filled with different minerals (Plates 5, Fig. 3; 6, Fig. 1). Quartz and chalcedony can occur within a single radiolarian test (Plate 4, Fig. 5). Opal-CT lepispheres were replaced by quartz or chalcedony within many microfossils; the bladed structure typical of opal-CT was transformed into massive spheres or spheres composed of rod-shaped quartz crystals (Plates 5, Figs. 4, 5; 6, Fig. 4; 7, Figs. 5, 6; 8, Figs. 1, 2).

The replacement of opal-CT lepispheres by quartz is inferred from rocks that show progressively less opalCT (as determined by X-ray diffraction) and also show progressively less-well-developed bladed silica spheres as seen with the SEM; the bladed spheres give way gradually (a series of intermediate forms are seen) to massive spheres or spheres composed of rod-shaped crystals. Less commonly, microfossils either were replaced by (and filled with) iron oxides, sulfides, zeolites,

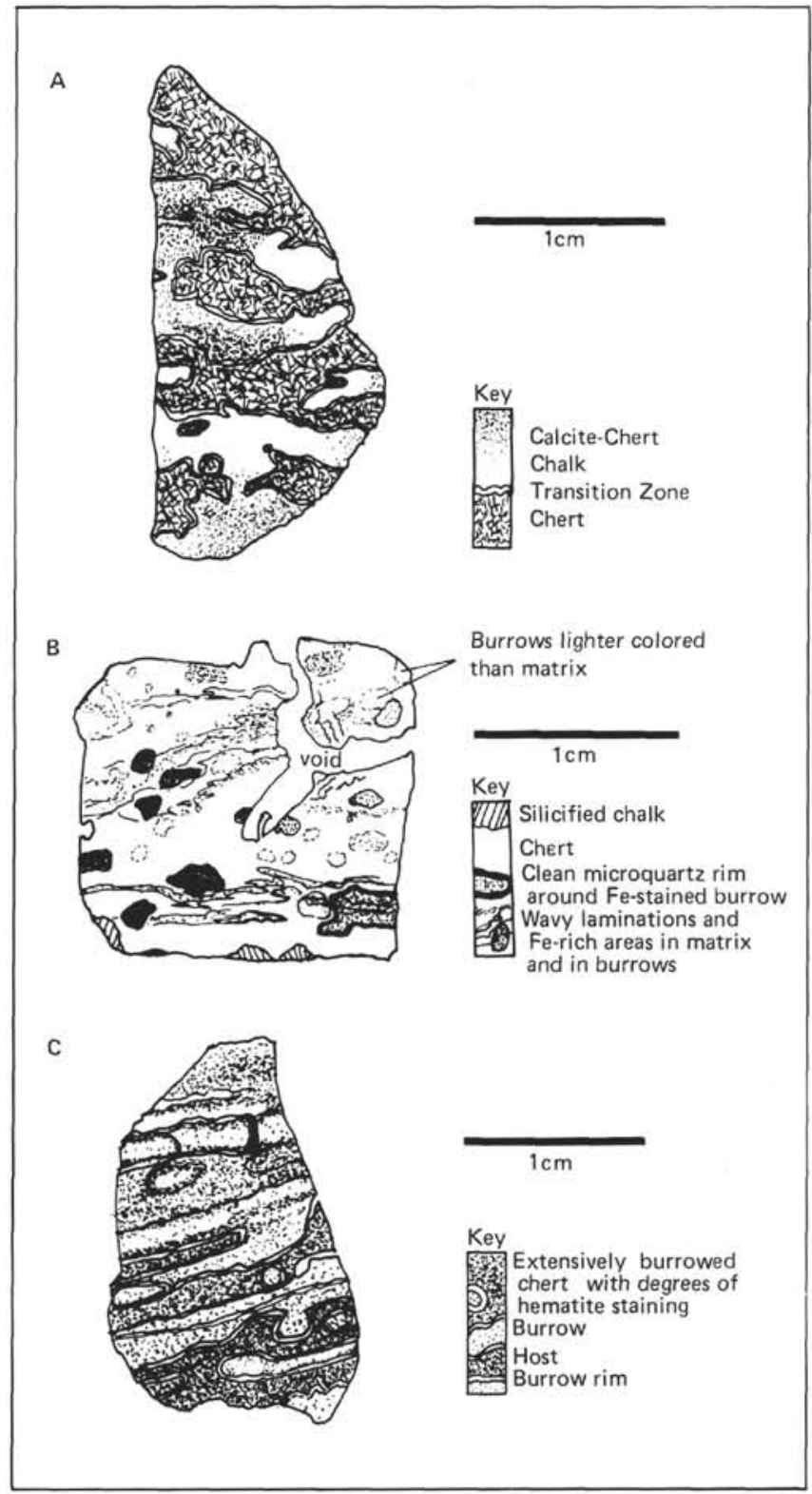

Figure 4. Illustrations of thin sections that show well-defined multiple stages of burrowing. A. 463-81,CC; highly burrowed, dark-gray, calcareous chert, interbedded with white chert (see Plates 1 and 3). Chert burrows are rimmed by a 0.1 to 0.15 - $\mathrm{mm}$ thick rim, composed mainly of quartz, that is finer-grained than in the chert. The stippled parts of the chalk are partly silicified. B. 464-17,CC; highly burrowed red-orange to red-brown jasper. See the frontispiece for photomicrographs of burrows in this jasper. C. 464-29-1, $138 \mathrm{~cm}$; highly burrowed, brown radiolarian chert (Plate 1). Staining by hematite is highest in the host chert, interbedded in the burrows, and least in the burrow rim.

or apatite (Plates 4, Fig. 6; 9, Figs. 1, 2; 10, Figs. 1, 2), or were filled with fine-grained calcareous mud.

Veins composed of microquartz or quartz and chalcedony cut some cherts (Plate 12, Figs. 3, 4). Several generations of silica characterize large veins, which are probably fillings of once-open fractures. Precipitation in void space is indicated in some cherts by a coarsening 
Table 4. Diagenetic characteristics of radiolarians and foraminifers.

\begin{tabular}{|c|c|c|c|c|c|c|c|}
\hline \multirow[b]{2}{*}{ Sample } & \multirow[b]{2}{*}{ Host Rock } & \multicolumn{3}{|c|}{ Radiolarians } & \multicolumn{3}{|c|}{ Foraminifers } \\
\hline & & Tests & Filling & Remarks & Tests & Filling & Remarks \\
\hline $464-6-6,36 \mathrm{~cm}$ & Brown chert & $\begin{array}{l}\text { Quartz (most) } \\
\text { opal-A (rare) }\end{array}$ & Quartz & & & & \\
\hline $463-9-3,50$ & Brown chert & Calcite & $\begin{array}{l}\text { Chalcedony, quartz, } \\
\text { opal-CT, calcite, } \\
\text { zeolite? }\end{array}$ & & $\begin{array}{l}\text { Quartz, opal-CT, } \\
\text { calcite? }\end{array}$ & $\begin{array}{l}\text { Quartz, opal-CT, } \\
\text { chalcedony, } \\
\text { Fe-oxides, zeolites }\end{array}$ & \\
\hline $463-10-6,77$ & $\begin{array}{l}\text { Quartz-opal-CT } \\
\text { calcareous } \\
\text { porcellanite }\end{array}$ & $\begin{array}{l}\text { Quartz, opal-CT, } \\
\text { quartz ghosts in } \\
\text { burrow, calcite }\end{array}$ & $\begin{array}{l}\text { Quartz and (or) } \\
\text { opal-CT and (or) } \\
\text { calcite }\end{array}$ & & $\begin{array}{l}\text { Recrystallized calcite } \\
\text { (most) opal-CT }\end{array}$ & $\begin{array}{l}\text { Opal-CT, large } \\
\text { calcite grains } \\
\text { sediment-filled in } \\
\text { burrows }\end{array}$ & \\
\hline \multirow[t]{3}{*}{$463-13-6,98$} & Siliceous chalk & $\begin{array}{l}\text { 1. Chert burrow: } \\
\text { quartz ghosts }\end{array}$ & 1. Quartz-chalcedony & & $\begin{array}{l}\text { 1. Chert burrows: } \\
\text { quartz ghosts }\end{array}$ & 1. Quartz & \\
\hline & & $\begin{array}{l}\text { 2. Porcellanite: } \\
\text { quartz }\end{array}$ & 2. Quartz & & $\begin{array}{l}\text { 2. Porcellanite } \\
\text { quartz, opal-CT }\end{array}$ & 2. Quartz, opal-CT & \\
\hline & & $\begin{array}{l}\text { 3. Siliceous chalk: } \\
\text { calcite, no walls } \\
\text { left }\end{array}$ & 3. Quartz, opal-CT & & $\begin{array}{l}\text { 3. Siliceous chalk: } \\
\text { recrystallized } \\
\text { calcite or ghosts }\end{array}$ & $\begin{array}{l}\text { 3. Quartz, opal-CT } \\
\text { (most); one fora- } \\
\text { minifer had one } \\
\text { chamber filled } \\
\text { with calcite, one } \\
\text { with opal-CT, } \\
\text { one with opal- } \\
\text { CT and quartz, } \\
\text { and one with } \\
\text { quartz }\end{array}$ & \\
\hline \multirow[t]{3}{*}{$463-22, \mathrm{CC}$} & $\begin{array}{l}\text { Brown chert, } \\
\text { quartz porcel- } \\
\text { lanite with }\end{array}$ & $\begin{array}{l}\text { 1. Quartz } \\
\text { porcellanite: } \\
\text { mostly no walls }\end{array}$ & $\begin{array}{l}\text { 1. Opal-CT, quartz, } \\
\text { rare calcite }\end{array}$ & & $\begin{array}{l}\text { 1. Quartz porcellan- } \\
\text { ite: quartz opal- } \\
\text { CT, or no walls }\end{array}$ & 1. Opal-CT, quartz & \\
\hline & siliceous chalk & $\begin{array}{l}\text { left; quartz, } \\
\text { opal-CT }\end{array}$ & & & $\begin{array}{l}\text { 2. Brown chert: no } \\
\text { walls or quartz }\end{array}$ & 2. Quartz & \\
\hline & & $\begin{array}{l}\text { 2. Brown chert: } \\
\text { mostly no walls } \\
\text { left; quartz }\end{array}$ & $\begin{array}{l}\text { 2. Quartz-replaced } \\
\text { opal-CT blades; } \\
\text { quartz }\end{array}$ & & & & \\
\hline $463-25-1,12$ & Brown chert & Quartz ghosts & $\begin{array}{l}\text { Pyrite, quartz, } \\
\text { clay, opal-CT, } \\
\text { chalcedony, hematite, } \\
\text { zeolites; quartz- } \\
\text { replaced coccoliths }\end{array}$ & & $\begin{array}{l}\text { Quartz ghosts; } \\
\text { hematite }\end{array}$ & $\begin{array}{l}\text { Pyrite, quartz } \\
\text { hematite- } \\
\text { magnatite? }\end{array}$ & \\
\hline \multirow{2}{*}{$\begin{array}{l}463-31-1,27 \\
463-31, C C\end{array}$} & Siliceous chalk & & & & Quartz & Quartz, opal-CT & \\
\hline & $\begin{array}{l}\text { White and } \\
\text { brown chert }\end{array}$ & Quartz & $\begin{array}{l}\text { Quartz, opal-CT, } \\
\text { quartz-replaced } \\
\text { calcite debris }\end{array}$ & & Quartz & $\begin{array}{l}\text { Quartz, opal-CT, } \\
\text { quartz-replaced } \\
\text { calcite debris }\end{array}$ & $\begin{array}{l}\text { Coccoliths } \\
\text { replaced by } \\
\mathrm{SiO}_{2}\end{array}$ \\
\hline $463-33-2,85$ & Brown chert & Quartz & Quartz & & Quartz, opal-CT & $\begin{array}{l}\text { Quartz, opal-CT, } \\
\mathrm{SiO}_{2} \text {-replaced } \\
\text { carbonate debris }\end{array}$ & $\begin{array}{l}\text { Coccoliths } \\
\text { replaced by } \\
\mathrm{SiO}_{2}\end{array}$ \\
\hline $463-40, \mathrm{CC}$ & Gray chert & Quartz & $\begin{array}{l}\text { Coccoliths replaced } \\
\text { by } \mathrm{SiO}_{2} \text {, quartz, } \\
\text { opal-CT }\end{array}$ & & Quartz & Opal-CT & \\
\hline \multirow[t]{3}{*}{$463-45, \mathrm{CC}$} & 1. Gray chert & 1. Quartz ghosts & 1. Quartz & & Chalk: calcite & Calcite & \\
\hline & $\begin{array}{l}\text { 2. Siliceous } \\
\text { chalk }\end{array}$ & 2. Quartz & $\begin{array}{l}\text { 2. Microquartz } \pm \\
\text { opal-CT (most), } \\
\text { calcite } \pm \text { zeolites? }\end{array}$ & & & & \\
\hline & 3. Chalk & 3. Opal-A & $\begin{array}{l}\text { 3. Calcite, opal-CT, } \\
\text { quartz }\end{array}$ & & & & \\
\hline $463-49, \mathrm{CC}$ & Gray chert & Quartz ghosts & Quartz & & & & \\
\hline \multirow[t]{2}{*}{$463-54, C C$} & $\begin{array}{l}\text { Siliceous chalk, } \\
\text { chert burrows }\end{array}$ & 1. Chalk: quartz & $\begin{array}{l}\text { 1. Calcite } \pm \text { quartz } \\
\pm \text { opal-CT }\end{array}$ & & $\begin{array}{l}\text { 1. Chalk: calcite } \\
\text { 2. Chert: quartz }\end{array}$ & $\begin{array}{l}\text { 1. Calcite } \\
\text { 2. Quartz, opal-CT }\end{array}$ & \\
\hline & & $\begin{array}{l}\text { 2. Chert: fragments } \\
\text { of cell walls } \\
\text { opal-A; quartz } \\
\text { ghosts }\end{array}$ & $\begin{array}{l}\text { 2. Quartz and (or) } \\
\text { opal-CT }\end{array}$ & & & & \\
\hline \multirow[t]{3}{*}{$463-60-1,30$} & 1. Chert & 1. Quartz ghosts & 1. Microquartz & & & & \\
\hline & $\begin{array}{l}\text { 2. Siliceous } \\
\text { chalk }\end{array}$ & $\begin{array}{l}\text { 2. Quartz, opal-CT, } \\
\text { calcite ghosts }\end{array}$ & $\begin{array}{l}\text { 2. Quartz, opal-CT, } \\
\text { calcite, zeolite?; } \\
\text { mostly one large } \\
\text { calcite crystal in } \\
\text { each }\end{array}$ & & $\begin{array}{l}\text { Siliceous chalk: } \\
\text { recrystallized coarse } \\
\text { calcite }\end{array}$ & Calcite & \\
\hline & 3. Porcellanite & 3. Quartz ghosts & & & & & \\
\hline $463-60-1,82$ & $\begin{array}{l}\text { Extensively } \\
\text { burrowed } \\
\text { siliceous chalk }\end{array}$ & Calcite & Calcite & & & $\begin{array}{l}\text { Recrystallized } \\
\text { calcite }\end{array}$ & \\
\hline \multirow[t]{3}{*}{$463-69-1,74$} & $\begin{array}{l}\text { Chalk/chert } \\
\text { contact }\end{array}$ & 1. Chalk & $\begin{array}{l}\text { 1. Microquartz and } \\
\text { (or) calcite (rare), } \\
\text { quartz replaced }\end{array}$ & & $\begin{array}{l}\text { 1. Chalk: } \\
\text { recrystallized } \\
\text { calcite }\end{array}$ & 1. Quartz & \\
\hline & & & $\begin{array}{l}\text { opal-CT, } \\
\text { chalcedony (rare) }\end{array}$ & & $\begin{array}{l}\text { 2. Chert: quartz } \\
\text { ghosts (rare) }\end{array}$ & 2. Quartz & \\
\hline & & $\begin{array}{l}\text { 2. Chert: quartz } \\
\text { ghosts, calcite } \\
\text { (rare) }\end{array}$ & $\begin{array}{l}\text { 2. Microquartz, } \\
\text { chalcedony (rare), } \\
\text { pyrite }\end{array}$ & & & & \\
\hline
\end{tabular}


Table 4. (Continued).

\begin{tabular}{|c|c|c|c|c|c|c|c|}
\hline \multirow[b]{2}{*}{ Sample } & \multirow[b]{2}{*}{ Host Rock } & \multicolumn{3}{|c|}{ Radiolarians } & \multicolumn{3}{|c|}{ Foraminifers } \\
\hline & & Tests & Filling & Remarks & Tests & Filling & Remarks \\
\hline $463-81-2,3$ & $\begin{array}{l}\text { Highly } \\
\text { burrowed gray, } \\
\text { wavy laminated } \\
\text { chert-chalk }\end{array}$ & $\begin{array}{l}\text { 1. Chert: quartz } \\
\text { ghosts, opal-CT or } \\
\text { opal-A } \\
\text { 2. Chalk: quartz, } \\
\text { opal-CT, or opal-A }\end{array}$ & $\begin{array}{l}\text { 1. Microquartz } \\
\text { 2. Calcite, opal-CT?, } \\
\text { pyrite lined, empty }\end{array}$ & & $\begin{array}{l}\text { Chalk: recrystallized } \\
\text { calcite }\end{array}$ & Quartz & \\
\hline $463-81, C C$ & $\begin{array}{l}\text { Extensively } \\
\text { burrowed, } \\
\text { banded white } \\
\text { and gray chert } \\
\text { and siliceous } \\
\text { chalk }\end{array}$ & $\begin{array}{l}\text { 1. Chert: quartz, } \\
\text { opal-CT? } \\
\text { 2. Calcareous chert: } \\
\text { some quartz }\end{array}$ & $\begin{array}{l}\text { 1. Quartz, chalcedony } \\
\text { 2. Calcite and quartz, } \\
\text { calcite, micro- } \\
\text { quartz, } \\
\text { chalcedony, } \\
\text { cryptocrystalline } \\
\text { quartz or opal-CT, } \\
\text { empty }\end{array}$ & & Chert: quartz & Quartz & $\begin{array}{l}\text { Coccoliths } \\
\text { replaced by } \\
\mathrm{SiO}_{2}\end{array}$ \\
\hline $463-89-1,35$ & Calcareous chert & $\begin{array}{l}\text { 1. Chalk: quartz, } \\
\text { opal-CT, or opal-A } \\
\text { 2. Carbonate burrow: } \\
\text { quartz } \\
\text { 3. Chert: quartz } \\
\text { ghosts }\end{array}$ & $\begin{array}{l}\text { 1. Calcite (1 or } 2 \\
\text { large crystals), } \\
\text { pyrite, quartz } \\
\text { 2. Calcite, quartz } \\
\text { (rare) } \\
\text { 3. Calcite, quartz, } \\
\text { pyrite }\end{array}$ & & Chert: quartz & $\begin{array}{l}\text { Quartz and quartz- } \\
\text { replaced opal-CT } \\
\text { lepispheres }\end{array}$ & \\
\hline $464-11-1,22$ & $\begin{array}{l}\text { Laminated } \\
\text { porcellanite } \\
\text { with quartz } \\
\text { veins }\end{array}$ & $\begin{array}{l}\text { Porcellanite: quartz, } \\
\text { opal-CT }\end{array}$ & $\begin{array}{l}\text { Quartz and } \\
\text { chalcedony, quartz- } \\
\text { replaced opal-CT } \\
\text { lepispheres }\end{array}$ & & & & \\
\hline $464-11-1,41$ & $\begin{array}{l}\text { Orange jasper } \\
\text { with quartz } \\
\text { veins }\end{array}$ & Quartz ghosts & $\begin{array}{l}\text { Microquartz, } \\
\text { hematite }\end{array}$ & & & & \\
\hline $464-14-1,10$ & $\begin{array}{l}\text { Gray chert } \\
\text { porcellanite, } \\
\text { siliceous chalk }\end{array}$ & $\begin{array}{l}\text { 1. Chert: quartz } \\
\text { ghosts } \\
\text { 2. Chalk: quartz }\end{array}$ & $\begin{array}{l}\text { 1. Microquartz, } \\
\text { pyrite } \\
\text { 2. Microquartz, } \\
\text { calcite (rare), } \\
\text { pyrite (geopedal) }\end{array}$ & Spicule ghosts & & & \\
\hline $464-14-1,40$ & $\begin{array}{l}\text { Extensively } \\
\text { burrowed, } \\
\text { pyritized, gray } \\
\text { radiolarian chert }\end{array}$ & $\begin{array}{l}\text { Quartz ghosts, calcite } \\
\text { (rare), quartz- } \\
\text { replaced opal-CT }\end{array}$ & $\begin{array}{l}\text { Microquartz, pyrite, } \\
\text { clay, quartz-replaced } \\
\text { opal-CT }\end{array}$ & & & & \\
\hline $464-17, \mathrm{CC}$ & $\begin{array}{l}\text { Siliceous red } \\
\text { jasper, exten- } \\
\text { sively burrowed, } \\
\text { with white } \\
\text { siliceous chalk } \\
\text { rims }\end{array}$ & Microquartz & $\begin{array}{l}\text { Microquartz, } \\
\text { chalcedony }\end{array}$ & & Calcite ghosts & $\begin{array}{l}\text { Microquartz, } \\
\text { calcite }\end{array}$ & \\
\hline $464-27-1,23$ & Jasper & Quartz & $\begin{array}{l}\text { Quartz, opal-CT or } \\
\text { quartz-replaced } \\
\text { opal-CT, calcite (rare) }\end{array}$ & & Quartz & $\begin{array}{l}\text { Quartz, opal-CT or } \\
\text { quartz-replaced } \\
\text { opal-CT } \\
\text { lepispheres }\end{array}$ & \\
\hline $464-29-1,138$ & $\begin{array}{l}\text { Dark-brown } \\
\text { chert with light- } \\
\text { brown chert } \\
\text { burrows }\end{array}$ & $\begin{array}{l}\text { Quartz ghosts, calcite } \\
\text { (rare) }\end{array}$ & $\begin{array}{l}\text { Quartz, magnetite } \\
\text { and (or) hematite, } \\
\text { chalcedony (rare), } \\
\text { opal-CT? }\end{array}$ & $\begin{array}{l}\text { Radiolarians } \\
\text { slightly } \\
\text { flattened and } \\
\text { aligned with } \\
\text { other grains } \\
\text { parallel to } \\
\text { burrows }\end{array}$ & Quartz ghosts & $\begin{array}{l}\text { Quartz or quartz- } \\
\text { replaced opal-CT }\end{array}$ & \\
\hline $466-34-1,77$ & $\begin{array}{l}\text { Calcareous } \\
\text { opal-CT } \\
\text { porcellanite }\end{array}$ & $\begin{array}{l}\text { No cell walls, } \\
\text { carbonate-replaced, } \\
\text { chalcedony, } \\
\text { opal-CT; } \\
\text { opal-CT }\end{array}$ & $\begin{array}{l}\text { Microquartz } \\
\text { Microquartz } \\
\text { Microquartz } \\
\text { Microquartz } \\
\text { opal-CT }\end{array}$ & & $\begin{array}{l}\text { Recrystallized } \\
\text { carbonate }\end{array}$ & $\begin{array}{l}\text { Pyrite, opal-CT, } \\
\text { opal-CT and car- } \\
\text { bonate, carbonate, } \\
\text { quartz and (or) } \\
\text { opal-CT }\end{array}$ & \\
\hline
\end{tabular}

of grain size toward the center of the veins (for example 464-29-1, $138 \mathrm{~cm}$ ). Radiating growths of iron- or ironmanganese oxides line the walls of one vein, including the surface of a host-rock fragment floating in the vein quartz (Plate 12, Figs 3, 4; see also Keene, 1975). OpalCT lepispheres were replaced by quartz in one vein, and opal-CT may have been precursor to other vein quartz in Leg 62 samples. Many of these features have been described previously (Lancelot, 1973; Keene, 1976; Kelts, 1976).

We studied four rock types that are uncommon or texturally odd. These include (1) a chert breccia, (2) a transition zone between white porcellanite, containing opal-CT and quartz and a burrowed brown chert, (3) a chert from Paleogene calcareous ooze where silica may have replaced sulfate minerals, and (4) a chert that consists of silica-replaced calcite pseudospherules and streaks and circular masses of dense quartz chert.

A few chert breccias cemented by opal-CT, quartz, and chalcedony were recovered from Hole 464. Sample 464-11-1, $5 \mathrm{~cm}$ consists of angular to rounded fragments of clay and iron-rich chert clasts containing rare molds of radiolarians and microquartz veins. The clasts are cemented by colloform opal-CT and chalcedony (Plates 
12, Figs. 1, 2; 13, Figs. 3-6). In places, opal-CT lepispheres coat the clasts, and length-fast chalcedony fills the remaining pore space. In other places, iron oxides coat clasts or fill the interstices. The colloform opal-CT-chalcedony cement seems to be unique to Leg 62 breccias; we are not aware of such cements in other breccias recovered from DSDP holes. Clasts in the breccia do not fit back together on the scale of hand sample, and fragments evidently have been displaced many centimeters at least.

Keene (1975) suggested that similar breccias from DSDP Leg 32 resulted from differential compaction of porous, unlithified clay between silicified layers. Differential compaction is also a reasonable explanation for Site 464 breccias which occur in the upper part of a limestone-chert sequence near its contact with overlying compacted brown clay. The two sequences are separated by at least a $20-\mathrm{m} . \mathrm{y}$. hiatus. Extensively veined rocks, mostly jaspers, occur near the breccias.

An uncommon and odd feature occurs in Turonian Sample 463-31,CC, in a zone transitional between white porcellanite containing quartz and opal-CT and a burrowed brown chert. The transition zone consists of radial clusters of opal-CT with holes at the center of the clusters (Plate 13, Figs. 1, 2). The radial fibers merge with massive quartz in the chert and are apparently the sustenance for the growth of the chert. The radial clusters also intertwine with adjacent clusters, and can be distorted either as the result of compression or from growth within a confined space.

A photo of similar radial opal-CT clusters in a middle Eocene opal-CT chert from the central Pacific (DSDP Leg 7) was presented by Wise and Weaver (1974), but they offered no explanation for the formation of the clusters. The only other report we are aware of is by Imoto and Saito (1973), who show what appear to be identical, hollow, radial quartz aggregates from the Precambrian Gunflint Chert. They suggest that the aggregates were precipitated by the activity of some microorganisms. The Gunflint structures are different in that they are 30 to $40 \mu \mathrm{m}$ in diameter, compared to 8 to 11 $\mu \mathrm{m}$ for Leg 62 and 5 to $8 \mu \mathrm{m}$ for Leg 7 samples.

One possible sequence for the formation of the radial structures is shown in Figure 5: (1) calcareous nannofossils are overgrown with and partly replaced by opal-CT; (2) some dissolution of the nannofossils occurs adjacent to central cavity; (3) the nannofossils are completely replaced by silica, and crystal growth extends the overgrowths; and (4) maturation and possibly remobilization of silica produces massive chert adjacent to the radial clusters. It is not clear why the central cavities did not fill by precipitation of opal-CT. We speculate that formation of this uncommon texture may depend on the "proper" proportions of a silica source (radiolarians) to carbonate host (chalk), and on a high porosity and probably permeability of the deposit during silicification. A form similar to the coccolith (or a spicule) may be necessary for formation of this texture, and this might say something about the nature of the Gunflint micro-organisms.
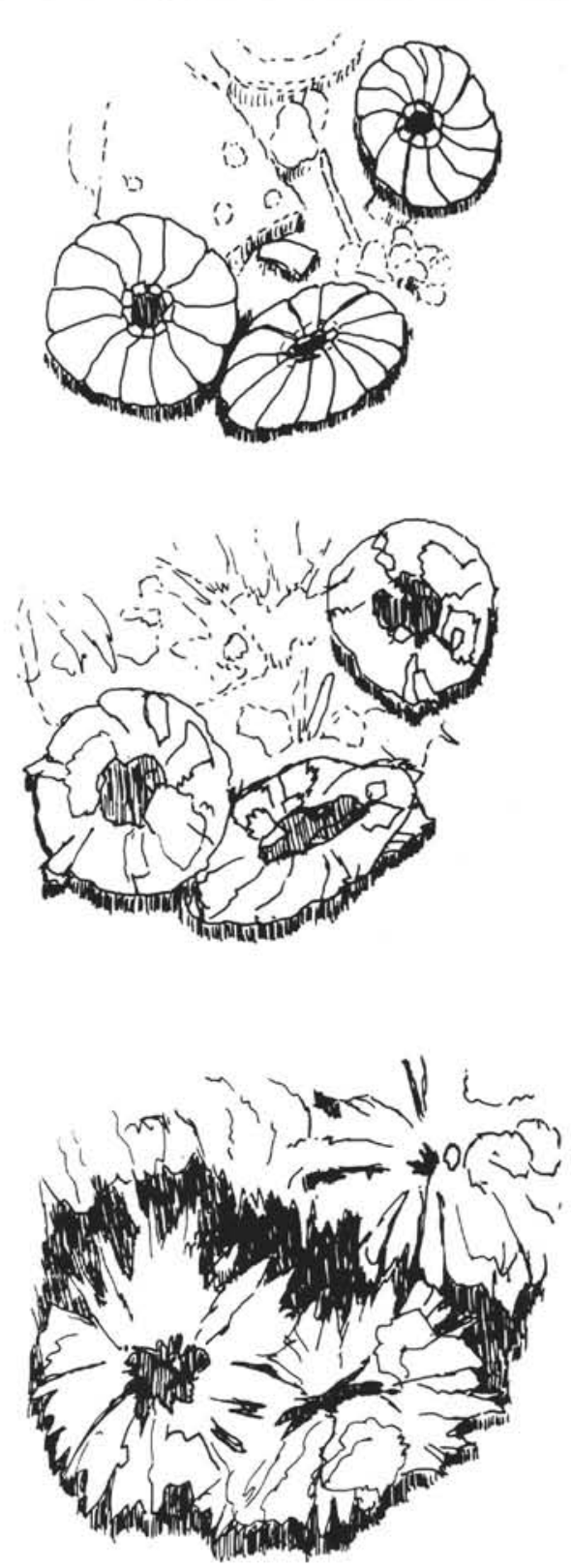

\section{$10 \mu \mathrm{m}$}

Figure 5. Possible diagenetic sequence for the formation of radial opal-CT structures with hollow centers. Nannofossils are overgrown with and partly replaced by opal-CT; dissolution of calcite occurs adjacent to the central cavity; finally the nannofossils are completely replaced by silica, and crystal growth extends the overgrowths. See Plate 13 for photomicrographs of these structures.

Hole 465 cherts which formed in Paleocene nannofossil ooze shows two odd textures. These features have not been reported in other deep-sea cherts, and thereby warrant detailed descriptions. The cherts occur both along and 30 meters below the unconformity that 
represents a 55-m.y. hiatus between Pleistocene and Paleocene calcareous ooze. In hand specimen, Sample $465-2, C C$ is a somewhat cloudy and translucent, gray chert, surrounded or rimmed by white quartz porcellanite (Plate 1, Fig. 6). In thin section, the chert includes areas of exceedingly clean microquartz, with some more coarsely crystalline radiolarian molds, adjacent to areas of burrowed chert that have scattered, minute calcite grains and abundant, unidentifiable, isotropic patches and grains that resemble halite and collophane.

SEM shows that the porcellanite was a chalk which has been completely silicified, and the chert (EDAX shows only $\mathrm{Si}$ ) is very fine-grained and studded with 10to $15-\mu \mathrm{m}$ crystals of various forms (Plate 15, Figs. $1,2)$. Some crystals are obviously hexagonal. Many crystals were corroded and etched before replacement. EDAX results show $\mathrm{Si}$ and a trace of $\mathrm{Na}$ in the crystals. Some crystals have elongate inclusions paralleling their long axis (Plate 15, Fig. 1). The inclusions are richer in $\mathrm{Na}$ than are adjacent areas of the crystals. The crystals do not occur in voids, but are quartz-replaced crystals in the host cherts. We suggest that these crystals were sulfate minerals which have been replaced by quartz and are probably pseudomorphs after gypsum or anhydrite. Rare cubic forms seen with the SEM may be replaced halite.

Our interpretation is strengthened by the presence of a filled void in this same sample $(465-2, C C)$ that contains calcite, apatite, and either gypsum or anhydrite ( $\mathrm{Ca}$ and $\mathrm{S}$ identified with EDAX). The gypsum or anhydrite identification in this sample is strengthened by the appearance of bladed gypsum sheaths (Plate 15, Fig. 5) in Sample 465-5-2, $118 \mathrm{~cm}$, approximately 20 meters lower in the section. The Na-rich inclusions are probably fluid (salt water) inclusions in the original mineral that somehow resisted quartz replacement.

The geologic conditions that produced the sulfate minerals which have been replaced by quartz are not fully understood, but we can speculate on both the original formation of the sulfates and their replacement by quartz. Two possibilities for the formation of this chert are: (1) the sulfate minerals formed in shallow water near subaerially exposed areas along southern Hess Rise and were either replaced by silica in situ and transported to deeper water, or transported to deeper water and subsequently replaced by silica; or (2) the sulfate minerals formed entirely within a deeper-water environment and were subsequently replaced by quartz.

We favor the second hypothesis, because the chert apparently formed in situ. However, we cannot completely rule out the first mechanism, because the present shallow depths along southern Hess Rise (Mellish Bank is less than $120 \mathrm{~m}$ deep, and a large part of the rise is less than 2,000 $\mathrm{m}$ deep) indicate that at least parts of the rise were probably above and (or) close to sea level during the Paleocene. Parts of southern Hess Rise may have been above sea level during the latest Cretaceous, because rounded volcanic clasts occur in sediment of that age at Site 466, and displaced shallow water fauna and flora were found in uppermost Cretaceous strata at Site 465 (Vallier et al., this volume).
However, Site 465 definitely was not emergent during the Paleocene. Quartz pseudomorphs after sulfate minerals have not been reported from other DSDP sites, but silica apparently replaced evaporites in parts of some bedded chert sequences that now crop out on land (McBride and Folk, 1977). Petrographic types of quartz commonly associated with replacement of evaporites, such as quartzine and lutecite (Folk and Pittman, 1971; Milliken, 1979, were not observed in these Site 465 samples.

A final odd texture occurs in a quartz porcellanite from Paleocene nannofossil ooze recovered 20 meters below the chert at Site 465 that contains quartz pseudomorphs after sulfate minerals. This sample, $465-5-2,118 \mathrm{~cm}$, consists of silica which has replaced calcite pseudospherules (EDAX shows $\mathrm{Si}$ with minor $\mathrm{Ca}$ ), and also of streaks and circular masses of dense quartz chert (EDAX shows Si with a trace of Na; Plate 14). Chert and silicified chalk are similarly distributed in other samples, but only in this sample is the silicified carbonate composed of uniform, evenly distributed patches of $<1-\mu \mathrm{m}$ pseudospherical grains that display an apparent preferred orientation (Plate 14).

This quartz porcellanite also contains rare molds of spicules, radiolarians, and foraminifers; rare bladed gypsum sheaths and ferruginous dolomite rhombs; and rare voids filled with calcite and corroded, overgrown calcareous nannofossils. One small area is studded with quartz pseudomorphs after sulfate crystals, as described above.

The origin of this odd chert texture is unclear. Perhaps the oriented pseudosphere structures result from recrystallization of quartz which has replaced calcareous algae. As with Sample 465-2,CC, evaporite minerals may be associated with development of this older chert.

\section{GEOCHEMISTRY}

The 24 rocks analyzed for major and minor elements included 10 cherts (pure quartz cherts that are nearly free of accessory minerals), 3 jaspers (yellow-brown and red-brown vitreous chert), 3 quartz porcellanites, 3 tuffaceous cherts, 2 calcareous cherts, 1 calcareous porcellanite, and 2 chalks (Tables 5 and 6). Many elements in cherts are closely related to major mineral components (Fig. 6). The carbonate component of the cherts is distinguished not only by high $\mathrm{CaO}$ and $\mathrm{MgO}$ contents, but also by high values of $\mathrm{Mn}, \mathrm{Ba}, \mathrm{Sr}$, and (for unknown reasons) $\mathrm{Zr}$ (Fig. 6; Table 5); $\mathrm{Mn}$ is also abundant in porcellanites. These elements are displaced when the carbonate is replaced by silica. Tuffaceous chert is characterized by high $\mathrm{K}$ and $\mathrm{Al}$, and also commonly has high $\mathrm{Zn}, \mathrm{Mo}$, and $\mathrm{Cr}$ contents. Pure cherts are characterized by high $\mathrm{SiO}_{2}$ and $\mathrm{B}$, and only small amounts of other elements (Fig. 6). Boron decreases markedly as the carbonate, volcanic, and terrigenous contents increase in the chert samples; apparently B is accommodated within the quartz structure. Boron may be derived from sea water or it may be related to the presence of organic matter at the time of quartz precipitation. Boron was retained through the quartz porcellanite to chert transfor- 
Table 5. Chemistry of cherts, porcellanites, and siliceous carbonates of DSDP Leg 62 .

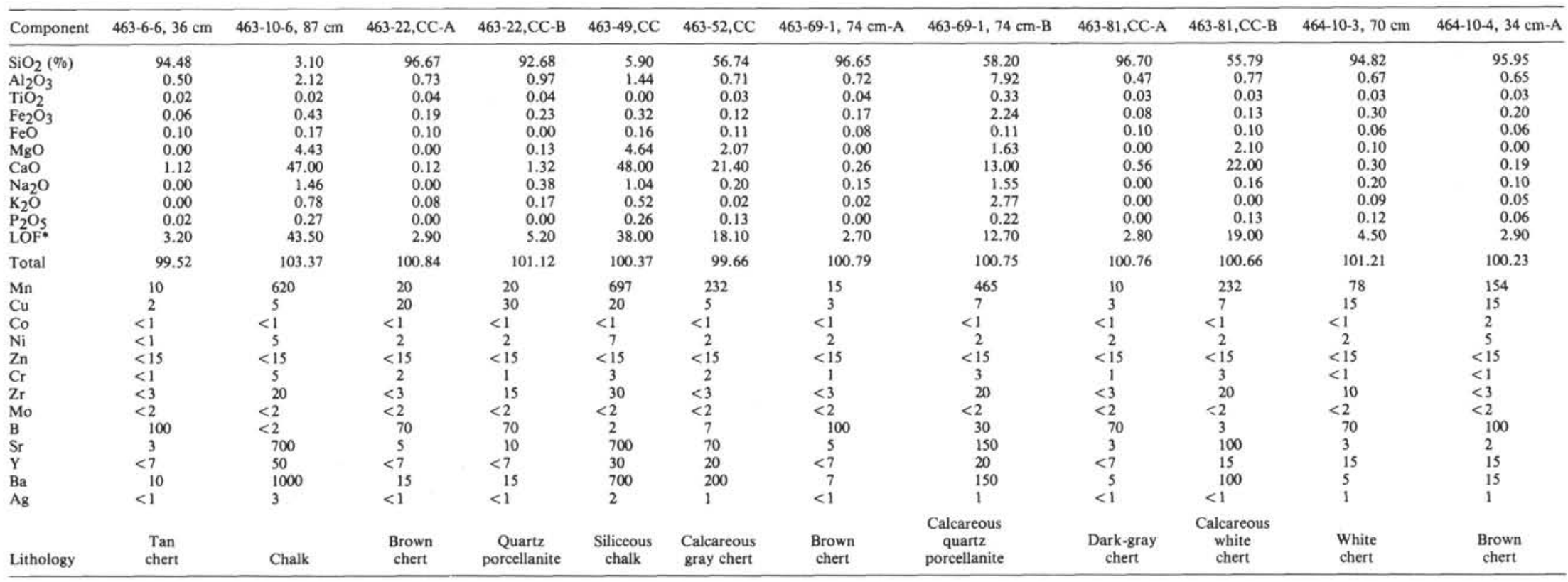


Table 5. (Continued).

\begin{tabular}{|c|c|c|c|c|c|c|c|c|c|c|c|c|}
\hline Component & $464-10-4,34 \mathrm{~cm}-\mathrm{B}$ & $464-11-1,41 \mathrm{~cm}$ & $464-14-1,40 \mathrm{~cm}$ & $464-17, \mathrm{CC}$ & 465-2,CC-A & $465-2$, CC-B & $465 \mathrm{~A}-40-1,26 \mathrm{~cm}-\mathrm{A}$ & $465 \mathrm{~A}-40-1,26 \mathrm{~cm}-\mathrm{B}$ & $466-8-1,10 \mathrm{~cm}-\mathrm{B}$ & $466-9-1,64 \mathrm{~cm}$ & $466-15-5,45 \mathrm{~cm}$ & $466-34-1,8 \mathrm{~cm}$ \\
\hline $\mathrm{SiO}_{2}(\%)$ & 94.55 & 93.94 & 95.77 & 94.87 & 96.93 & 96.25 & 79.33 & 80.98 & 82.14 & 97.34 & 97.00 & 96.40 \\
\hline $\mathrm{Al}_{2} \mathrm{O}_{3}$ & 0.44 & 0.69 & 0.97 & 0.85 & 0.86 & 0.36 & 7.57 & 7.60 & 7.60 & 0.76 & 0.68 & 0.60 \\
\hline $\mathrm{TiO}_{2}$ & 0.16 & 0.03 & 0.05 & 0.05 & 0.02 & 0.02 & 0.35 & 0.35 & 0.35 & 0.03 & 0.03 & 0.03 \\
\hline $\mathrm{Fe}_{2} \mathrm{O}_{3}$ & 0.35 & 2.78 & 0.30 & 1.08 & 0.09 & 0.05 & 2.17 & 2.22 & 2.18 & 0.09 & 0.13 & 0.14 \\
\hline $\mathrm{FeO}$ & 0.00 & 0.05 & 0.06 & 0.20 & 0.06 & 0.06 & 0.10 & 0.11 & 0.10 & 0.06 & 0.06 & 0.05 \\
\hline $\mathrm{MgO}$ & 0.00 & 0.08 & 0.00 & 0.03 & 0.00 & 0.00 & 0.50 & 0.52 & 0.56 & 0.00 & 0.00 & 0.00 \\
\hline $\mathrm{CaO}$ & 0.43 & 0.10 & 0.13 & 0.68 & 0.12 & 0.42 & 1.40 & 1.20 & 1.11 & 0.11 & 0.10 & 0.10 \\
\hline $\mathrm{Na}_{2} \mathrm{O}$ & 0.51 & 0.13 & 0.00 & 0.00 & 0.13 & 0.12 & 1.19 & 1.21 & 1.31 & 0.13 & 0.00 & 0.00 \\
\hline $\mathrm{K}_{2} \mathrm{O}$ & 0.11 & 0.19 & 0.11 & 0.05 & 0.01 & 0.02 & 2.64 & 2.68 & 2.65 & 0.00 & 0.00 & 0.02 \\
\hline $\mathrm{P}_{2} \mathrm{O}_{5}$ & 0.19 & 0.00 & 0.02 & 0.02 & 0.00 & 0.02 & 0.17 & 0.18 & 0.13 & 0.00 & 0.00 & 0.00 \\
\hline LOF* & 2.90 & 3.20 & 2.70 & 3.10 & 3.00 & 3.20 & 3.50 & 2.70 & 2.50 & 1.90 & 3.00 & 2.50 \\
\hline Total & 99.69 & 101.21 & 100.12 & 100.94 & 101.24 & 100.52 & 98.95 & 99.78 & 100.69 & 100.43 & 101.01 & 99.92 \\
\hline $\mathrm{Mn}$ & 387 & 46 & 20 & 30 & 78 & 3 & 154 & 154 & 154 & 78 & 50 & 620 \\
\hline $\mathrm{Cu}$ & 20 & 20 & 50 & 10 & 3 & 10 & 10 & 10 & 2 & 1 & 3 & 3 \\
\hline Co & 3 & $<1$ & 1 & $<1$ & $<1$ & $<1$ & $<1$ & $<1$ & $<1$ & $<1$ & $<1$ & $<1$ \\
\hline $\mathrm{Ni}$ & 15 & 3 & 10 & 3 & 1 & 2 & 20 & 20 & 2 & $<1$ & $<1$ & 2 \\
\hline $\mathrm{Zn}$ & $<15$ & $<15$ & $<15$ & $<15$ & $<15$ & $<15$ & 70 & 70 & $<15$ & $<15$ & $<15$ & $<15$ \\
\hline $\mathrm{Cr}$ & $<1$ & 2 & 2 & 2 & $<1$ & $<1$ & 5 & 7 & $<1$ & $<1$ & $<1$ & 1 \\
\hline $\mathrm{Zr}$ & 15 & is & $<3$ & $<3$ & $<3$ & $<3$ & $<3$ & $<3$ & $<3$ & $<3$ & $<3$ & $<3$ \\
\hline Mo & $<2$ & $<2$ & $<2$ & $<2$ & $<2$ & $<2$ & 10 & 10 & 2 & 2 & 2 & $<2$ \\
\hline B & 70 & 70 & 70 & 50 & 100 & 100 & 30 & 30 & 70 & 50 & 70 & 30 \\
\hline $\mathrm{Sr}$ & 5 & 2 & 1 & 10 & $<1$ & 3 & 7 & 5 & $<1$ & $<1$ & $<1$ & $<1$ \\
\hline $\mathrm{Y}$ & 30 & $<7$ & $<7$ & 10 & $<7$ & $<7$ & 7 & 15 & 15 & 15 & 15 & is \\
\hline $\mathrm{Ba}$ & 5 & 10 & 7 & 15 & 10 & 10 & 10 & 15 & 10 & 15 & 15 & 10 \\
\hline $\mathrm{Ag}$ & 2 & $<1$ & $<1$ & $<1$ & $<1$ & $<1$ & $<1$ & $<1$ & $<1$ & $<1$ & $<1$ & $<1$ \\
\hline Lithology & $\begin{array}{c}\text { Quartz } \\
\text { porcellanite }\end{array}$ & $\begin{array}{l}\text { Orange } \\
\text { jasper }\end{array}$ & $\begin{array}{l}\text { Black } \\
\text { chert }\end{array}$ & $\begin{array}{l}\text { Red-brown } \\
\text { jasper }\end{array}$ & $\begin{array}{c}\text { Gray } \\
\text { transparent } \\
\text { chert }\end{array}$ & $\begin{array}{c}\text { Quartz } \\
\text { porcellanite }\end{array}$ & $\begin{array}{l}\text { Tuffaceous } \\
\text { black } \\
\text { chert }\end{array}$ & $\begin{array}{l}\text { Tuffaceous } \\
\text { gray-green } \\
\text { chert }\end{array}$ & $\begin{array}{l}\text { Tuffaceous } \\
\text { brown } \\
\text { chert }\end{array}$ & $\begin{array}{l}\text { Gray } \\
\text { chert }\end{array}$ & $\begin{array}{l}\text { Brown } \\
\text { jasper }\end{array}$ & $\begin{array}{l}\text { Blue-gray } \\
\text { chert }\end{array}$ \\
\hline
\end{tabular}

Note: Other elements were scanned, but are below the limits of detection (in parentheses in ppm): $\mathrm{As}(<100), \mathrm{Au}(<7), \mathrm{Be}(<0.7), \mathrm{Bi}(<7), \mathrm{Cd}(<7), \mathrm{La}(<7), \mathrm{Nb}(<7), \mathrm{Pb}(<7), \mathrm{Pd}(<1), \mathrm{Pt}(<5), \mathrm{Sb}(<15), \mathrm{Sc}(<0.7), \mathrm{Sn}(<2), \mathrm{Te}(<300)$,

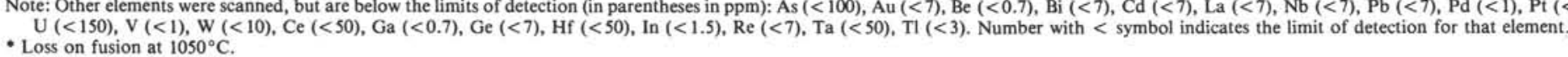


Table 6. Average compositions and standard deviations for major rock types analyzed in Table 5.

\begin{tabular}{|c|c|c|c|c|c|c|c|}
\hline Component & Chert & Jasper & $\begin{array}{c}\text { Quartz } \\
\text { Porcellanite }\end{array}$ & $\begin{array}{c}\text { Tuffaceous } \\
\text { Chert }\end{array}$ & $\begin{array}{l}\text { Calcareous } \\
\text { Chert }\end{array}$ & $\begin{array}{l}\text { Calcareous } \\
\text { Porcellanite }\end{array}$ & Chalk \\
\hline $\mathrm{SiO}_{2}(\%)$ & $96.17(0.92)$ & $95.27(1.57)$ & $94.49(1.79)$ & $80.82(1.41)$ & $56.27(0.67)$ & 58.20 & $4.50(1.98)$ \\
\hline $\mathrm{Al}_{2} \mathrm{O}_{3}$ & $0.69(0.15)$ & $0.74(0.10)$ & $0.59(0.33)$ & $7.59(0.02)$ & $0.74(0.04)$ & 7.92 & $1.78(0.48)$ \\
\hline $\mathrm{TiO}_{2}$ & $0.03(0.01)$ & $0.04(0.01)$ & $0.07(0.08)$ & $0.35(0.00)$ & $0.03(0.00)$ & 0.33 & $0.01(0.01)$ \\
\hline $\mathrm{Fe}_{2} \mathrm{O}_{3}$ & $0.16(0.09)$ & $1.33(1.34)$ & $0.21(0.15)$ & $2.19(0.03)$ & $0.13(0.01)$ & 2.24 & $0.38(0.08)$ \\
\hline $\mathrm{FeO}$ & $0.07(0.02)$ & $0.10(0.08)$ & $0.02(0.03)$ & $0.10(0.01)$ & $0.11(0.01)$ & 0.11 & $0.17(0.01)$ \\
\hline $\mathrm{MgO}$ & $0.01(0.03)$ & $0.04(0.04)$ & $0.04(0.08)$ & $0.53(0.03)$ & $2.09(0.02)$ & 1.63 & $4.54(0.15)$ \\
\hline $\mathrm{CaO}$ & $0.30(0.32)$ & $0.29(0.33)$ & $0.72(0.52)$ & $1.24(0.15)$ & $21.70(0.42)$ & 13.00 & $47.50(0.71)$ \\
\hline $\mathrm{Na}_{2} \mathrm{O}$ & $0.07(0.08)$ & $0.04(0.08)$ & $0.34(0.20)$ & $1.24(0.06)$ & $0.18(0.03)$ & 1.55 & $1.25(0.30)$ \\
\hline $\mathrm{K}_{2} \mathrm{O}$ & $0.04(0.04)$ & $0.08(0.10)$ & $0.10(0.08)$ & $2.66(0.02)$ & $0.01(0.01)$ & 2.77 & $0.65(0.18)$ \\
\hline $\mathrm{P}_{2} \mathrm{O}_{5}$ & $0.02(0.04)$ & $0.01(0.01)$ & $0.07(0.10)$ & $0.16(0.03)$ & $0.13(0.00)$ & 0.22 & $0.27(0.01)$ \\
\hline LOF* & $2.91(0.66)$ & $3.10(0.10)$ & $3.77(1.25)$ & $2.90(0.53)$ & $18.55(0.64)$ & 12.70 & $40.75(3.89)$ \\
\hline $\mathrm{Mn}$ (ppm) & 108 (186) & 42 (11) & $137(217)$ & $154(0.00)$ & $232(0.00)$ & 465 & $659(54)$ \\
\hline $\mathrm{Cu}$ & $12(15)$ & $11(9)$ & 20 (10) & 7 (5) & $6(1)$ & 7 & 13 (11) \\
\hline $\mathrm{Ni}$ & $3(3)$ & $2(2)$ & $6(8)$ & $14(10)$ & $2(0)$ & 2 & $6(1)$ \\
\hline $\mathrm{Cr}$ & 1 (1) & 1 (1) & - & $4(4)$ & 3 (1) & 3 & 4 (1) \\
\hline $\mathrm{Zr}$ & - & - & - & $<3$ & - & 20 & $25(7)$ \\
\hline B & $76(24)$ & $63(12)$ & 80 (17) & 43 (23) & $5(3)$ & 30 & - \\
\hline $\mathrm{Sr}$ & 2 (2) & $4(5)$ & $6(4)$ & 4 (4) & 85 (21) & 150 & $700(0)$ \\
\hline $\mathrm{Y}$ & - & - & - & $12(5)$ & 18 (4) & 20 & 40 (14) \\
\hline $\mathrm{Ba}$ & $10(4)$ & $13(3)$ & $10(5)$ & $12(3)$ & 150 (71) & 150 & 850 (212) \\
\hline $\begin{array}{l}\text { No, of } \\
\text { Samples }\end{array}$ & 10 & 3 & 3 & 3 & 2 & 1 & 2 \\
\hline
\end{tabular}

- Loss on fusion at $1050^{\circ} \mathrm{C}$.

mation. We speculate that high B contents in cherts and porcellanites have paleoenvironmental significance. High B may be a good indicator for the formation of chert in an open marine environment, isolated from volcanic and inorganic terrigenous materials.

In general, quartz porcellanites are richer in trace elements than are cherts, suggesting that most trace elements are rejected during the primarily textural transformation from quartz porcellanite to chert (Table 6). Unfortunately, we do not have chemical data on opalCT-rich porcellanites, where the chemical differences with cherts should be even more profound. Quartz porcellanites consistently contain more $\mathrm{Ca}, \mathrm{P}, \mathrm{Sr}$, and $\mathrm{Fe}^{+3}$ than do adjacent cherts, but less $\mathrm{Al}$ and $\mathrm{Fe}^{+2}$. Compared to cherts, porcellanites on the average contain more $\mathrm{Mn}, \mathrm{Cu}$, and $\mathrm{Ba}$; less $\mathrm{Fe}$; and equal $\mathrm{Ni}$. However, $\mathrm{Mn}$ is highly variable in all studied rock types.

Apparently, the Site 464 siliceous rocks are richer in trace elements than those from other sites drilled during Leg 62. Possibly the clay-rich section at Site 464 provided more trace elements or allowed more trace elements to be incorporated in the cherts than did calcareous sediments at other sites. For example, Co was detected only in cherts from Site 464 .

There are no obvious chemical trends with subbottom depths of Leg 62 siliceous rocks. This is true at each site, and when all sites are considered together. The only exception is at Site 463, where Y decreases with depth, considering only those samples with detectable amounts. Although color and chemistry are not consistently related, orange and red jaspers from Hole 464 and black cherts from Hole $465 \mathrm{~A}$ have high $\mathrm{Fe}_{2} \mathrm{O}_{3} / \mathrm{FeO}$ ratios (Table 5).

Leg 62 cherts are chemically very pure, averaging over $95 \% \mathrm{SiO}_{2}$ for both cherts and jaspers-in contrast to many impure Atlantic cherts containing up to $40 \%$ clay (Berger and von Rad, 1972). Chemical data support the genesis of cherts by silica replacement of carbonates and perhaps other minerals. During this re- placement, most elements were rejected from the parent rocks, and boron was incorporated into the precipitated silica. The high purity of most cherts indicates that extraneous biogenic, authigenic, terrigenous, and volcanic minerals are either replaced by silica or mechanically forced from the rock by silicification.

\section{DISCUSSION}

It is well established that the source of silica for Pacific cherts and porcellanites is siliceous microfossils that were composed of opal-A (Heath and Moberly, 1971; Keene, 1975; Hein et al., 1978). The general scheme of silicification also has been well delineated by the many authors listed in the introduction of this report.

Heath and Moberly (1971) and Keene (1976) succinctly summarized the basic steps for the formation of chert within a carbonate sequence: bladed opal-CT is precipitated in open spaces in the chalk, especially in microfossil chambers; opal-CT grows out from the places of initial precipitation to form a cement, and the host nannofossil chalk dissolves or is replaced by silica; carbonate microfossils rarely resist destruction, and those that do are pseudomorphically replaced by silica; porosity and permeability are reduced, and an opal-CT silicification front moves outward into the host chalk from a quartz-chert nucleus; foraminifers are replaced by chalcedony, and any remaining space in the tests is filled with chalcedony; growth of the nodule continues until biogenic silica in the surrounding chalk is eliminated.

From our work, these basic steps are added to and somewhat modified: first, tests of foraminifers and radiolarians and burrows are filled mainly with opal$\mathrm{CT}$, which is converted in the tests to chalcedonic quartz and microquartz in a relatively short time; second, the nannofossil host carbonate is partly cemented and replaced by opal-CT; silicified nannofossils are commonly preserved after the opal-CT inverts to quartz, ap- 

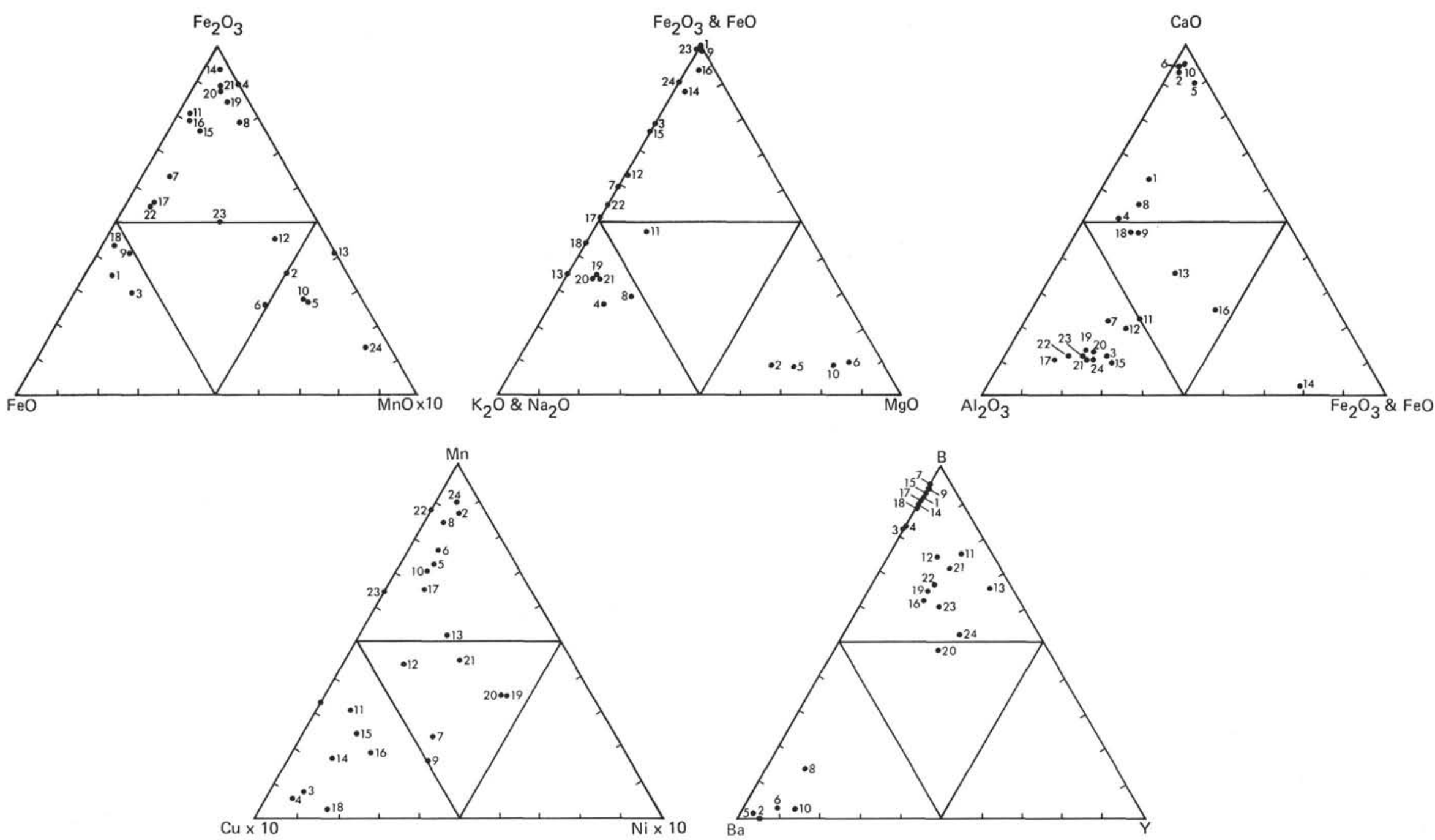

Figure 6. Ternary plots of elements and oxides that best define the various siliceous rocks studied. (Numbers refer to the 24 samples listed in Table 5 , starting with number 1 at the left) $1,3,7,9$ $11,12,15,17,22$, and 24 are chert; 14,16 , and 23 are jasper; 4,13 , and 18 are quartz porcellanite; 19,20 , and 21 are tuffaceous chert; 6 and 10 are calcareous chert; 8 is calcareous porcellanite; 2 and 5 are chalk. 
parently by solid-solid reactions; burrows are commonly the loci of initial silicification, and silicification spreads from these centers; at this stage, the rock (a porcellanite) is still very porous; third, the opal-CT converts to quartz, probably by solution-precipitation, producing porous quartz porcellanite; at any time during the first three stages, foraminifer tests may have been replaced by quartz, and possibly by opal-CT; fourth, vitreous, dense chert is formed by recrystallization and crystal growth of the quartz; test wall structure is lost on the remaining robust radiolarians, and they become ghosts in the microquartz chert; most foraminifers and all nannofossils are completely obliterated; some foraminifers survive the early parts of this stage, but only rarely do they survive even as ghosts as the stage progresses. Once a volume of dense chert is formed, silicification continues at its boundaries until all opal-A in the outlying carbonate is gone; the chert is in sharp contact with the surrounding quartz porcellanite (much less commonly opal-CT porcellanite), which in turn has a diffuse contact with surrounding chalk; newly formed dense chert commonly contains many microfossil impressions, which readily disappear after some aging of the chert, possibly by recrystallization; recrystallization is inferred from the wide variety of grain sizes occurring in Leg 62 cherts, from grains that are imperceptible with SEM to grains about $8 \mu \mathrm{m}$ in diameter; in general, the coarser the grain size, the fewer are the remnants remaining from the original deposits. Iijima et al. (1978) also noted this grain-size relationship in Triassic bedded cherts from central Japan.

Cherts first become abundant in Eocene deposits, indicating that widespread silicification did not begin until about 40 m.y. after deposition of the sediment; this is also true at other Pacific DSDP sites (Heath and Moberly, 1971; Keene, 1976). We suggest that once silicification was initiated it progressed relatively rapidly, possibly taking only a few millions of years to complete the steps just described. However, when biogenic silica in adjacent chalk is depleted, tens of millions of years apparently are required to convert the remaining quartz and opal-CT porcellanite rims to chert.

Chemical micro-environments are very important for determining the type of silica polymorph or other minerals that form within burrows, microfossil tests, and other parts of the rock. It is common to find three or four different minerals in different chambers of a single foraminifer, or two or three minerals within a single radiolarian or foraminifer chamber. Microenvironments not only determine what mineral initially precipitates, but also control the replacement, dissolution, and reprecipitation of minerals. The variety and variability of diagenetic minerals, especially in porcellanites, reflect significant differences in the chemical micro-environments. Chemical characteristics that must vary over minute distances include $p \mathrm{H}$, alkalinity, and the concentrations of $\mathrm{Si}, \mathrm{Ca}, \mathrm{Mg}, \mathrm{Fe}$, and other elements in pore waters within the micro-environment. Ultimately, however, everything is converted to or replaced by quartz.
We agree with Heath and Moberly (1971) and Keene (1975) that chert formation does not mechanically displace the host, but replaces the parent rock, as indicated by the preservation of structures, such as burrows, inherited from the host rock. During SEM study, we were impressed by the wide variety of non-hexagonal crystals that displayed only Si (quartz or opal-CT) on the EDAX spectra. As far as we could determine, quartz formed pseudomorphs after calcite, opal-A, opal-CT, pyrite, feldspar, gypsum, and other minerals. Upon recrystallization, evidence for these pre-existing minerals apparently was destroyed. Once the necessary initial conditions for silicification were obtained-that is, temperature (Hein et al., 1978), aging of silica, and chemical environment (Kastner et al., 1977)-silicification progressed rapidly. Rapid silicification ejected some foreign ions and other debris from the chalk, but most of the carbonate host was removed by volume-for-volume replacement of the host rock. In the deep-sea environment, 30 to $50 \mathrm{~m}$.y. may be required to set up the necessary initial conditions for silicification (Heath and Moberly, 1971).

Burrowing may control the initial place of silicification in many cherts. As mentioned, $78 \%$ of the Leg 62 cherts contain obvious burrows. However, it is often difficult to determine whether burrows were simply preserved during silicification or whether burrows actually played an integral role in the process of silicification. Two observations indicate that burrows were integral in the process of silicification. The youngest quartz chert at Site 463 is a cast of a burrow, and silica in burrows is always one step more advanced in silica diagenesis than is silica in the host porcellanite or chert. Thus, burrows commonly control not only the locus of silicification, but also the local mineralogy of silicathat is, opal-CT versus quartz. Radiolarians and foraminifers also act as points of initial silicification. In chalks, radiolarian- or foraminifer-rich areas and burrows provide the permeable and porous sediment texture necessary for silicification. In siliceous sections both radiolarian-rich areas and burrows provide the proper texture, and in clay sections burrows alone are important for silicification.

Very little in the literature concerns burrowing and silicification of deep-sea deposits. Several authors mentioned that burrows occur in deep-sea cherts (Heath, 1973; Garrison et al., 1975; Keene, 1975), and Beall et al. (1973) suggested that silica fronts tend to follow burrow zones, creating patchy silicification in extensively burrowed chalks. We have noted similar patchy silicification, but it occurs only in impure chalks, which implies that clays may have partly inhibited silicification. Kelts (1976) briefly described burrows in cherts from the central Pacific (DSDP Leg 33); he found that burrows can act as conduits for silicification and can also inhibit silicification, which results in relict chalk patches in the chert. We agree with his observation. In Leg 62 cherts, however, burrows most commonly were loci for precipitation and transport of silica. Burrows preserved as chalk-actually pink, brown, and orange iron-oxide 
concentrations with earthy textures-occur only in the jaspers in the clay-rich section at Site 464 (volume frontispiece, G).

Rare burrows have been noted in bedded chert sequences on land (McBride and Folk, 1977; Folk and McBride, 1978), but have not been reported in the abundance noted for Leg 62 cherts. Apparently, either the burrows were destroyed during late-stage recrystallization, or bedded chert sequences on land formed differently from those studied here.

Silicification of nannofossil limestone in the Franciscan Formation of California produced chert lenses and beds, a situation analogous to Leg 62 silicification; however, no burrows are evident in the chert from the Franciscan Calera Limestone (Wachs and Hein, 1974). Extensive silicified burrows occur in the chalks of England, and Kennedy (1975) and Kennedy and Garrison (1975) suggested that these cherts replaced uncemented infilling of burrows within hardgrounds. Kennedy (1975) stated that most flints in European chalks are silicified burrows. We suggest that burrowing may play a much greater role in the silicification of deep-sea carbonates than heretofore realized.

\section{ACKNOWLEDGMENTS}

We appreciate technical and analytical help from Eva Vanek, Sara Monteith, Robert Oscarson, and Kam Leong, of the U.S. Geological Survey. R. E. Garrison, University of California, Santa Cruz, and Caroline Isaacs, U.S. Geological Survey, provided critical reviews.

\section{REFERENCES}

Beall, A. D., Laury, R., Dickinson, K., and Pusey, W. C., 1973. Sedimentology. In Worzel, J. L., Bryant, W., et al., Init. Repts. DSDP, 10: Washington (U.S. Govt. Printing Office), 699-729.

Berger, W. H., and von Rad, U., 1972. Cretaceous and Cenozoic sediments from the Atlantic Ocean. In Hayes, D. E., Pimm, A. C., et al., Init. Repts. DSDP, 14: Washington (U.S. Govt. Printing Office), 787-954.

Calvert, S. E., 1971. Composition and origin of North Atlantic deep sea cherts. Contr. Mineral. Petrol., 33:273-288.

Cook, H. E., Johnson, P. D., Matti, J. C., et al., 1975. Methods of sample preparation and X-ray diffraction data analysis, X-ray mineralogy laboratory, Deep Sea Drilling Project, University of California, Riverside. In Hayes, D. E., and Frakes, L. A., et al., Init. Repts. DSDP, 28: Washington (U.S. Govt. Printing Office), 999-1007.

Ekdale, A. A., 1977. Abyssal trace fossils in worldwide Deep Sea Drilling Project cores. In Crimes, T. P., and Harper, J. C. (Eds.), Trace Fossils 2: Liverpool (Seel House Press), pp. 163-182. , 1978. Trace fossils in Leg $42 \mathrm{~A}$ cores. In Hsü, K., Montadert, L., et al., Init. Repts. DSDP, 42, Pt. 1: Washington (U.S. Govt. Printing Office), 821-827.

Ernst, W. G., and Calvert, S. E., 1969. An experimental study of the recystallization of porcellanite and its bearing on the origin of some bedded cherts. Am. J. Sci., 267-A:114-133.

Flörke, O. W., 1955. Zur frage des 'Hoch'-cristobalit in opalen, bentoniten und Glasern. N. Jahrb. Mineral., 10:217-223.

Folk, R. L., and MacBride, E. F., 1978. Radiolarites and their relation to subjacent "ocean crust"' in Liguria, Italy. J. Sediment. Petrol., 48:1069-1102.

Folk, R. L., and Pittman, J. S., 1971. Length-slow chalcedony: a new testament for vanished evaporites. J. Sediment. Petrol., 41:10451058.

Garrison, R. E., Rowland, S. M., and Horan, L. J., 1975. Petrology of siliceous rocks recovered from marginal seas of the western Pacific, Leg 31, Deep Sea Drilling Project. In Karig, D. E., Ingle, J. C., Jr., et al., Init. Repts. DSDP, 31: Washington (U.S. Govt. Printing Office), 519-529.
Greenwood, R., 1973. Cristobalite: its relationship to chert formation in selected samples from the Deep Sea Drilling Project. J. Sediment. Petrol., 43:700-708.

Hathaway, J. C., 1972. X-ray mineralogy studies-Leg 11, part 2. In Hollister, C. D., Ewing, J. I., et al., Init. Repts. DSDP, 11: Washington (U.S. Govt. Printing Office), 772-789.

Heath, G. R., 1973. Cherts from the eastern Pacific, Leg 16, Deep Sea Drilling Project. In van Andel, Tj. H., Heath, G. R., et al., Init. Repts. DSDP, 16: Washington (U.S. Govt. Printing Office), 609-613.

Heath, G. R., and Moberly, R., 1971. Cherts from the western Pacific, Leg 7, Deep Sea Drilling Project. In Winterer, E. L., Riedel, W. R., et al., Init. Repts. DSDP, 7, Pt. 2: Washington (U.S. Govt. Printing Office), 991-1007.

Hein, J. R., Scholl, D. W., and Barron, J. A., 1978. Diagenesis of late Cenozoic diatomaceous deposits and formation of the bottom simulating reflector in the southern Bering Sea. Sedimentology, 25:155-181.

Iijima, A., Kakuwa, Y., and Yamazaki, K., 1978. Shallow-sea organic origin of the Triassic bedded chert in central Japan. J. Faculty Sci. Univ. Tokyo, Sec. 2, 19(5):369-400.

Imoto, N., and Saito, Y., 1973. Scanning electron microscopy of chert. Bull. National Sci. Mus., Tokyo, 16(2):397-402.

Jones, J. B., and Segnit, E. R., 1971. The nature of opal nomenclature and constituent phases. J. Geol. Soc. Australia, 18(1):57-68.

Kastner, M., Keene, J. B., and Gieskes, J. M., 1977. Diagenesis of siliceous oozes. I. Chemical controls on the rate of opal-A to opalCT transformation-an experimental study. Geochim. Cosmochim. Acta, 41:1041-1059.

Keene, J. B., 1975. Cherts and porcellanites from the north Pacific, DSDP Leg 32. In Larson, R. L., Moberly, R., et al., Init. Repts. DSDP, 32: Washington (U.S. Govt. Printing Office), 429-507. , 1976. The distribution, mineralogy, and petrography of biogenic and authigenic silica from the Pacific Basin [Ph.D. dissert.]. University of California, San Diego.

Kelts, K. R., 1976. Marcasite in Miocene calcareous sediments from Hole 315A. In Schlanger, S. O., Jackson, E. D., et al., Init. Repts. DSDP, 33: Washington (U.S. Govt. Printing Office), 867-870.

Kennedy, W. J., 1975. Trace fossils in carbonate rocks. In Frey, R. W., (Ed.), The Study of Trace Fossils: New York (SpringerVerlag), pp. 377-398.

Kennedy, W. J., and Garrison, R. E., 1975. Morphology and genesis of nodular chalks and hardgrounds in the Upper Cretaceous of southern England. Sedimentology, 22:311-386.

Klug, H. P., and Alexander, L. E., 1954. X-ray Diffraction Procedures: New York (Wiley).

Lancelot, Y., 1973. Chert and silica diagenesis in sediments from the central Pacific. In Winterer, E. L., Ewing, J. I., et al., Init. Repts. DSDP, 17: Washington (U.S. Govt. Printing Office), $377-405$.

Laurent, E., and Scheere, J., 1971. Les silicites: evolution de la silice. Soc. Belge Geol., Paleont., Hydrol. Bull., 80(3-4):145-158.

Levitan, M. A., and Lisitsyn, A. P., 1977. Electron microscope study of chert from the sedimentary sequence of the central part of the Pacific Ocean. Acad. Sci. U.S.S.R., Oceanol., 16(6):583-585.

McBride, E. F., and Folk, R. L., 1977. The Caballos Novaculite revisited. Part II. Chert and shale members and synthesis. J. Sediment. Petrol., 47:1261-1286.

Milliken, K. L., 1979. The silicified evaporite syndrome-two aspects of silicification history of former evaporite nodules from southern Kentucky and northern Tennessee. J. Sediment. Petrol., 49: 245-256.

Mitsui, K., 1975. Diagenetic alteration of some minerals in argillaceous sediments in western Hokkaido, Japan. Sci. Repts., Tohoku Univ., Series 3, 13:1.

Murata, K. J., and Larson, R. R., 1975. Diagenesis of Miocene siliceous shales, Temblor Range, California. U.S. Geol. Survey J. Res., 3:553-566.

Murata, K. J., and Nakata, J. K., 1974. Cristobalite stage in the diagenesis of diatomaceous shale. Science, 184:567-568.

Murata, K. J., and Norman, M. B., 1976. An index of crystallinity of quartz. Am. J. Sci., 276:1120-1130.

Nilsen, T. H., 1976. Turbidites, redbeds, sedimentary structures, and trace fossils observed in DSDP Leg 38 cores and the sedimentary history of the Norwegian-Greenland Sea. In Talwani, M., Udin- 
tsev, G., et al., Init. Repts. DSDP, 38: Washington (U.S. Govt. Printing Office), 259-288.

Oehler, J. H., 1973. Tridymite-like crystals in cristobalite "cherts." Nature, 241:64-65.

Pisciotto, K. A., 1978. Basinal sedimentary facies and diagenetic aspects of the Monterey Shale, California [Ph.D. dissert.]. University of California, Santa Cruz.

Riech, V., and von Rad, U., 1979. Silica diagenesis in the Atlantic Ocean: diagenetic potential and transformations. In Talwani, M., Hay, W., and Ryan, W. B. F. (Eds.), Deep Drilling Results in the Atlantic Ocean: Continents, Margins, and Paleoenvironments. Maurice Ewing Ser. 3: Washington (Am. Geophys. Union), p. 315-340.

van der Lingen, G. J., 1973. Ichnofossils in deep-sea cores from the southwest Pacific. In Burns, R. E., Andrews, J. E., et al., Init. Repts. DSDP, 21: Washington (U.S. Govt. Printing Office), 693-700.

von Rad, U., Riech, V., and Rösch, H., 1979. Silica diagenesis in continental margin sediments off northwest Africa. In Lancelot, Y., Seibold, E., et al., Init. Repts. DSDP, 41: Washington (U.S. Govt. Printing Office), 879-905.

Wachs, D., and Hein, J. R., 1974. Petrography and diagenesis of Franciscan limestones. J. Sediment. Petrol., 44:1217-1231.

Warme, J. E., Kennedy, W. J., and Schneidermann, N., 1973. Biogenic sedimentary structures (trace fossils) in Leg 15 cores. In Edgar, N. T., Saunders, J. B., et al., Init. Repts. DSDP, 15: Washington (U.S. Govt. Printing Office), 813-831.
Wilson, M. H., Russell, J. D., and Tait, J. M., 1974. A new interpretation of the structure of disordered $\alpha$-cristobalite. Contr. Mineral. Petrol., 47:1-6.

Wise, S. W., and Weaver, F. M., 1974. Chertification of oceanic sediments. In Hsü, K. J., and Jenkyns, H. C. (Eds.), Pelagic Sediments on Land and Under the Sea: Spec. Pub. Internat. Assoc. Sedimentol., 1:301-326.

\section{APPENDIX}

The appendix lists the occurrence and abundance of chert and porcellanite in cores recovered during Leg 62. Depth is to the base of a core. Recovery is in percent of drilled interval. Lithology abbreviations are NO, nannofossil ooze; NC, nannofossil chalk; LS, limestone; SC, siliceous-fossil clay or clayey diatom ooze; BC, brown clay; and $\mathrm{CH}$, chert and porcellanite. The abundance of chert in the core is a qualitative estimate based on the amount and type of recovered sediment, the drilling time, torque and pump pressure of coring as determined from the drilling log, experience of the drilling crew, and discussions with the drilling crew during coring attempts. Rare (R) generally means the recovery of only a few fragments of chert $(<1 \%)$ within a high-recovery calcareous sediment core, or the recovery of a few fragments when other factors indicate the near absence of chert (fast drill time, low torque, low pump pressure). Common (C) shows a higher percentage of chert in the core (1-10\%) and (or) high drill time, high and steady torque, and possibly high pump pressure. Abundant (A) generally indicates that at least $10 \%$ of a drilled sequence consists of chert, as shown by high chert percentages in the recovered sediment, and high drill time, torque, and pump pressure. A dash indicates the absence of chert.

\begin{tabular}{|c|c|c|c|c|c|}
\hline Core & $\begin{array}{l}\text { Sub-bottom } \\
\text { Depth } \\
\text { (m) }\end{array}$ & $\begin{array}{c}\text { Recovery } \\
(\%)\end{array}$ & Lithology & Age of Core & Chert \\
\hline \multicolumn{6}{|c|}{ Hole 463} \\
\hline 1 & 5.5 & 99 & No & Plio.-Pleist. & - \\
\hline 2 & 15.0 & 99 & No & Pliocene & - \\
\hline 3 & 24.5 & 84 & No & L. Mio.-Plio. & - \\
\hline 4 & 34.0 & 98 & No & L. Mio. & - \\
\hline 5 & 38.0 & 75 & No & Oligocene & - \\
\hline 6 & 43.5 & 100 & NO & M. Eoc. and Olig. & $\mathrm{R}$ \\
\hline 7 & 53.0 & 54 & NO, NC & L. Maas. and E. Eoc. & R \\
\hline 8 & 62.5 & 43 & $\mathrm{NC}$ & E. Maas. & c \\
\hline 9 & 72.0 & 46 & NO, NC & E. Maas. & $\mathrm{R}$ \\
\hline 10 & 81.5 & 97 & NO, NC & E. Maas. & $\mathrm{C}$ \\
\hline i1 & 91.0 & 72 & NO, NC & E. Maas. & $\mathbf{R}$ \\
\hline 12 & 100.5 & 95 & NO, NC & E. Maas. & $\ddot{R}$ \\
\hline 13 & 110.0 & 98 & NO, NC & E. Maas. & $\mathbf{R}$ \\
\hline 14 & 119.5 & 69 & NO, NC & E. Maas. & $\ddot{R}$ \\
\hline 15 & 129.0 & 89 & NC & E. Maas. & R \\
\hline 16 & 138.5 & 93 & NC & E. Maas. & R \\
\hline 17 & 148.0 & 100 & NC & E. Maas. & $\mathrm{C}$ \\
\hline 18 & 157.5 & 6 & NC & E. Maas. & $\mathrm{R}$ \\
\hline 19 & 167.0 & 100 & $\mathrm{NO}, \mathrm{NC}$ & E. Maas. & $\ddot{R}$ \\
\hline 20 & 176.5 & 14 & NC & E. Maas. & $\ddot{R}$ \\
\hline 21 & 186.0 & 98 & NC & L. Camp. & $\ddot{R}$ \\
\hline 22 & 195.0 & 70 & NC, NO & L. Camp. & $\mathrm{R}$ \\
\hline 23 & 199.5 & 38 & NC, NO & L. Camp. & $\mathrm{R}$ \\
\hline 24 & 205.0 & 77 & $\mathrm{NC}, \mathrm{NO}$ & L. Camp. & $\mathrm{R}$ \\
\hline 25 & 214.5 & 30 & $\mathrm{NC}, \mathrm{NO}$ & L. Sant,-L. Camp. & R \\
\hline 26 & 224.0 & 93 & $\mathrm{NC}$ & E. Sant. & $\mathrm{R}$ \\
\hline 27 & 233.5 & 25 & $\mathrm{NC}, \mathrm{NO}$ & E. Sant. & $\mathrm{C}$ \\
\hline 28 & 243.0 & 1 & $\mathrm{CH}$ & E. Sant. & $\mathbf{R}$ \\
\hline 29 & 252.5 & 9 & $\mathrm{NC}$ & E. Sant. & $\ddot{R}$ \\
\hline 30 & 262.0 & 32 & NC & E. Sant. & $\mathbf{R}$ \\
\hline 31 & 271.5 & 5 & LS, $\mathrm{CH}$ & L. Tur. & $\mathbf{R}$ \\
\hline 32 & 281.0 & 3 & LS, NC, $\mathrm{CH}$ & L. Tur. & $\mathbf{R}$ \\
\hline 33 & 290.5 & 31 & $\mathrm{NC}, \mathrm{LS}, \mathrm{CH}$ & L. Tur. & C \\
\hline 34 & 300.0 & 43 & $\mathrm{NC}, \mathrm{CH}$ & M. Tur. & C \\
\hline 35 & 309.5 & 4 & NC & E. Tur. & $\mathbf{R}$ \\
\hline 36 & 319.0 & 2 & LS, NC, $\mathrm{CH}$ & E. Tur. & 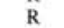 \\
\hline 37 & 328.5 & 0.2 & NC & E. Tur. & R \\
\hline 38 & 338.0 & 9 & NC & E. Tur. & $\hat{\mathrm{R}}$ \\
\hline 39 & 347.5 & 2 & $\mathrm{NC}, \mathrm{CH}$ & L. Cenom. & $\ddot{c}$ \\
\hline 40 & 357.0 & 1 & $\mathrm{CH}, \mathrm{NC}$ & L. Cenom. & $\mathrm{R}$ \\
\hline 41 & 366.5 & i & $\mathrm{CH}$ & L. Cenom. & R \\
\hline 42 & 376.0 & 2 & $\mathrm{CH}, \mathrm{LS}$ & L. Cenom. & R \\
\hline 43 & 385.5 & 67 & $\mathrm{NO}, \mathrm{NC}$ & E. Cenom. & R \\
\hline 44 & 395.0 & 12 & $\mathrm{NC}, \mathrm{CH}$ & E. Cenom. & $\hat{R}$ \\
\hline 45 & 404.5 & 1 & $\mathrm{CH}$ & E. Cenom. & $\mathbf{R}$ \\
\hline 46 & 414.0 & 10 & $\mathrm{CH}$ & L. Albian & $\ddot{c}$ \\
\hline 47 & 423.5 & 1 & $\mathrm{CH}$ & L. Albian & C \\
\hline 48 & 427.5 & 100 & $\mathrm{NC}$ & L. Albian & $\mathrm{R}$ \\
\hline 49 & 433.0 & 1 & $\mathrm{CH}, \mathrm{NC}$ & L. Albian & $\ddot{R}$ \\
\hline 50 & 442.5 & 10 & $\mathrm{NC}, \mathrm{CH}$ & L. Albian & R \\
\hline
\end{tabular}

\begin{tabular}{|c|c|c|c|c|c|}
\hline Core & $\begin{array}{l}\text { Sub-bottom } \\
\text { Depth } \\
\text { (m) }\end{array}$ & $\begin{array}{c}\text { Recovery } \\
(\%)\end{array}$ & Lithology & Age of Core & Chert \\
\hline 51 & 452.0 & 2 & $\mathrm{CH}$ & L. Albian & c \\
\hline 52 & 461.5 & 2 & $\mathrm{CH}, \mathrm{NC}, \mathrm{LS}$ & L. Albian & C \\
\hline 53 & 471.0 & 18 & LS, CH & M. Albian & C \\
\hline 54 & 480.5 & 3 & LS, CH & M. Albian & $\mathbf{R}$ \\
\hline 55 & 490.0 & 10 & LS, CH & E. Albian & $\mathbf{R}$ \\
\hline 56 & 499.5 & 14 & NC, LS, CH & E. Albian & c \\
\hline 57 & 509.0 & 26 & LS, CH & E. Albian & C \\
\hline 58 & 518.5 & 45 & $\mathrm{LS}, \mathrm{CH}$ & E. Albian & A \\
\hline 59 & 528.0 & 49 & LS, CH & E. Albian & A \\
\hline 60 & 535.5 & 78 & LS, $\mathrm{CH}$ & L. Aptian & A \\
\hline 61 & 537.5 & 85 & LS & L. Aptian & $\mathbf{R}$ \\
\hline 62 & 547.0 & 49 & LS & L. Aptian & $R$ \\
\hline 63 & 556.5 & 37 & LS & L. Aptian & $\mathbf{R}$ \\
\hline 64 & 566.0 & 42 & LS & E. Aptian & $\mathbf{R}$ \\
\hline 65 & 575.5 & 35 & $\mathrm{LS}, \mathrm{CH}$ & E. Aptian & C \\
\hline 66 & 585.0 & 35 & LS, CH & E. Aptian & c \\
\hline 67 & 594.5 & 31 & LS, CH & E. Aptian & C \\
\hline 68 & 604.0 & 6 & LS, CH & E. Aptian & C \\
\hline 69 & 613.5 & 38 & LS, CH & E. Aptian & C \\
\hline 70 & 623.0 & 100 & LS & E. Aptian & R \\
\hline 71 & 632.5 & 59 & LS & E. Aptian & $\mathrm{R}$ \\
\hline 72 & 642.0 & 70 & LS & E. Aptian & R \\
\hline 73 & 651.5 & 63 & LS & E. Aptian & - \\
\hline 74 & 661.0 & 22 & LS & E. Aptian & $\mathbf{R}$ \\
\hline 75 & 670.5 & 11 & LS & E. Aptian & $\mathrm{R}$ \\
\hline 76 & 680.0 & 14 & LS, CH & E. Aptian & C \\
\hline 77 & 689.5 & 14 & LS, CH & E. Aptian & c \\
\hline 78 & 699.0 & 15 & LS, CH & E. Aptian & C \\
\hline 79 & 708.5 & 8 & LS, $\mathrm{CH}$ & Barremian & C \\
\hline 80 & 710.5 & 38 & LS & Barremian & R \\
\hline 81 & 718.0 & 31 & LS & Barremian & $\mathbf{R}$ \\
\hline 82 & 727.5 & 14 & LS & Barremian & - \\
\hline 83 & 737.0 & 26 & LS & Barremian & - \\
\hline 84 & 746.5 & 22 & LS & Barremian & $R$ \\
\hline 85 & 756.0 & 35 & LS & Barremian & $R$ \\
\hline 86 & 765.5 & 14 & LS & Barremian & $R$ \\
\hline 87 & 775.0 & 8 & LS & Barremian & R \\
\hline 88 & 784.5 & 6 & LS & Barremian & $\mathrm{R}$ \\
\hline 89 & 794.0 & 12 & LS & Barremian & $\mathbf{R}$ \\
\hline 90 & 803.5 & 2 & LS & Barremian & R \\
\hline 91 & 813.0 & 0.3 & LS & Barremian & $\mathbf{R}$ \\
\hline 92 & 822.5 & 1 & LS, CH & Barremian & $\mathbf{R}$ \\
\hline \multicolumn{6}{|c|}{ Hole 464} \\
\hline 1 & 3.5 & 6 & SC & L. Plio.-Pleist. & - \\
\hline 2 & 13.0 & 100 & SC & E. and L. Pliocene & - \\
\hline 3 & 22.5 & 89 & SC & E. Pliocene & - \\
\hline 4 & 32.0 & 70 & BC & E. Pliocene & - \\
\hline 5 & 41.5 & 76 & $\mathrm{BC}$ & E. Pliocene(?) & - \\
\hline 6 & 51.0 & 100 & $\mathrm{BC}$ & Mixed Eocene, Olig., Miocene(?) & - \\
\hline 7 & 60.5 & 94 & $\mathrm{BC}$ & Paleocene(?) & - \\
\hline 8 & 70.0 & 19 & $\mathrm{BC}$ & Paleocene(?) & - \\
\hline
\end{tabular}


APPENDIX. Continued.

\begin{tabular}{|c|c|c|c|c|c|}
\hline Core & $\begin{array}{l}\text { Sub-bottom } \\
\text { Depth } \\
\text { (m) }\end{array}$ & $\begin{array}{c}\text { Recovery } \\
(\%)\end{array}$ & Lithology & Age of Core & Chert \\
\hline 9 & 79.5 & 63 & $\mathrm{BC}$ & L. Cret.(?) & - \\
\hline 10 & 89.0 & 59 & BC & L. Alb.-Cenom.(?) & $\mathrm{R}$ \\
\hline 11 & 98.5 & 8 & $\mathrm{CH}, \mathrm{LS}$ & L. Alb.-Cenom. & A \\
\hline 12 & 108.0 & 8 & $\mathrm{CH}, \mathrm{LS}$ & L. Alb.-Cenom. & A \\
\hline 13 & 117.5 & 2 & $\mathrm{CH}, \mathrm{LS}$ & L. Alb.-Cenom. & A \\
\hline 14 & 127.0 & 3 & $\mathrm{CH}, \mathrm{LS}$ & L. Alb.-Cenom. & c \\
\hline 15 & 136.5 & 3 & $\mathrm{CH}, \mathrm{LS}$ & L. Alb.-Cenom. & C \\
\hline 16 & 146.0 & 2 & $\mathrm{CH}, \mathrm{LS}$ & L. Alb,-Cenom. & $\mathbf{R}$ \\
\hline 17 & 155.5 & 3 & $\mathrm{CH}, \mathrm{LS}$ & L. Alb.-Cenom. & C \\
\hline 18 & 165.0 & 2 & $\mathrm{CH}, \mathrm{LS}$ & L. Alb.-Cenom. & C \\
\hline 19 & 174.5 & 2 & $\mathrm{CH}$ & M. Albian & $\mathrm{C}$ \\
\hline 20 & 184.0 & 8 & $\mathrm{CH}$ & M. Albian & A \\
\hline 21 & 193.5 & 8 & $\mathrm{CH}, \mathrm{LS}$ & M. Albian & A \\
\hline 22 & 203.0 & 4 & $\mathrm{CH}$ & M. Albian & A \\
\hline 23 & 212.5 & 8 & $\mathrm{CH}$ & M. Albian & C \\
\hline 24 & 222.0 & 2 & $\mathrm{CH}$ & M. Albian & C \\
\hline 25 & 231.5 & 9 & $\mathrm{CH}$ & M. Albian & A \\
\hline 26 & 241.0 & 7 & $\mathrm{CH}$ & M. Albian & $\mathrm{C}$ \\
\hline 27 & 250.5 & 7 & $\mathrm{CH}$ & E. Albian & A \\
\hline 28 & 260.0 & 5 & $\mathrm{CH}$ & E. Albian(?) & A \\
\hline 29 & 269.5 & 11 & $\mathrm{CH}$ & E. Albian & A \\
\hline 30 & 279.0 & 3 & $\mathrm{CH}$ & E. Albian(?) & A \\
\hline 31 & 288.5 & 5 & $\mathrm{CH}$ & E. Albian(?) & A \\
\hline 32 & 298.0 & 8 & $\mathrm{CH}, \mathrm{LS}$ & E. Albian(?) & A \\
\hline 33 & 307.5 & 5 & $\mathrm{CH}$ & E. Albian(?) & $\mathrm{c}$ \\
\hline 34 & 308.5 & 20 & Basalt & $?$ & - \\
\hline \multicolumn{6}{|c|}{ Hole 465} \\
\hline 1 & 1.0 & 89 & NO & Plio.-Pleist. & - \\
\hline 2 & 10.5 & 88 & NO & Plio.-Pleist. & $\mathbf{R}$ \\
\hline 3 & 20.0 & 63 & NO & L. Paleo. & $\widehat{R}$ \\
\hline 4 & 29.5 & 58 & NO & L. Paleo, & $\overrightarrow{\mathrm{R}}$ \\
\hline 5 & 39.0 & 90 & NO & L. Paleo. & $\mathbf{R}$ \\
\hline 6 & 48.5 & 73 & NO & L. Paleo. & $\mathbf{R}$ \\
\hline 7 & 58.0 & 1 & $\mathrm{NO}, \mathrm{CH}$ & L. Paleo. & $\hat{R}$ \\
\hline 8 & 67.5 & 0.4 & $\mathrm{NO}, \mathrm{CH}$ & E. Paleo., L. Maas. & $\ddot{R}$ \\
\hline 9 & 77.0 & 1 & $\mathrm{CH}$ & E. Paleo., L. Maas. & C \\
\hline 10 & 86.5 & 78 & $\mathrm{NO}, \mathrm{CH}$ & E. Paleo., L. Maas. & $\mathbf{R}$ \\
\hline 11 & 96.0 & 0.3 & $\mathrm{NO}, \mathrm{CH}$ & E. Paleo., L. Maas. & R \\
\hline \multicolumn{6}{|c|}{ Hole 465A } \\
\hline 1 & 48.5 & 16 & NO & L. Paleo. & $\mathbf{R}$ \\
\hline 2 & 58.0 & 0.2 & $\mathrm{NO}, \mathrm{CH}$ & L. Paleo. & $\ddot{R}$ \\
\hline 3 & 67.5 & 87 & NO & E. Paleo., L. Maas. & $\mathbf{R}$ \\
\hline 4 & 77.0 & 1 & $\mathrm{NO}, \mathrm{CH}$ & L. Maas. & $\ddot{R}$ \\
\hline 5 & 86.5 & 0 & ? & ? & - \\
\hline 6 & 96.0 & 1 & $\mathrm{CH}$ & E. Maas. & C \\
\hline 7 & 105.5 & 8 & $\mathrm{NO}, \mathrm{CH}$ & E. Maas. & c \\
\hline 8 & 115.0 & 7 & NO & E. Maas. & $\mathbf{R}$ \\
\hline 9 & 124.5 & 85 & NO & E. Maas. & $\mathbf{R}$ \\
\hline 10 & 134.0 & 40 & NO & E. Maas. & $\ddot{\mathbf{R}}$ \\
\hline 11 & 143.5 & 67 & NO & E. Maas. & $\mathbf{R}$ \\
\hline 12 & 153.0 & 25 & No & E. Maas. & $\widehat{\mathbf{R}}$ \\
\hline 13 & 162.5 & 3 & $\mathrm{CH}$ & E. Maas., L. Camp. & C \\
\hline 14 & 172.0 & 1 & $\mathrm{CH}$ & L. Camp. & c \\
\hline 15 & 181.5 & 48 & NO & L. Camp. & $\mathbf{R}$ \\
\hline 16 & 191.0 & 60 & NO & L. Camp. & $\mathbf{R}$ \\
\hline 17 & 200.5 & 25 & NO & L. Camp. & $\ddot{\mathbf{R}}$ \\
\hline 18 & 210.0 & 21 & NC & L. Camp. & $\hat{\mathrm{R}}$ \\
\hline 19 & 219.5 & 29 & $\mathrm{NO}, \mathrm{NC}$ & L. Camp. & $\vec{R}$ \\
\hline 20 & 229.0 & 37 & NO & E. Camp., Sant. & $\hat{R}$ \\
\hline 21 & 238.5 & 24 & NO & E. Camp., Sant. & $\ddot{R}$ \\
\hline
\end{tabular}

APPENDIX. Continued.

\begin{tabular}{|c|c|c|c|c|c|}
\hline Core & $\begin{array}{c}\text { Sub-bottom } \\
\text { Depth } \\
\text { (m) }\end{array}$ & $\begin{array}{c}\text { Recovery } \\
(\%)\end{array}$ & Lithology & Age of Core & Chert \\
\hline 22 & 248.0 & 1 & $\mathrm{NO}, \mathrm{CH}$ & E. Camp., Sant. & $\begin{array}{l}R \\
R\end{array}$ \\
\hline 23 & 257.5 & 2 & & E. Sant.(?) & $\begin{array}{l}\mathrm{R} \\
\mathrm{R}\end{array}$ \\
\hline $\begin{array}{l}24 \\
25\end{array}$ & $\begin{array}{l}267.0 \\
276.5\end{array}$ & 1 & $\mathrm{NO}, \mathrm{NC}$ & $\begin{array}{l}\text { L. Tur,, E. Coniac. } \\
\text {. Tur., E. Coniac. }\end{array}$ & $\begin{array}{l}R \\
R\end{array}$ \\
\hline 26 & $\begin{array}{l}276.5 \\
286.0\end{array}$ & $\begin{array}{c}1 \\
13\end{array}$ & $\begin{array}{l}\text { LS } \\
\text { LS }\end{array}$ & $\begin{array}{l}\text { L. Tur., E. Coniac. } \\
\text { L. Cenom. }\end{array}$ & $\begin{array}{l}\mathrm{K} \\
\mathrm{R}\end{array}$ \\
\hline 27 & 295.5 & 27 & LS & L. Cenom. & $\mathrm{R}$ \\
\hline 28 & 305.0 & 22 & LS & L. Albian & $\mathrm{R}$ \\
\hline 29 & 314.5 & 25 & $\mathrm{LS}, \mathrm{CH}$ & L. Albian & c \\
\hline 30 & 324.0 & 6 & $\mathrm{LS}, \mathrm{CH}$ & L. Albian & c \\
\hline 31 & 333.5 & 4 & LS, $\mathrm{CH}$ & L. Albian & c \\
\hline 32 & 343.0 & 16 & LS & L. Albian & $\mathrm{R}$ \\
\hline 33 & 352.5 & 32 & is & L. Albian & R \\
\hline 34 & 362.0 & 23 & is & L. Albian & $R$ \\
\hline 35 & 371.5 & 6 & is & L. Albian & $R$ \\
\hline 36 & 381.0 & 34 & is & L. Albian & $R$ \\
\hline 37 & 390.5 & 25 & is & L. Albian & $R$ \\
\hline 38 & 400.0 & 40 & LS & L. Albian & $R$ \\
\hline 39 & 409.5 & 26 & LS & L.. Albian & R \\
\hline 40 & 419.0 & 32 & LS, Trachyte & L. Albian & $\mathrm{R}$ \\
\hline 41 & 428.5 & 32 & Trachyte & $?$ & - \\
\hline 42 & 438.0 & 38 & Trachyte & $?$ & - \\
\hline 43 & 447.5 & 21 & Trachyte & $?$ & - \\
\hline 44 & 457.0 & 37 & Trachyte & $?$ & - \\
\hline 45 & 466.5 & 63 & Trachyte & $?$ & $\bar{z}$ \\
\hline 46 & 476.0 & 35 & Trachyte & $?$ & - \\
\hline \multicolumn{6}{|c|}{ Hole 466} \\
\hline 1 & 8.0 & 100 & No & Pleist. & - \\
\hline 2 & $\begin{array}{l}17.5 \\
270\end{array}$ & $\begin{array}{l}100 \\
84\end{array}$ & $\begin{array}{l}\text { NO } \\
\text { NO }\end{array}$ & Pleist. & $=$ \\
\hline${ }_{4}^{3}$ & $\begin{array}{l}27.0 \\
36.5\end{array}$ & $\begin{array}{l}84 \\
35\end{array}$ & $\begin{array}{l}\text { No } \\
\text { No }\end{array}$ & $\begin{array}{l}\text { L. Plio. } \\
\text { Plio. }\end{array}$ & $\bar{z}$ \\
\hline $\begin{array}{l}{ }_{5}^{4} \\
-\end{array}$ & $\begin{array}{l}36.3 \\
46.0\end{array}$ & 80 & $\begin{array}{l}\text { No } \\
\text { NO }\end{array}$ & $\begin{array}{l}\text { L. Plio. } \\
\text { E. Plio. }\end{array}$ & $\bar{z}$ \\
\hline 6 & 55.5 & 99 & No & E. Plio. & - \\
\hline 7 & 65.0 & 99 & No & E. Plio. & - \\
\hline 8 & 74.5 & 94 & No & L. Eocene & $\mathbf{R}$ \\
\hline 9 & 84.0 & 69 & No & L. Eocene & $\hat{\mathrm{R}}$ \\
\hline 10 & 88.0 & 5 & No & M. Eocene & $\hat{\mathrm{R}}$ \\
\hline 11 & 93.5 & 29 & No & E. Maas., L. Camp. & $\hat{\mathrm{R}}$ \\
\hline 12 & $\begin{array}{r}103.0 \\
\end{array}$ & 12 & No & L. Camp. & $\hat{R}$ \\
\hline 13 & 112.5 & 89 & No & L. Camp. & $\hat{\mathrm{R}}$ \\
\hline 14 & 122.0 & 10 & No & L. Camp. & $\hat{R}$ \\
\hline 15 & 131.5 & 74 & No & L. Camp. & $\hat{\mathrm{R}}$ \\
\hline 16 & 141.0 & 47 & No & E. Sant. & $\hat{R}$ \\
\hline 17 & 150.5 & 16 & No & E. Sant. & $\hat{R}$ \\
\hline 18 & 160.0 & 3 & NO, $\mathrm{CH}$ & E. Sant. & $\mathrm{R}$ \\
\hline 19 & 169.5 & 2 & $\mathrm{CH}$ & E. Sant. & $\hat{R}$ \\
\hline 20 & 179.0 & 2 & $\mathrm{CH}$ & E. Sant. & $\mathrm{R}$ \\
\hline 21 & 188.5 & 2 & $\mathrm{CH}$ & E. Sant. & $\hat{R}$ \\
\hline 22 & 198.0 & $i$ & $\mathrm{CH}$ & $?$ & $\mathrm{R}$ \\
\hline 23 & 207.5 & 2 & $\mathrm{CH}$ & $?$ & $R$ \\
\hline 24 & 217.0 & 2 & $\mathrm{CH}$ & Coniac., L. Tur. & c \\
\hline 25 & 226.5 & 3 & $\mathrm{CH}$ & Coniac,, L. Tur. & c \\
\hline 26 & 236.0 & 5 & $\mathrm{CH}$ & $?$ & c \\
\hline 27 & 245.5 & i & $\mathrm{CH}$ & ? & A \\
\hline 28 & 255.0 & 3 & $\mathrm{NC}, \mathrm{CH}$ & $?$ & A \\
\hline 29 & 264.5 & 25 & NC & E. Cenom., L. Alb. & $R$ \\
\hline 30 & 274.0 & 12 & NC, LS & E. Cenom., L. Alb. & $\mathrm{R}$ \\
\hline 31 & 283.5 & 2 & LS, CH & E. Cenom., L. Alb. & - \\
\hline 32 & 287.5 & 0 & & E. Cenom., L. Alb. & - \\
\hline 33 & 293.0 & 0 & LS, $\mathrm{CH}$ & E. Cenom., L. Alb. & $\mathrm{R}$ \\
\hline 34 & 302.5 & 28 & LS & L. Albian & $\mathrm{R}$ \\
\hline 35 & 312.0 & 10 & LS & L. Albian & $\mathbf{R}$ \\
\hline
\end{tabular}



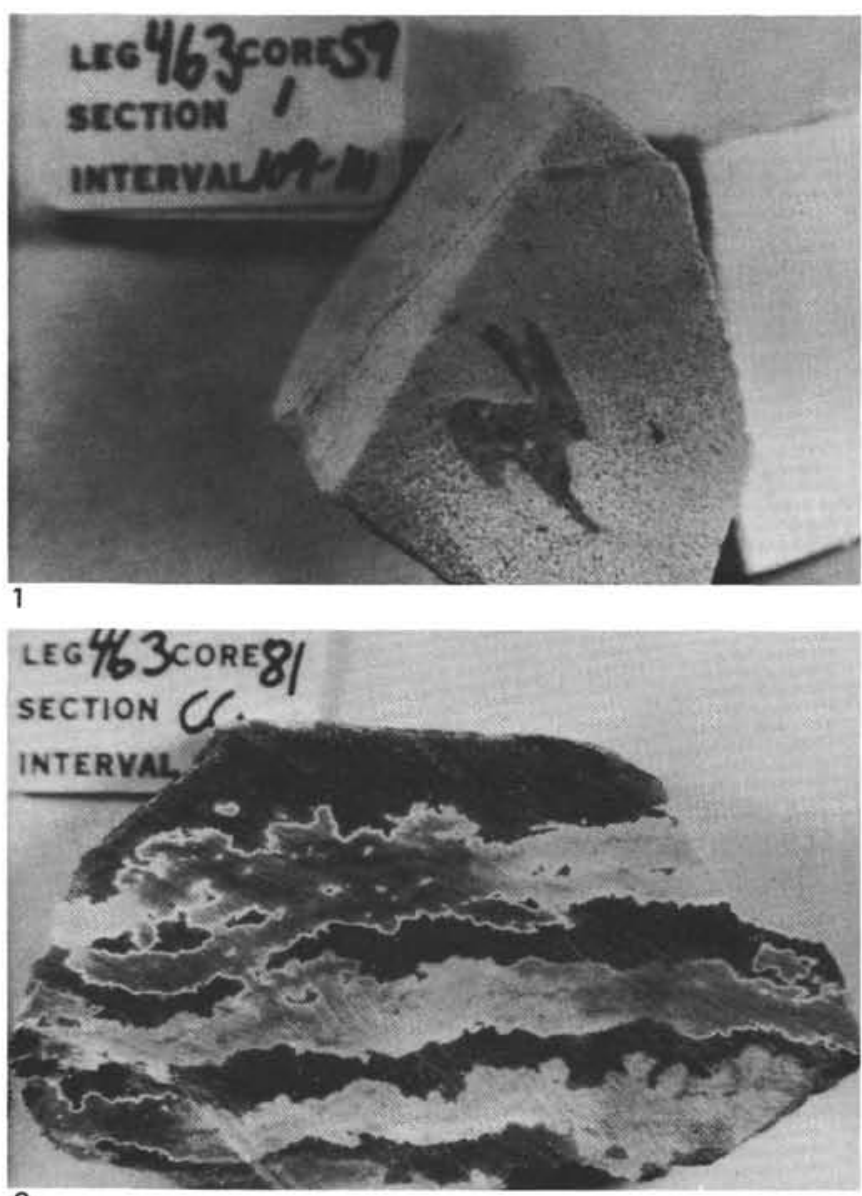

3

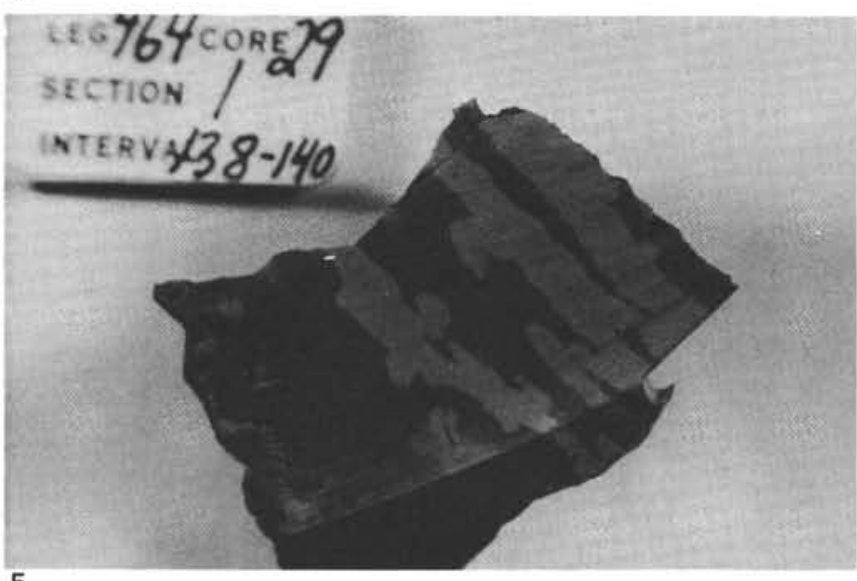

5

Plate 1. Photographs of chertified burrows; length of the label in each photograph is $2.2 \mathrm{~cm}$.

Figure 1. Chert burrow in siliceous chalk. Burrow consists of quartz and calcite with minor opal-CT, the host chalk is mainly calcite and quartz with minor opal-CT.

Figure 2. Chert burrow in siliceous chalk. Burrow is quartz, transition zone is major quartz with minor opal-CT, and chalk is major calcite with moderate quartz and opal-CT.
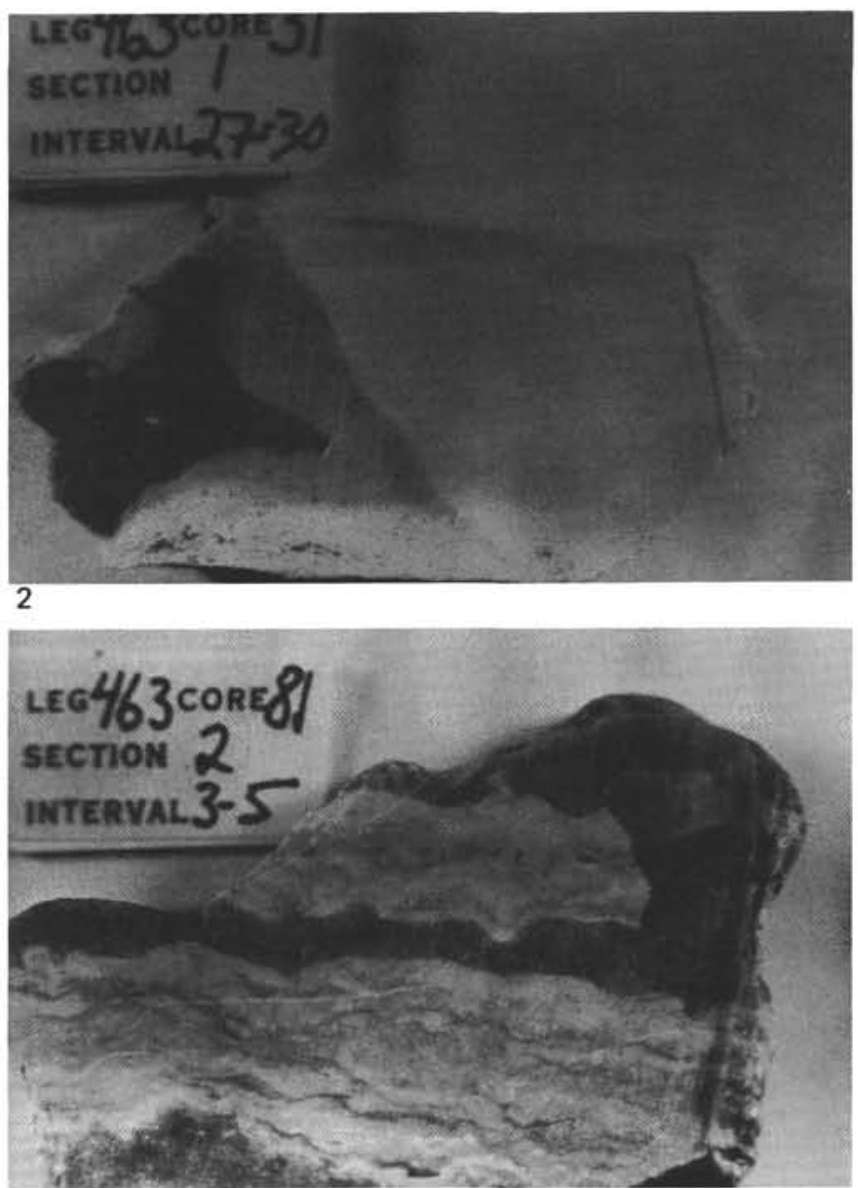

4

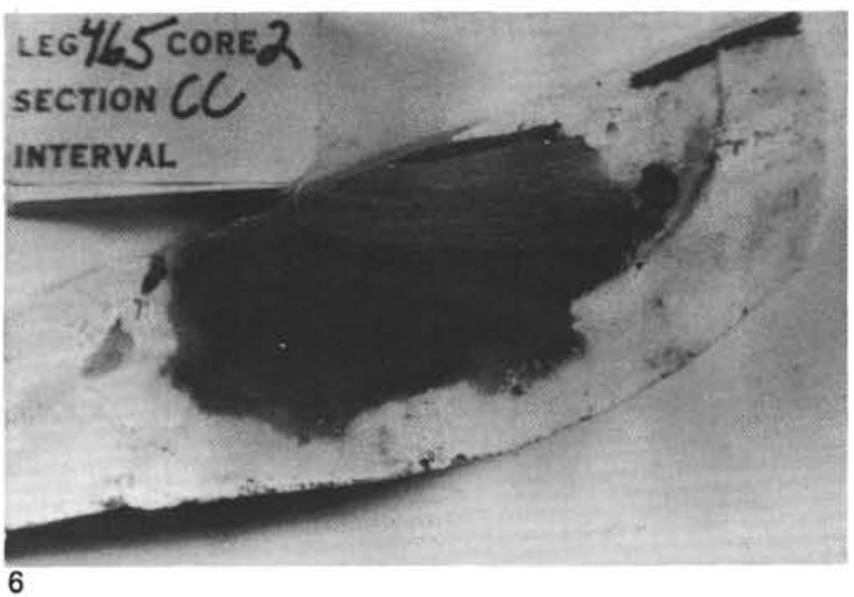

Figure 3. Interbedded dark gray calcareous chert with white chert. Bedding is highly modified by burrowing. See Figure 4A for a detailed drawing of this chert.

Figure 4. Wavy laminations in light-and dark-gray chert; laminations are modified by burrowing.

Figure 5 . Medium- to dark-brown bedded chert; bedding extensively modified by burrowing. See Figure $4 \mathrm{C}$ for a detailed drawing of this chert.

Figure 6. Gray, translucent chert surrounded by white quartz porcellanite. The chert contains silica replacements of sulfate minerals. See text for a discussion of this chert. 

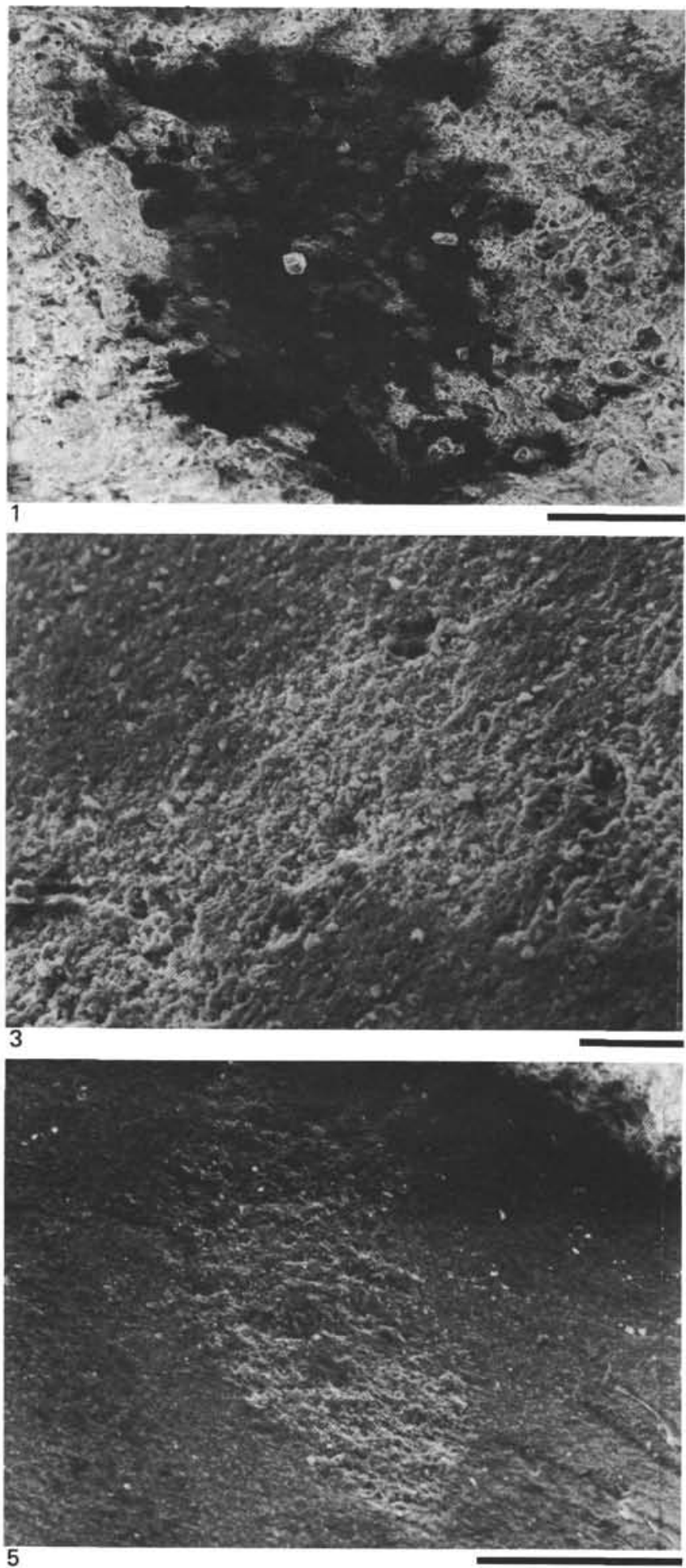

Plate 2. SEM photomicrographs of burrows.

Figure 1. 463-13-6, $98 \mathrm{~cm}$; quartz-chert burrow in siliceous chalk. The burrow fill has been completely silicified, but not completely converted to dense chert. Scale is $300 \mu \mathrm{m}$.

Figure 2. 463-81,CC; reburrowed burrow in a dark-gray calcareous chert, interbedded with white chert. The interior of the burrow contains $\mathrm{Si}$ (by EDAX); the rind $\mathrm{Si}$, trace $\mathrm{Ca}, \mathrm{Al}$; the host chert, $\mathrm{Si}$, trace Ca. Scale is $300 \mu \mathrm{m}$.

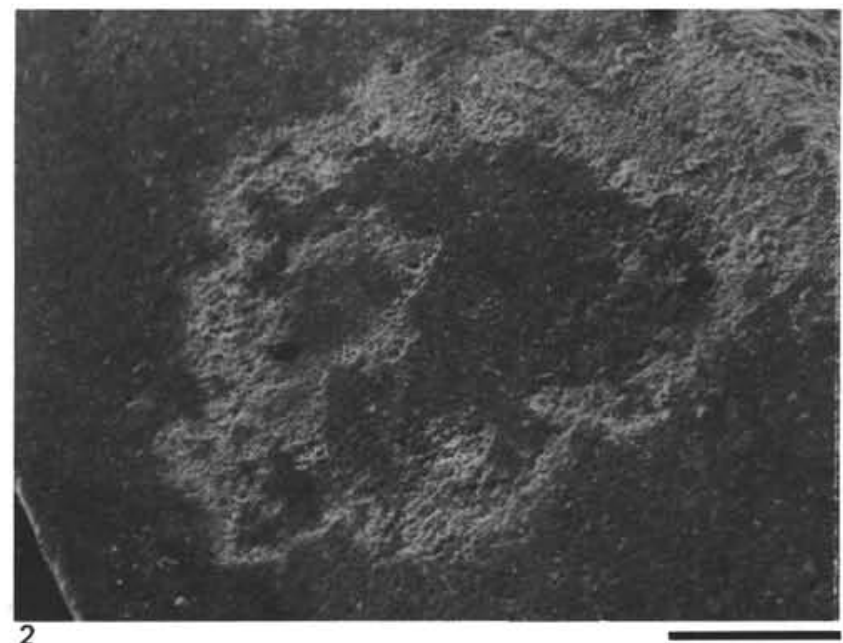

2

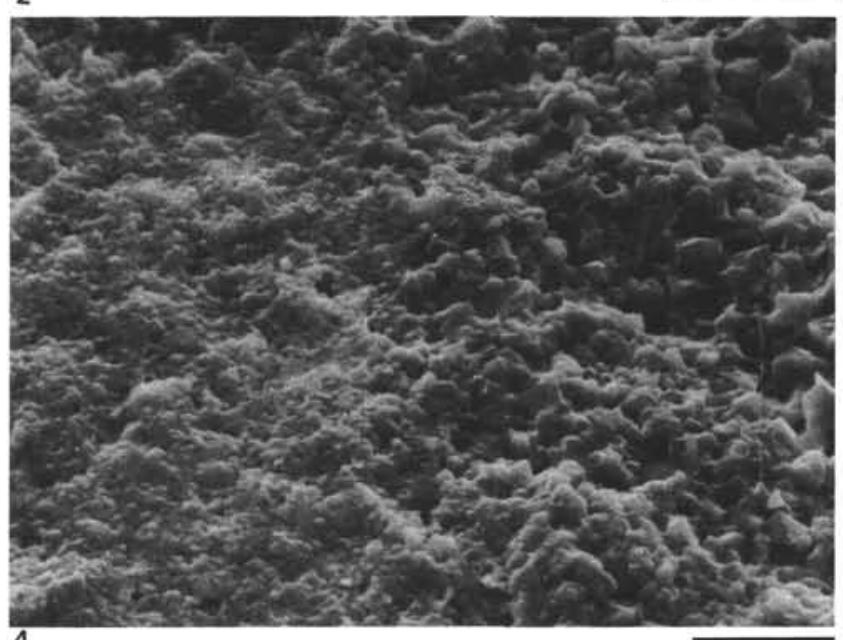

4

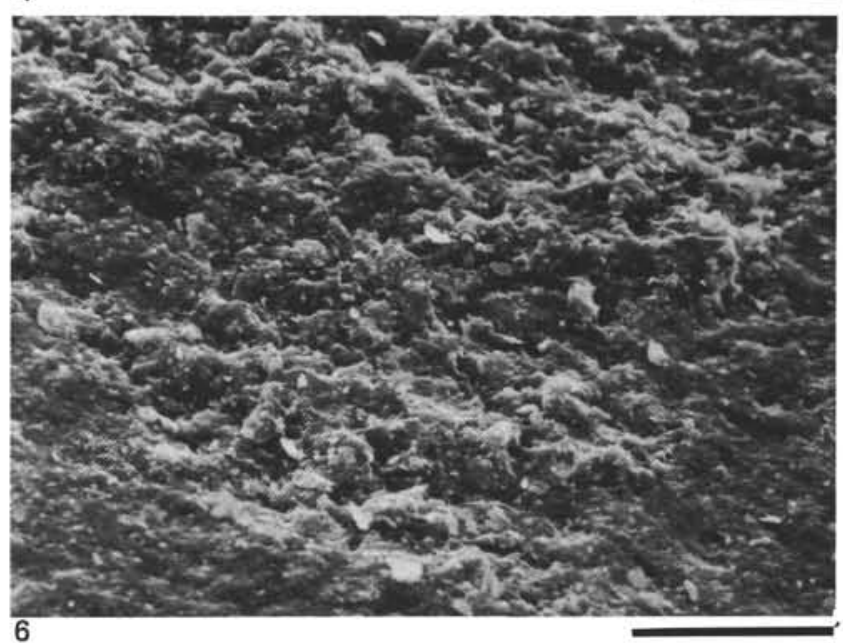

Figure 3. Close-up of burrow rim in Figure 2 i inside of burrow is to the lower right. Note quartz-filled microfossil at edge of rim (upper center). Scale is $60 \mu \mathrm{m}$.

Figure 4. 464-10-4, $91 \mathrm{~cm}$; dark-brown chert; very sharp boundary between host chert (left) and chert burrow composed of coarsegrained quartz crystals (right). Scale is $20 \mu \mathrm{m}$.

Figure 5. 465-13-1, $10 \mathrm{~cm}$; chert with coarser-grained ellipsoidal burrow. Note edge of quartz porcellanite in upper right corner. Scale is $100 \mu \mathrm{m}$.

Figure 6. Close-up of lower part of burrow in Figure 5. Scale is 30 $\mu \mathrm{m}$. 

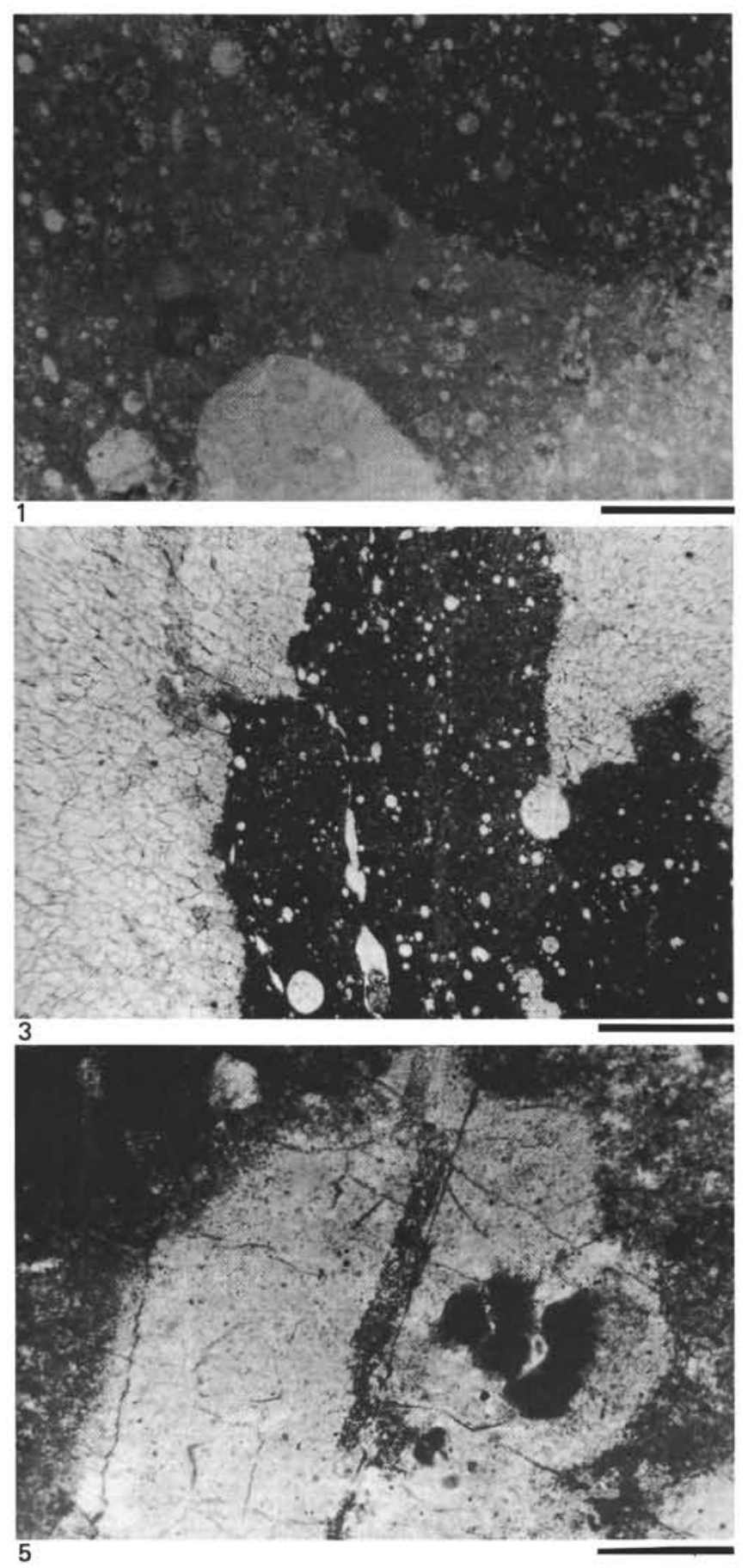

Plate 3. Thin-section photomicrographs of burrows.

Figure 1. 463-60-1, $30 \mathrm{~cm}$; finger-shaped burrow (bottom center) replaced by opal-CT in a siliceous-chalk host. Plane light, scale is $0.64 \mathrm{~mm}$.

Figure 2. As in Figure 1. Crossed nicols. Note that burrow is salted with fine-grained calcite. Radiolarians are filled by calcite.

Figure 3. 463-81, CC; burrowed bedding contact of chert shown in Plate 1, Figure 3. Radiolarians in the carbonate bed (center) are filled with microquartz. Plane light; scale is $0.64 \mathrm{~mm}$.
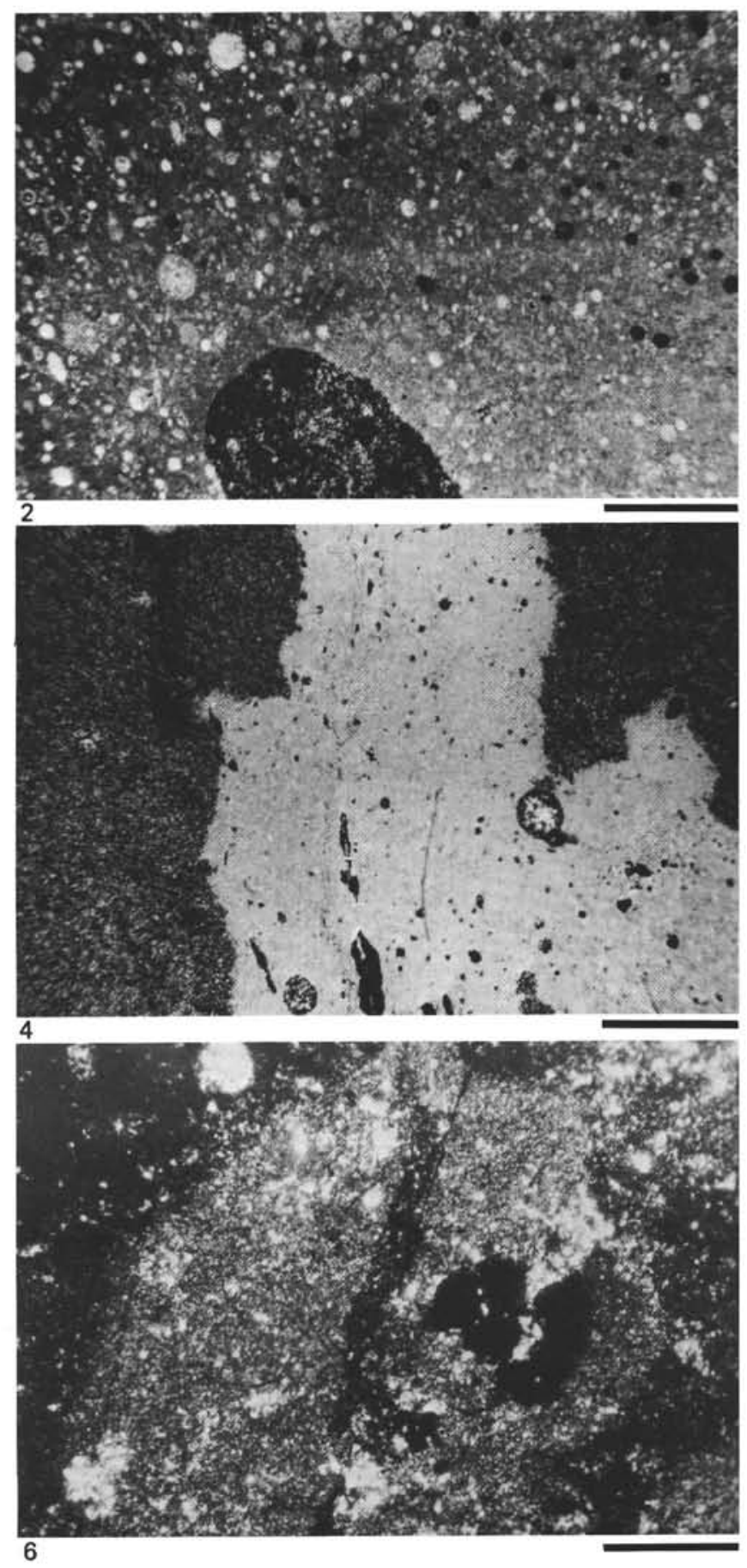

Figure 4. As in Figure 3. Crossed nicols.

Figure 5. 464-29-1, $65 \mathrm{~cm}$; hematite-rimmed quartz burrow (center) in a hematite-rich radiolarian chert (left). Plane light; scale is 0.16 $\mathrm{mm}$.

Figure 6. As in Figure 5. Crossed nicols. All dark areas are hematite, except the dark band trending $\mathrm{N}-\mathrm{S}$ through the quartz burrow, which is pyrite. Radiolarian molds are filled with microquartz and chalcedony. 

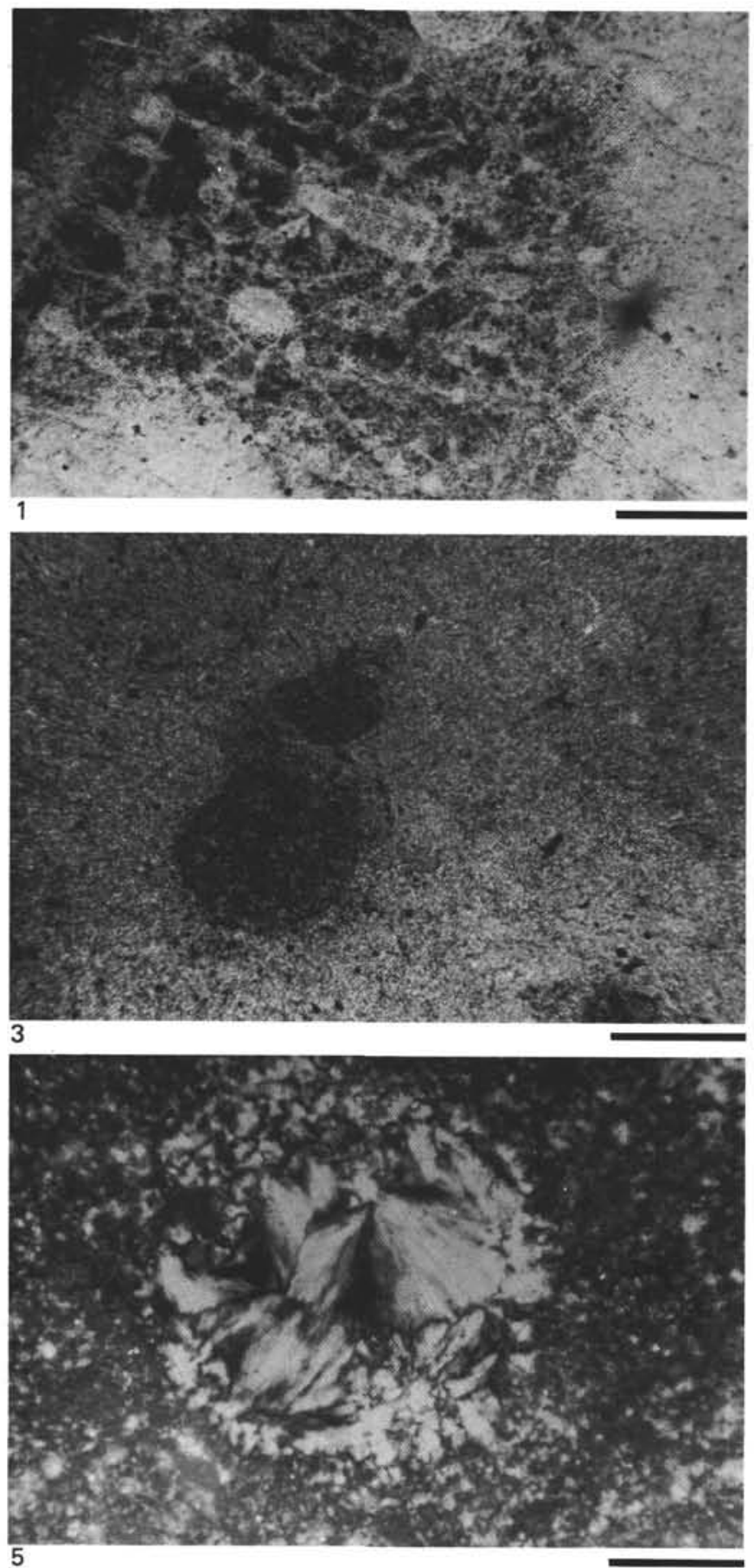

Plate 4. Thin-section photomicrographs of burrows and microfossils.

Figure 1. 463-45,CC \#1; quartz burrow containing much debris, including Fe-oxides, clays, and microfossils (center) in chert (right and lower left). The foraminfer (center) is filled with opal-CT. Plane light; scale is $0.16 \mathrm{~mm}$.

Figure 2. 463-45, CC \#2; circular, inclusion-free, pure-microquartz burrow $(0.7 \mathrm{~mm}$ in diameter; top center) in chert. This burrow is about the same size as the dirty burrow shown in Figure 1. Burrow is adjacent to inclusion-rich opal-CT rim, which is also in contact with siliceous chalk at the far right. Crossed nicols; scale is 0.64 $\mathrm{mm}$.
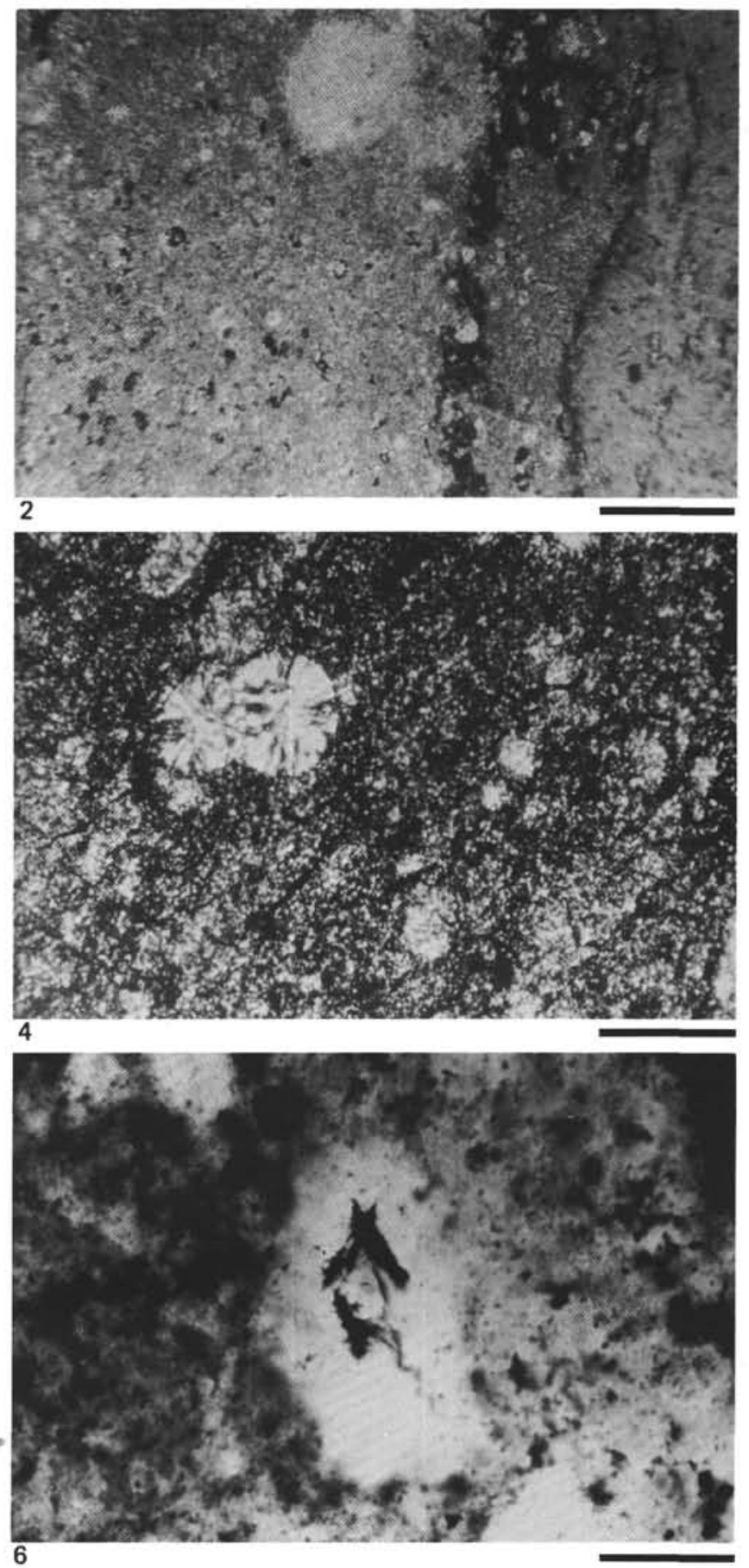

Figure 3. 465A-25,CC; small, circular, Fe-stained burrow in a chert host of uniform clean microquartz. Burrow is free of clays and other debris. Crossed nicols; scale is $0.64 \mathrm{~mm}$.

Figure 4. 465A-26-1, $91 \mathrm{~cm}$; black, Fe-oxide-rich chert containing radiolarians filled with microquartz and chalcedony. Quartz in the two large radiolarians (upper left) consists of radiating bars, in contrast to the more common radiating fibers of chalcedony. Crossed nicols; scale is $0.16 \mathrm{~mm}$.

Figure 5. 464-17,CC; radiolarians filled with both microquartz and chalcedony; test was also replaced by microquartz; in a yellowbrown to red-brown jasper. Crossed nicols; scale is $0.04 \mathrm{~mm}$.

Figure 6. 464-29-1, $138 \mathrm{~cm}$; Fe-Mn needles in clean microquartz radiolarian mold. Host chert is peppered with iron oxides. Plane light; scale is $0.04 \mathrm{~mm}$. 

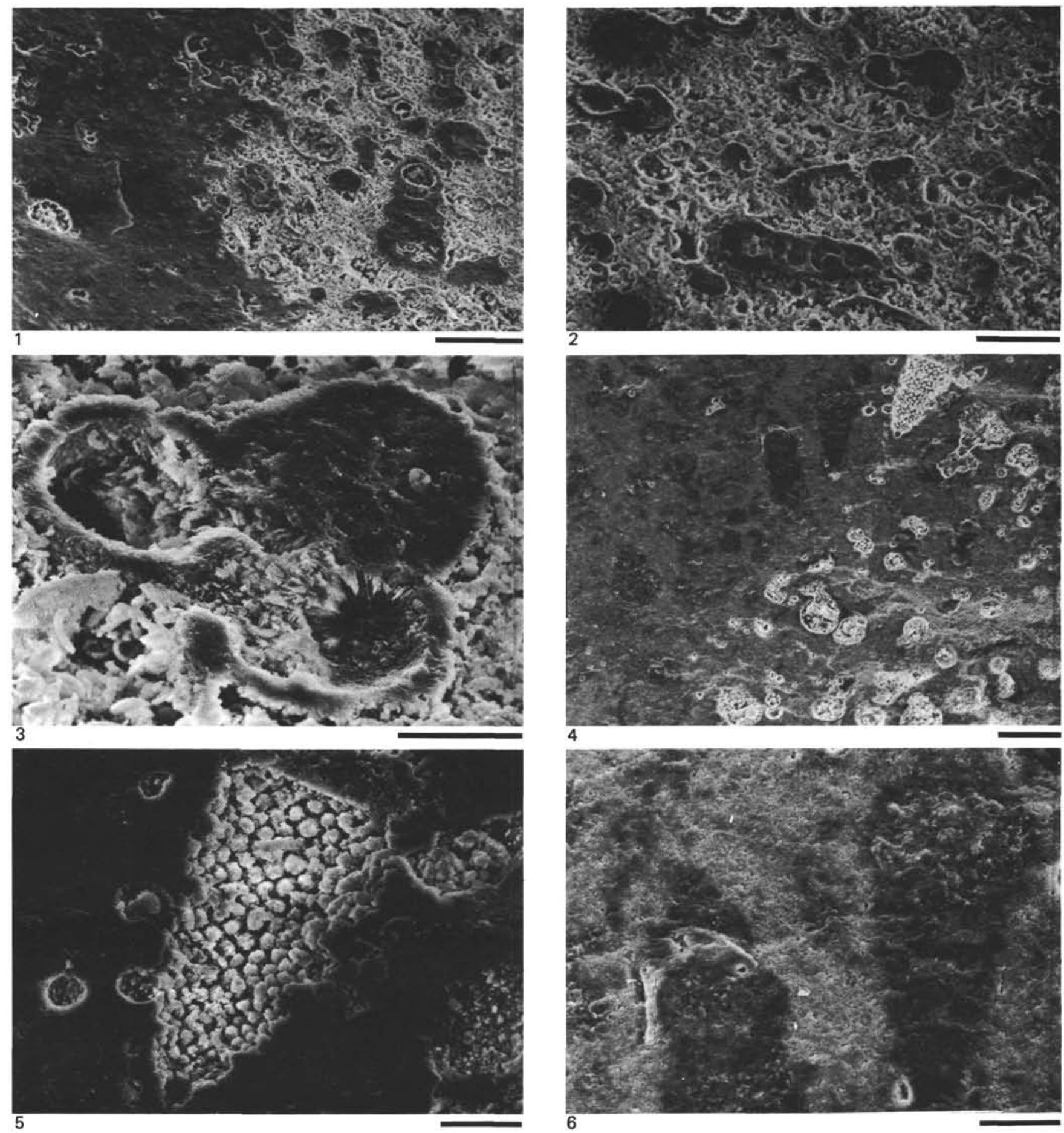

Plate 5. SEM photomicrographs of microfossils. Figures 1-3 represent 463-9-3, $50 \mathrm{~cm}$. Figures 4-6 represent 463-22, CC; sharp contact between brown chert and gray quartz porcellanite. Note the difference in porosity of this quartz porcellanite and the one in Figure 2. The difference is partly due to more radiolarians (a greater source of silica) in the denser porcellanite.

Figure 1. Sharp contact between brown chert (left) and white quartz porcellanite (right). In the chert, microfossils are ghosts, and impressions are in places filled with quartz which has replaced opal-CT blades. Scale is $100 \mu \mathrm{m}$.

Figure 2. Close-up of quartz porcellanite. Foraminifers and radiolarians are replaced by quartz and filled with quartz and opal-CT . Scale is $60 \mu \mathrm{m}$.

Figure 3. Close-up of foraminifer in upper right of Figure 2, showing four chambers, two filled with opal-CT blades, one with massive quartz, and one with silica which has replaced carbonate debris, including coccoliths (lower left). The foraminifer test is replaced by quartz (EDAX shows only Si). Scale is $20 \mu \mathrm{m}$. The porous quartz porcellanite was a chalk that has been completely replaced by and cemented with silica.

Figure 4. Microfossils in the chert are dark ghosts, and in the porcellanite are quartz that has replaced opal-CT lepispheres. Scale is $100 \mu \mathrm{m}$.

Figure 5. Close-up of opal-CT lepispheres replaced by quartz filling the radiolarian at the top right of Figure 4. Scale is $30 \mu \mathrm{m}$.

Figure 6. Close-up of recrystallized quartz radiolarian ghosts (dark areas) at top-center of Figure 4 . Scale is $30 \mu \mathrm{m}$. The quartz porcellanite in Figure 4 has nearly been transformed into a chert. 

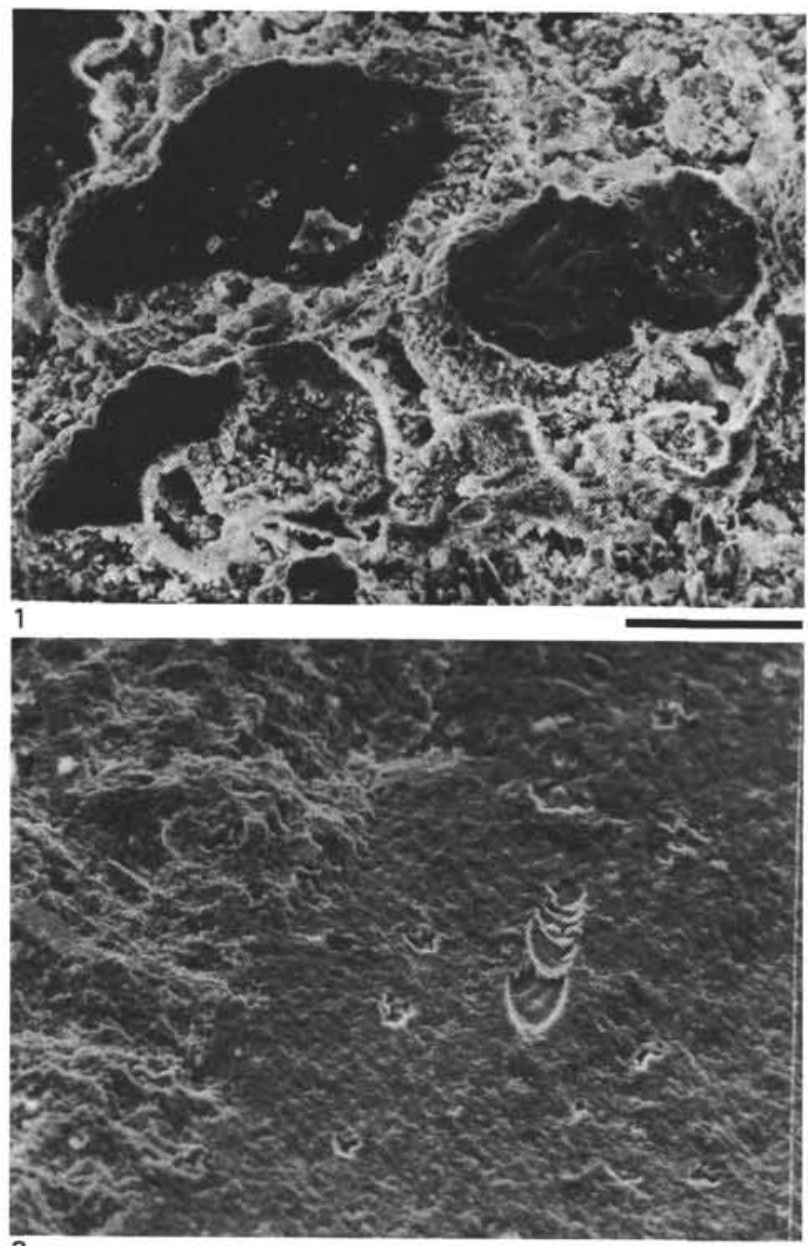

3

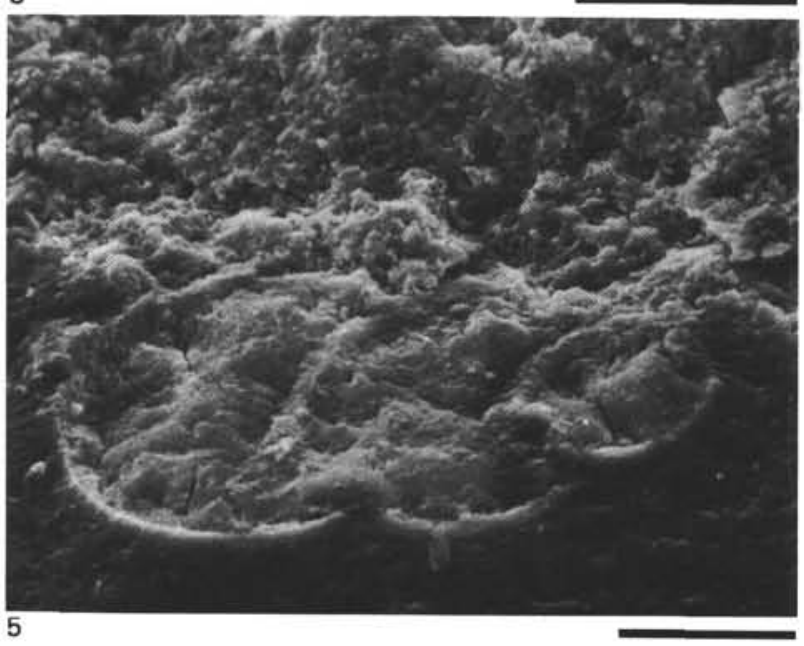

5
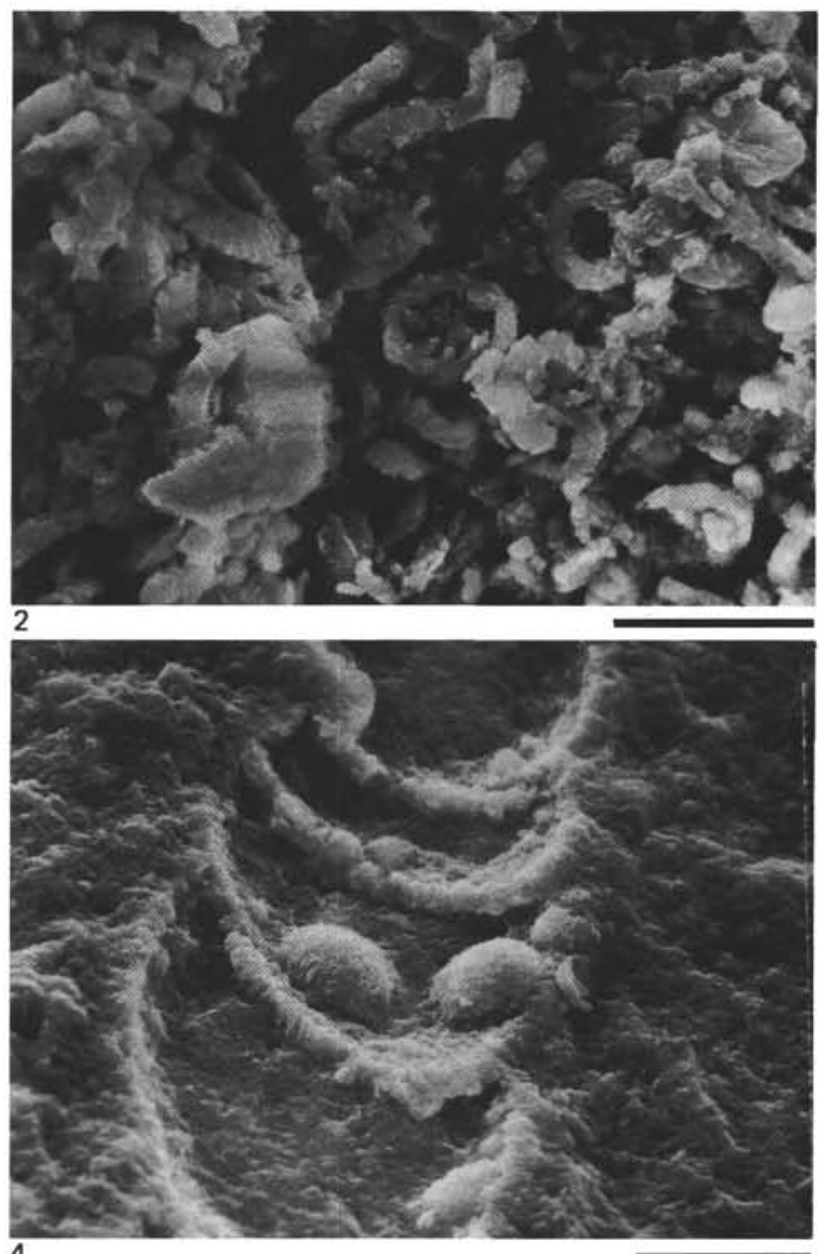

4

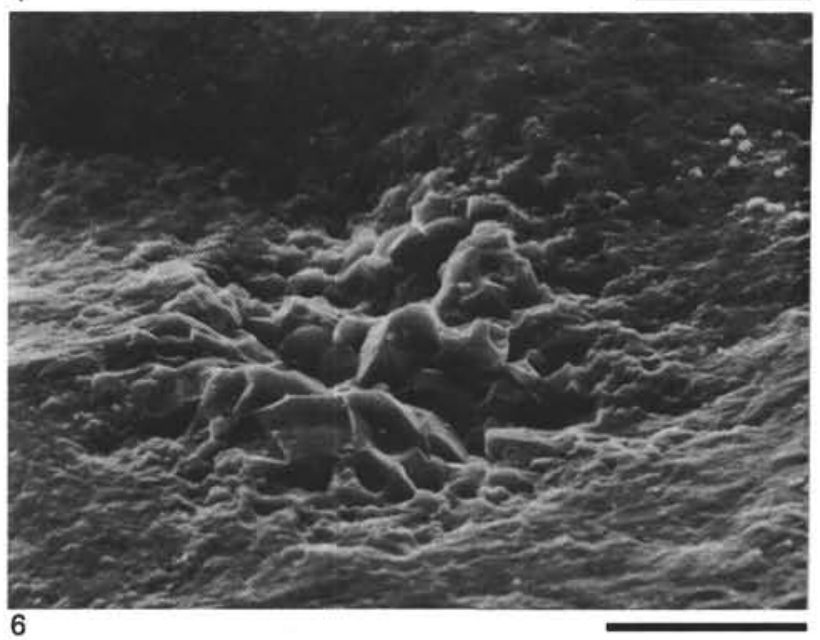

precipitated into voids. Note the foraminifer impression in the chert. Scale is $200 \mu \mathrm{m}$.

Figure 4. Close-up of foraminifer replaced by quartz, containing two masses of quartz that were probably opal-CT lepispheres. Scale is $20 \mu \mathrm{m}$.

Figure 5. 463-81,CC; foraminifer at contact between quartz porcellanite (completely silicified chalk) and chert. The foraminifer mold is filled by massive quartz, and most of the cell wall is gone. Scale is $30 \mu \mathrm{m}$.

Figure 6. 463-81,CC; radiolarian mold filled with relatively coarse microquartz, the most common form of radiolarians in cherts in advanced stages of diagenesis. Scale is $30 \mu \mathrm{m}$. 

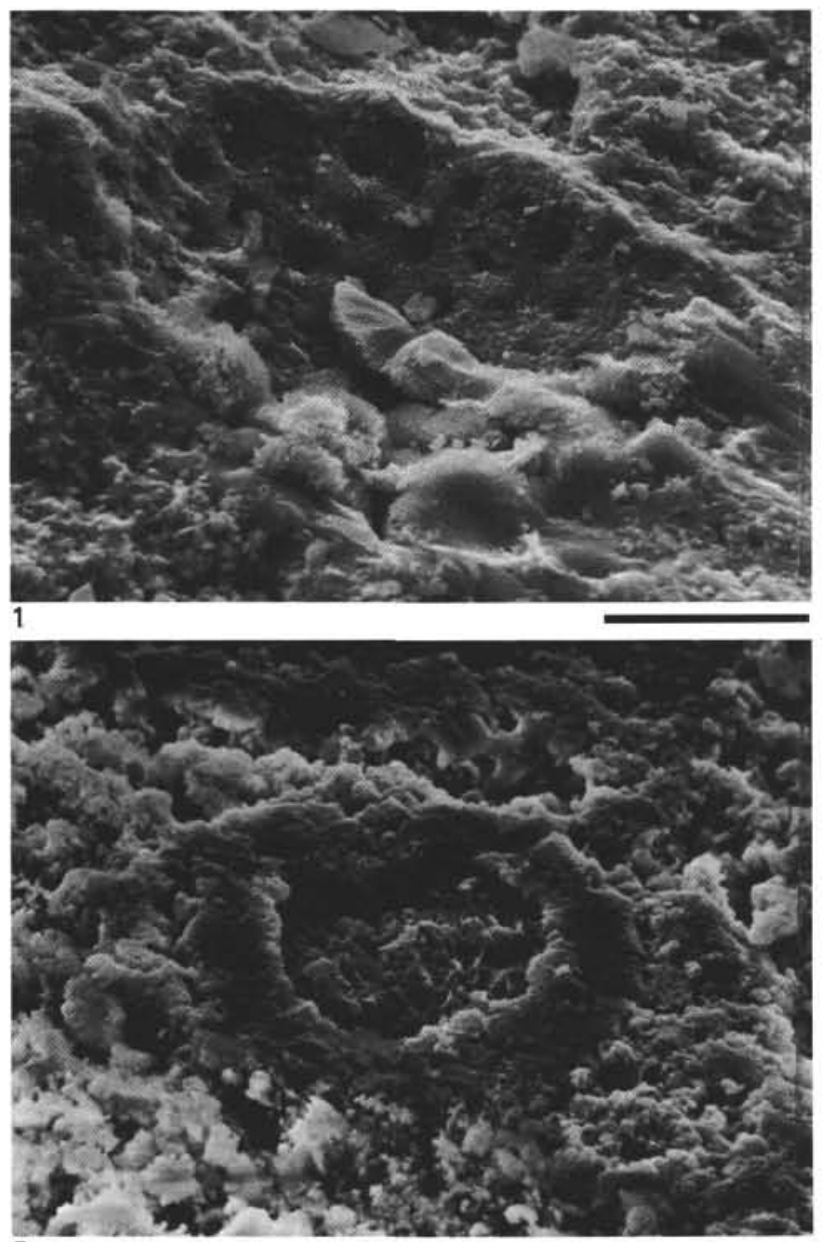
3

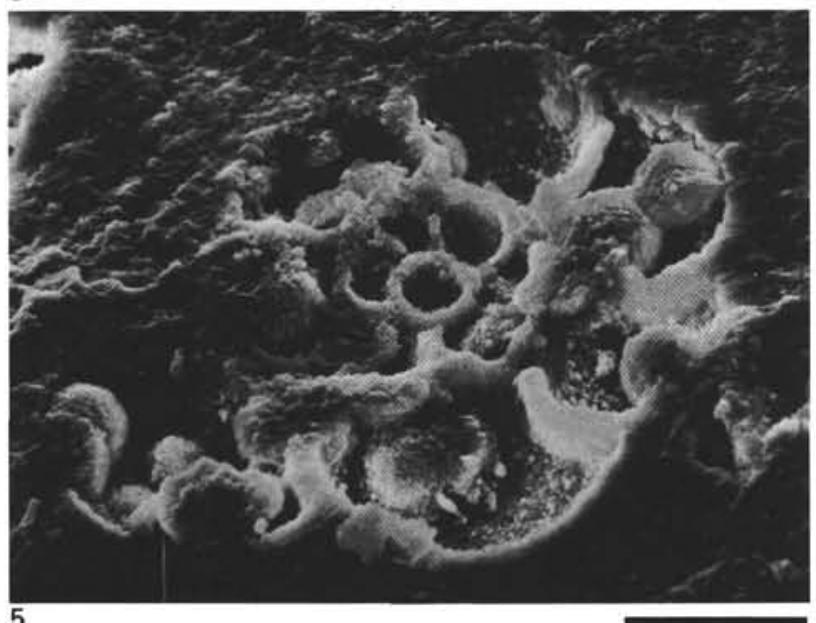

5

Plate 7. SEM photomicrographs of microfossils.

Figure 1. 464-11-1, $22 \mathrm{~cm}$; radiolarian filled with opal-CT blades and fragmented lepispheres in laminated quartz-opal-CT porcellanite. Scale is $30 \mu \mathrm{m}$.

Figure 2. Close-up of opal-CT blades in Figure 1. Blades are pure $\mathrm{SiO}_{2}$, whereas the highly altered radiolarian test and the webbed sphere growing in the radiolarian pore contain $\mathrm{Mn}$ as well as $\mathrm{SiO}_{2}$. Mn may be adsorbed on the reactive biogenic silica. Scale is $6 \mu \mathrm{m}$.

Figure 3. 464-14-1, $40 \mathrm{~cm}$; pyritic black chert containing recrystallized, quartz-replaced radiolarian(?) filled with bladed silica and carbonate debris replaced by silica. The granular host chert is
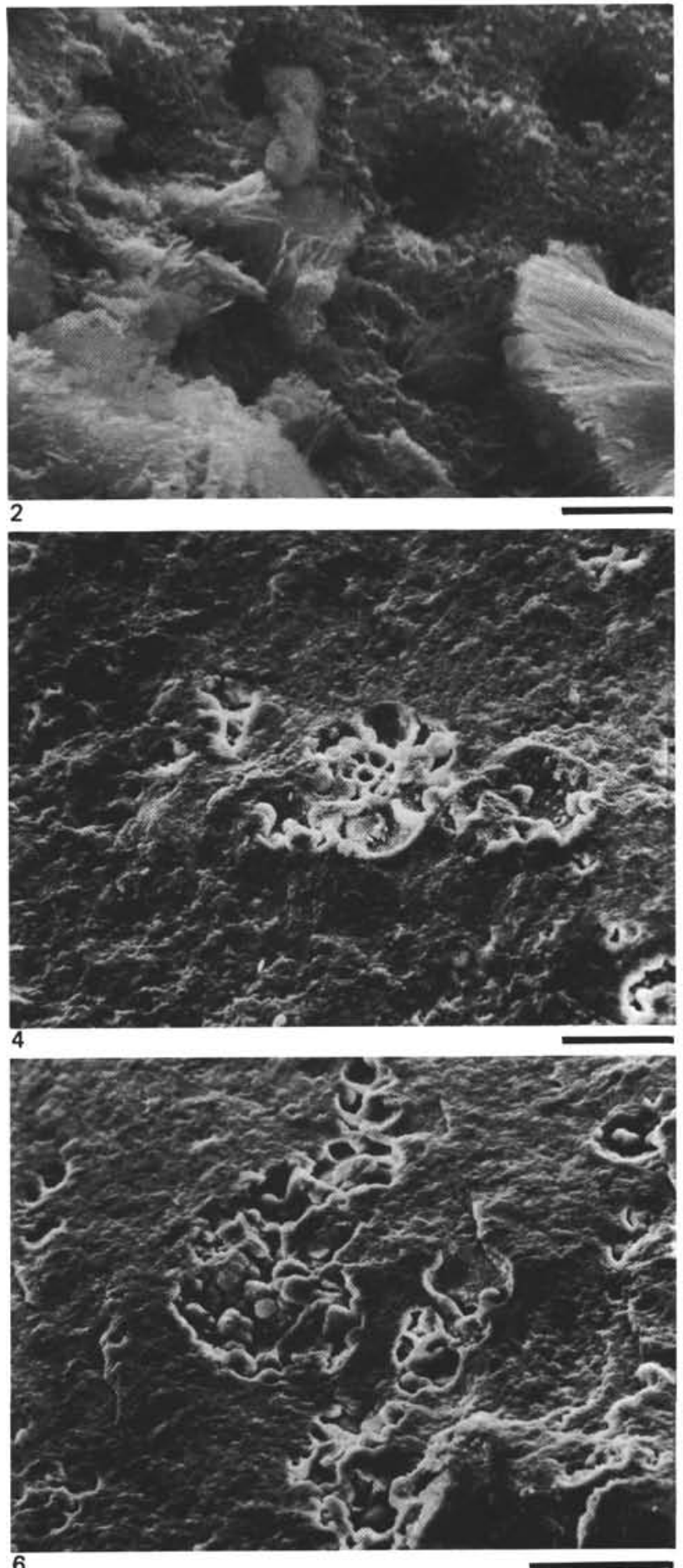

slightly calcareous in the area where the photograph was taken. Scale is $20 \mu \mathrm{m}$.

Figure 4. 464-27-1, $23 \mathrm{~cm}$; foraminifers concentrated at the boundary of a burrow (left and bottom) and the host jasper (upper right). The burrow is coarser-grained. Scale is $60 \mu \mathrm{m}$.

Figure 5. Close-up of central foraminifer in Figure 4, which was filled with opal-CT lepispheres subsequently replaced by quartz along with the test. Scale is $30 \mu \mathrm{m}$.

Figure 6. 464-27-1, $23 \mathrm{~cm}$; irregular voids filled with opal-CT lepispheres replaced by quartz, a typical feature of cherts in an intermediate stage of diagenesis. Voids are probably impressions of foraminifers. Scale is $100 \mu \mathrm{m}$. 

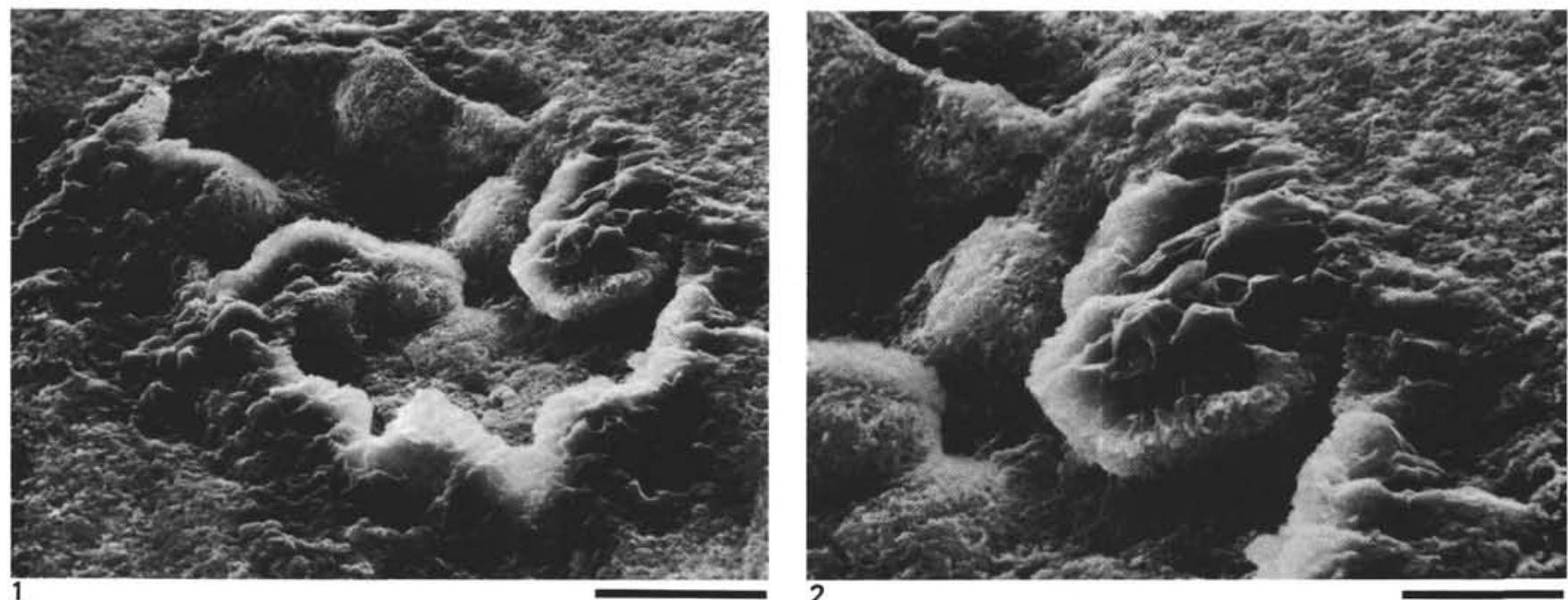

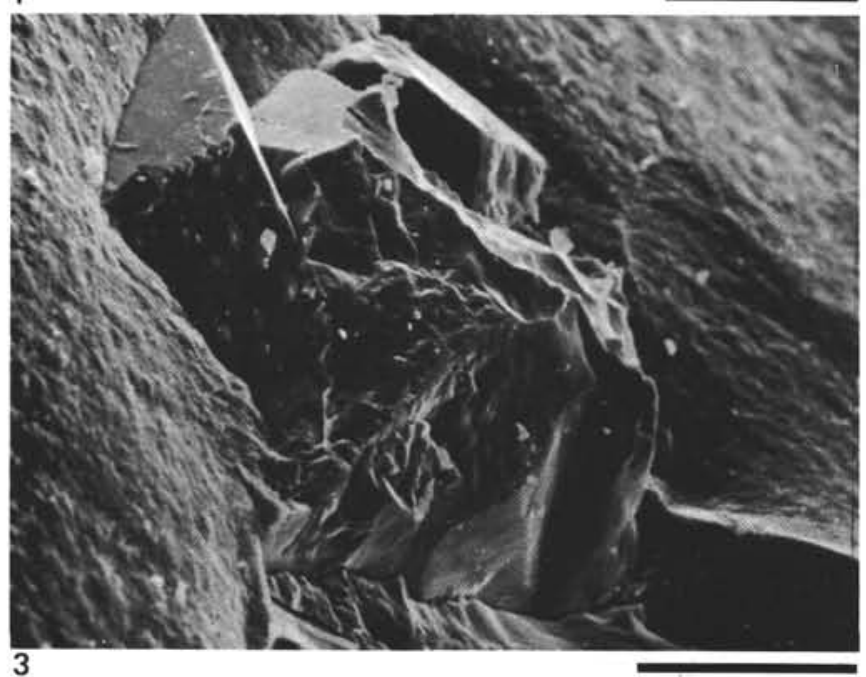

3

Plate 8. SEM photomicrographs.

Figure 1. 464-33-1, $14 \mathrm{~cm}$; highly modified microfossils (foraminifer tests?) in brown and red laminated chert. The test is granular microquartz and is filled by quartz-replaced lepispheres. Scale is 20 $\mu \mathrm{m}$.

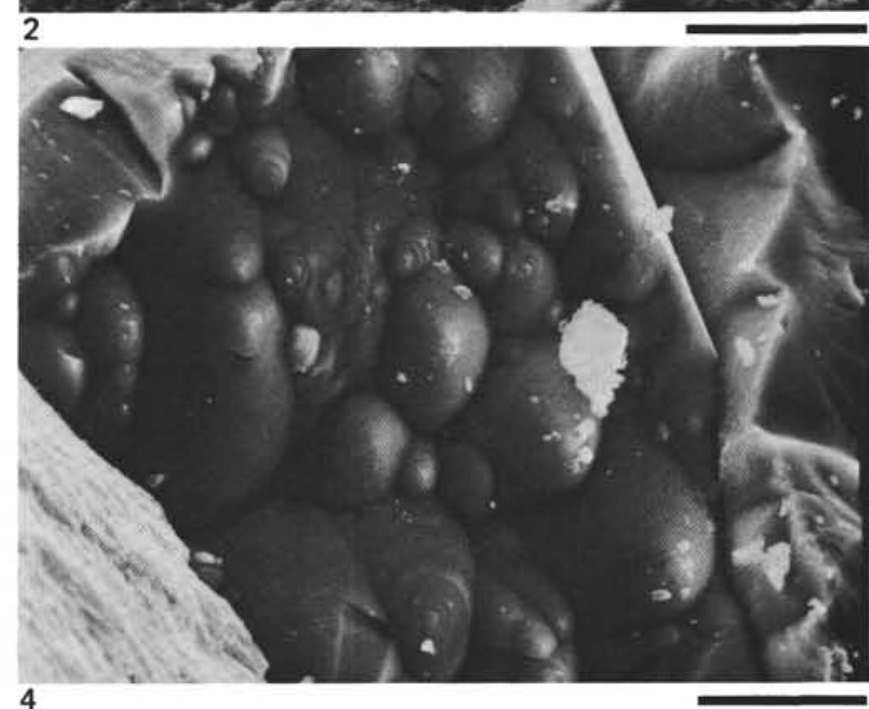

Figure 2. Close-up of part of Figure 1, showing center of spherule (relatively coarse microquartz). Scale is $10 \mu \mathrm{m}$.

Figure 3. 464-14-1, $40 \mathrm{~cm}$; pyrite crystal in black pyritic chert. Scale is $60 \mu \mathrm{m}$.

Figure 4 . Close-up of one face of pyrite crystal, showing odd circular growth bands of the pyrite. Scale is $10 \mu \mathrm{m}$. 

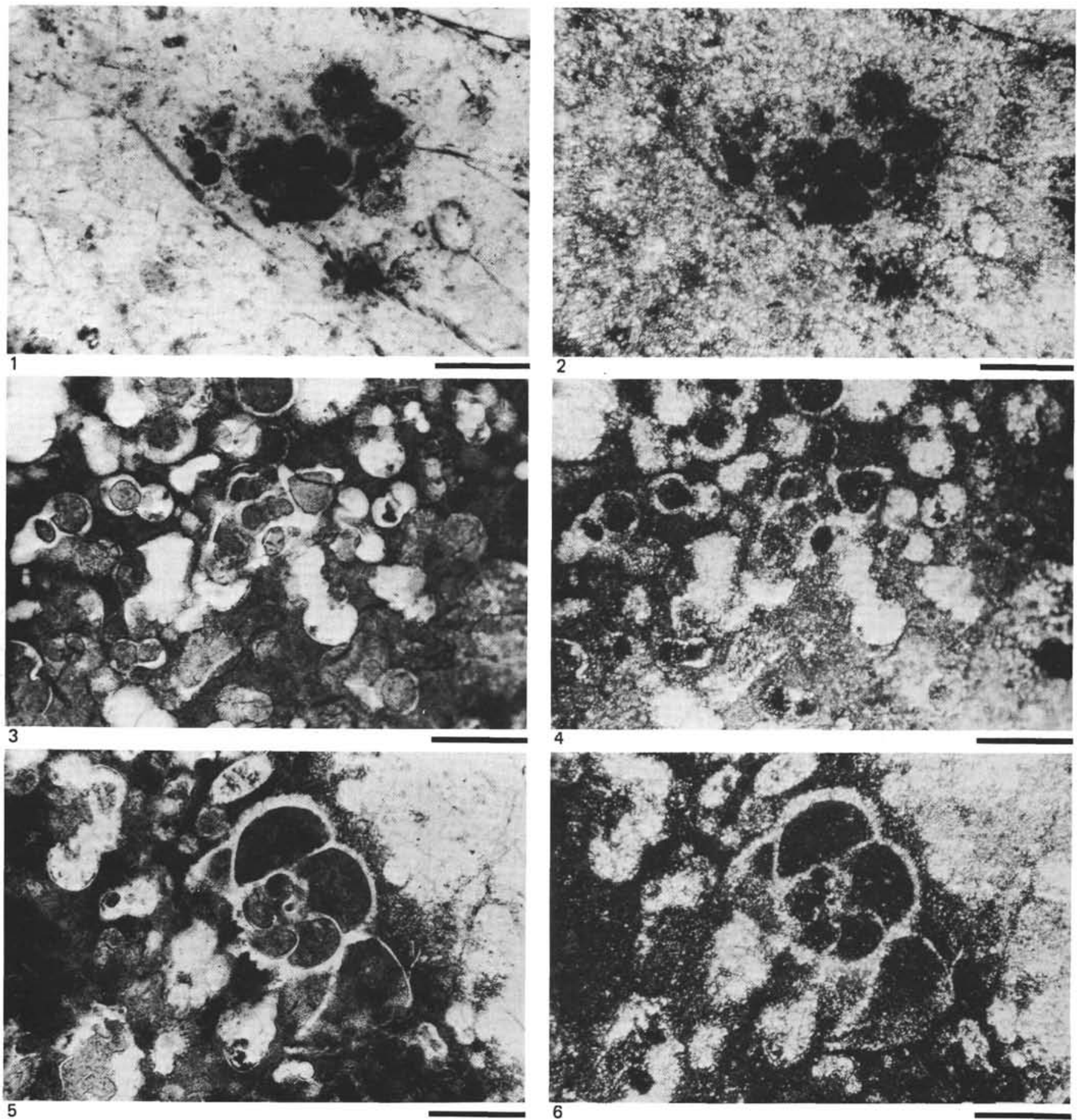

Plate 9. Thin-section photomicrographs of microfossils.

Figure 1. 463-9-3, $50 \mathrm{~cm}$; foraminifer replaced by and filled with hematite, in brown chert. Plane light; scale is $0.16 \mathrm{~mm}$.

Figure 2. As in Figure 1. Crossed nicols. Radiolarians are filled with microquartz.

Figure 3. 463-13-6, $98 \mathrm{~cm}$; foraminifers in opal-CT-rich porcellanite, replaced mainly by microquartz and filled by microquartz or opalCT. Plane light; scale is $0.16 \mathrm{~mm}$.

Figure 4. As in Figure 3. Cross nicols.

Figure 5. 463-13-6, $98 \mathrm{~cm}$; foraminifers and radiolarians in an opalCT rim adjacent to a quartz-replaced burrow (upper right). Foraminifers are replaced by quartz and filled with opal-CT, whereas radiolarians are filled with microquartz. Within the quartz burrow, radiolarians are ghosts, and foraminifers are not recognizable. Plane light; scale is $0.64 \mathrm{~mm}$.

Figure 6. As in Figure 5. Crossed nicols. 

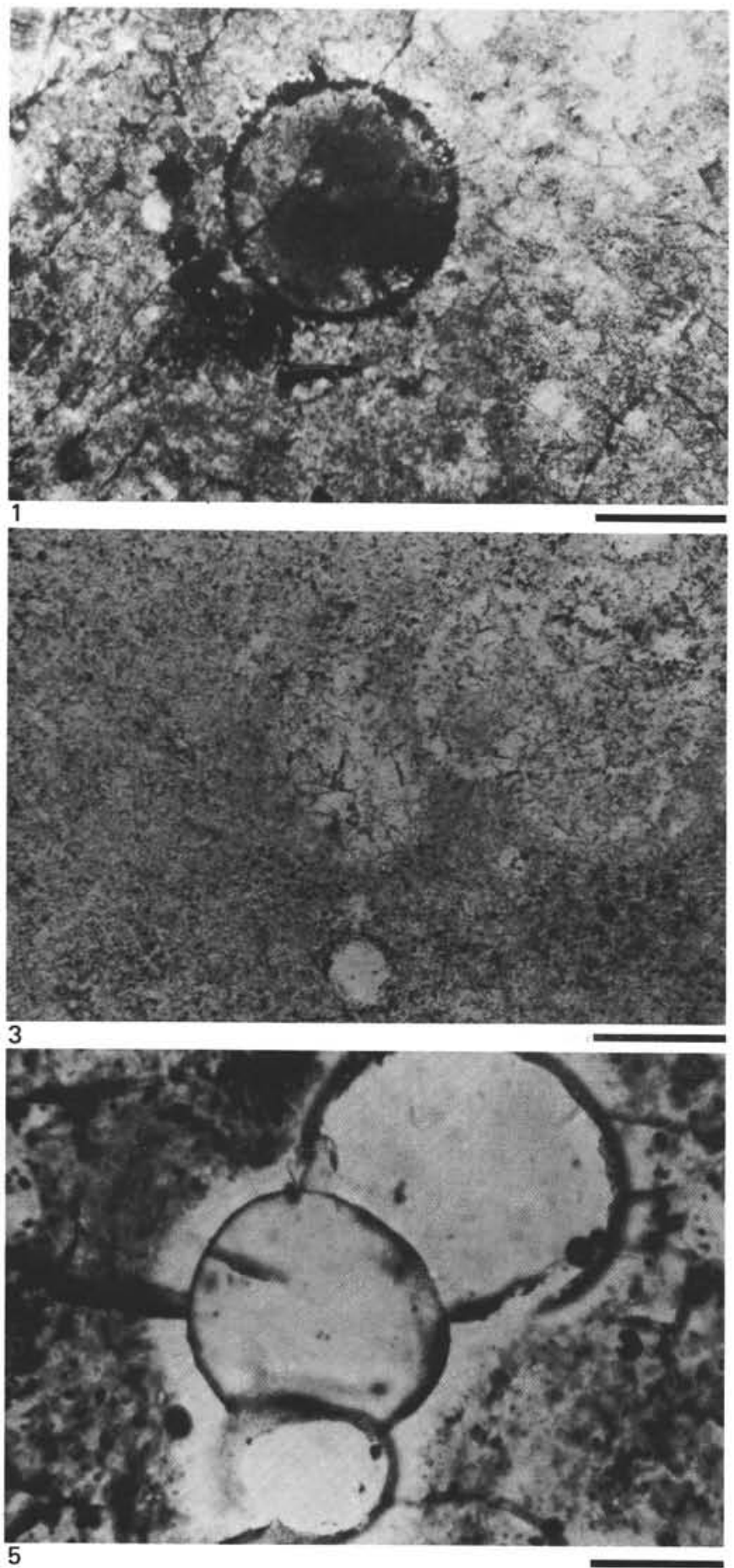

Plate 10. Thin-section photomicrographs of microfossils.

Figure 1. 464-29-1, $65 \mathrm{~cm}$; radiolarian replaced and partly filled by hematite, in a brown chert. Plane light; scale is $0.16 \mathrm{~mm}$.

Figure 2. As in Figure 1. Crossed nicols.

Figure 3. 465-2,CC; chalcedony-replaced and -filled radiolarian and a foraminifer ghost (upper right) in calcareous chert. Plane light; scale is $0.16 \mathrm{~mm}$.

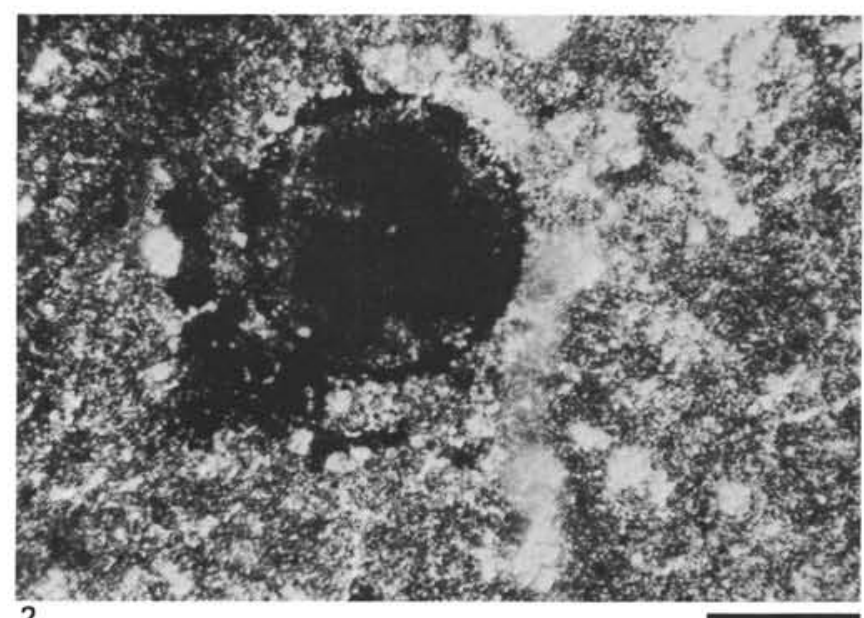

2

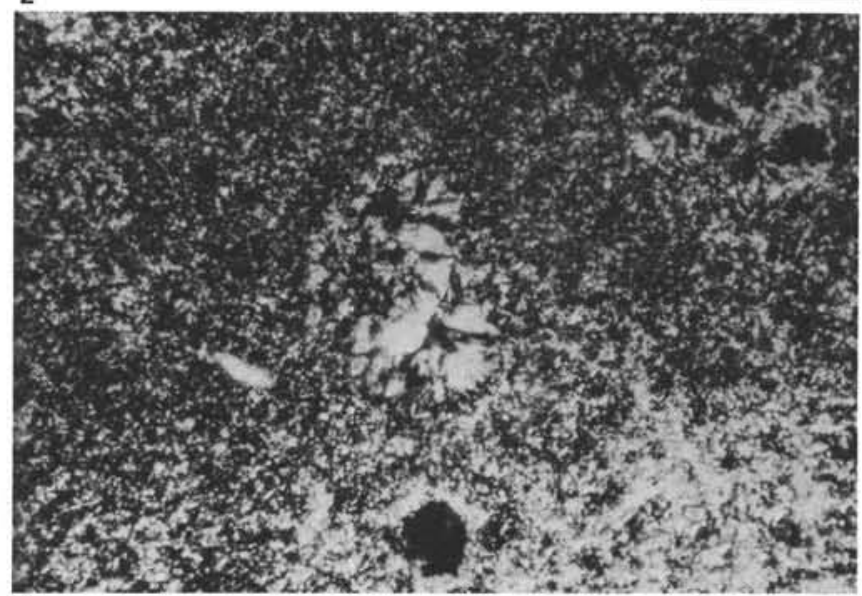

4

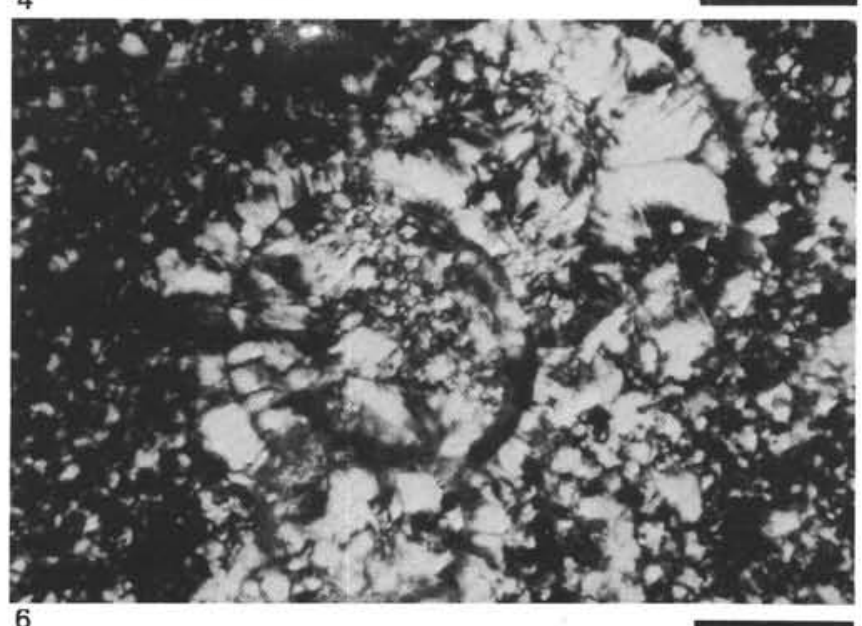

Figure 4. As in Figure 3. Crossed nicols. Except for one chamber (top right corner), the foraminifer in Figure 3 essentially disappears with crossed-nicols.

Figure 5. 465A-26-1, $91 \mathrm{~cm}$; quartz-replaced foraminifer. Quartz crystals are pseudomorphs after the test calcite crystals, which were oriented perpendicular to the test walls. The foraminifer is filled with microquartz and chalcedony. Plane light; scale is 0.04 $\mathrm{mm}$.

Figure 6. As in Figure 5. Crossed nicols. 

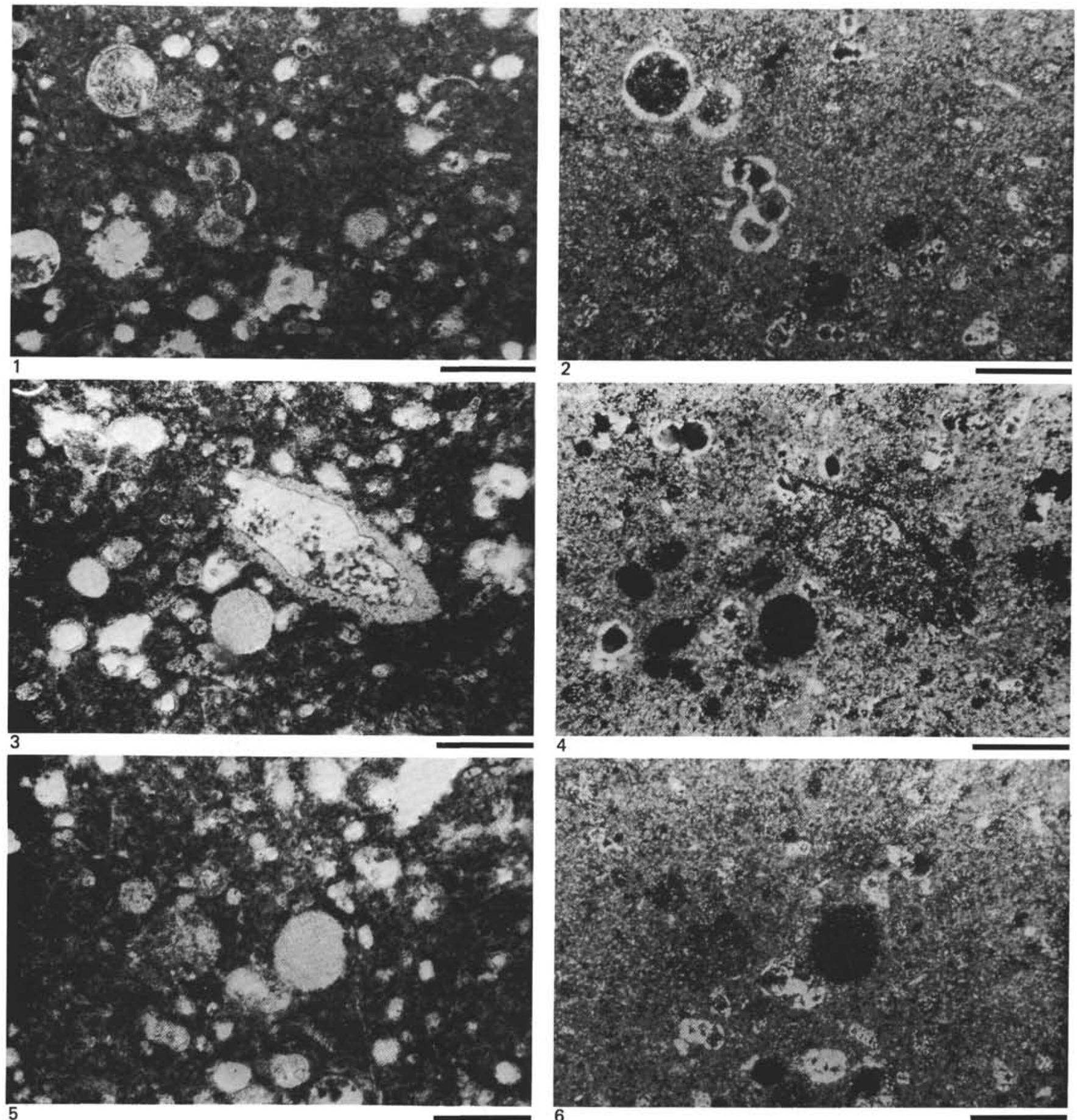

Plate 11. Thin-section photomicrographs of microfossils in calcareous opal-CT-quartz porcellanite, $466-34-1,77 \mathrm{~cm}$. Scales are $0.16 \mathrm{~mm}$.

Figure 1. Plane light.

Figure 2. Crossed nicols. The two large foraminifers with bright walls consist of recrystallized calcite and are filled with opal-CT. The radiolarian in the upper left is replaced by opal-CT and filled with microquartz.

Figure 3. Plane light.

Figure 4. Crossed nicols. Microfossils filled with and replaced by opal-CT, and many small foraminifers consisting of recrystallized

4

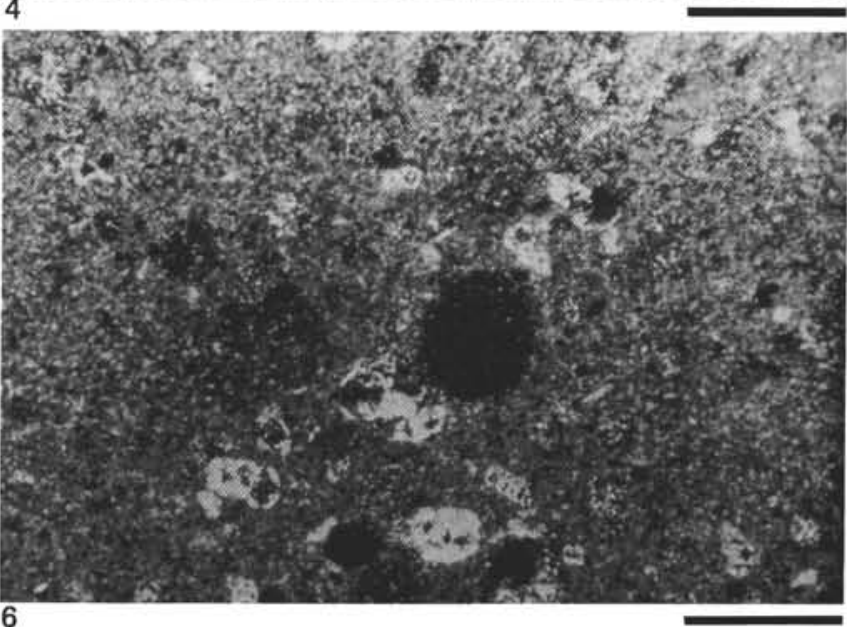

calcite. The origin of the large central structure is unknown, but it is filled with an intimate mixture of opal-CT and microquartz.

Figure 5. Plane light.

Figure 6. Crossed nicols. Much structural detail remains on the test of the radiolarian (left center) replaced by opal-CT. Other microfossils are filled with calcite, microquartz, or opal-CT. The radiolarian to the left of center at the top is filled with microquartz, except for a group of opal-CT lepispheres that make up the dark area in the lower part of the test. 

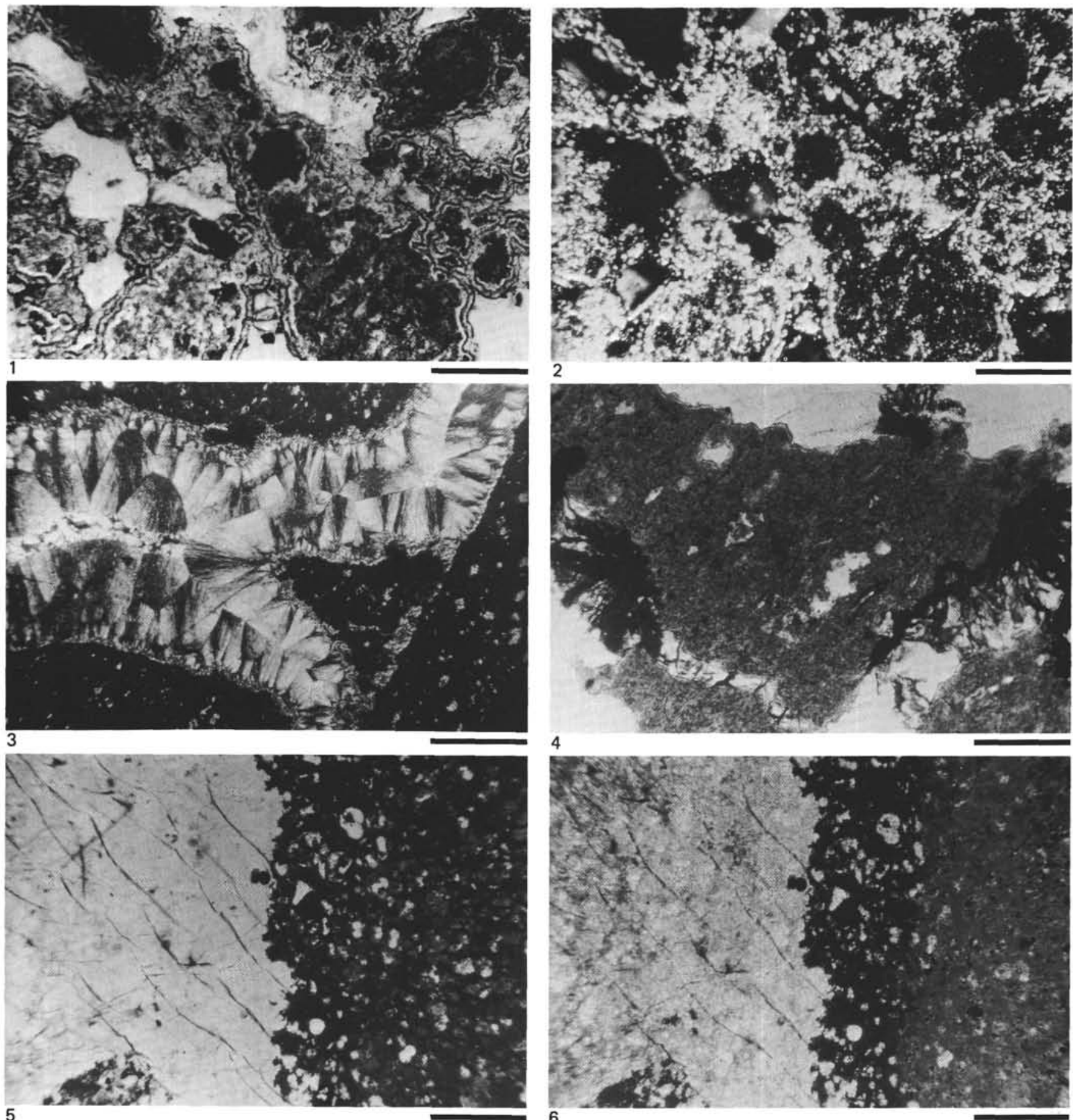

Plate 12. Thin-section photomicrographs.

Figure 1, 464-11-1, $5 \mathrm{~cm}$; chert breccia. White areas are voids (black under crossed nicols); darker areas are clasts cemented by colloform opal-CT and chalcedony. Plane light; scale is $0.16 \mathrm{~mm}$.

Figure 2. Crossed nicols.

Figure 3. 464-11-1, $22 \mathrm{~cm}$; vein of quartz and chalcedony in laminated porcellanite. Vein is lined by fine-grained microquartz, as is the triangular clast of host sediment trapped in the vein. Precipitation of microquartz was followed by precipitation of chalcedony, followed by precipitation of coarser-grained microquartz in pockets at the center of the vein (left center). The vein, as well as

the clast of host sediment, are lined by radiating fibers of $\mathrm{Fe}-\mathrm{Mn}$ oxides. Crossed nicols; scale is $0.64 \mathrm{~mm}$.

Figure 4. Close-up of clast inclusion in the vein shown in Figure 3. Note the dark Fe-Mn fibers growing out from the clast into the vein. These fibers occur along the length of the vein. Plane light; scale is $0.16 \mathrm{~mm}$.

Figure 5. 463-9-3, $50 \mathrm{~cm}$; plane light.

Figure 6. Crossed nicols; typical sequence from siliceous chalk (at right) through an inclusion-rich opal-CT transition zone, to microquartz chert (left). Note the sharp chert/porcellanite contact and more-transitional porcellanite/chalk contact. Microfossils end abruptly at the edge of the chert. Scales are $0.64 \mathrm{~mm}$. 

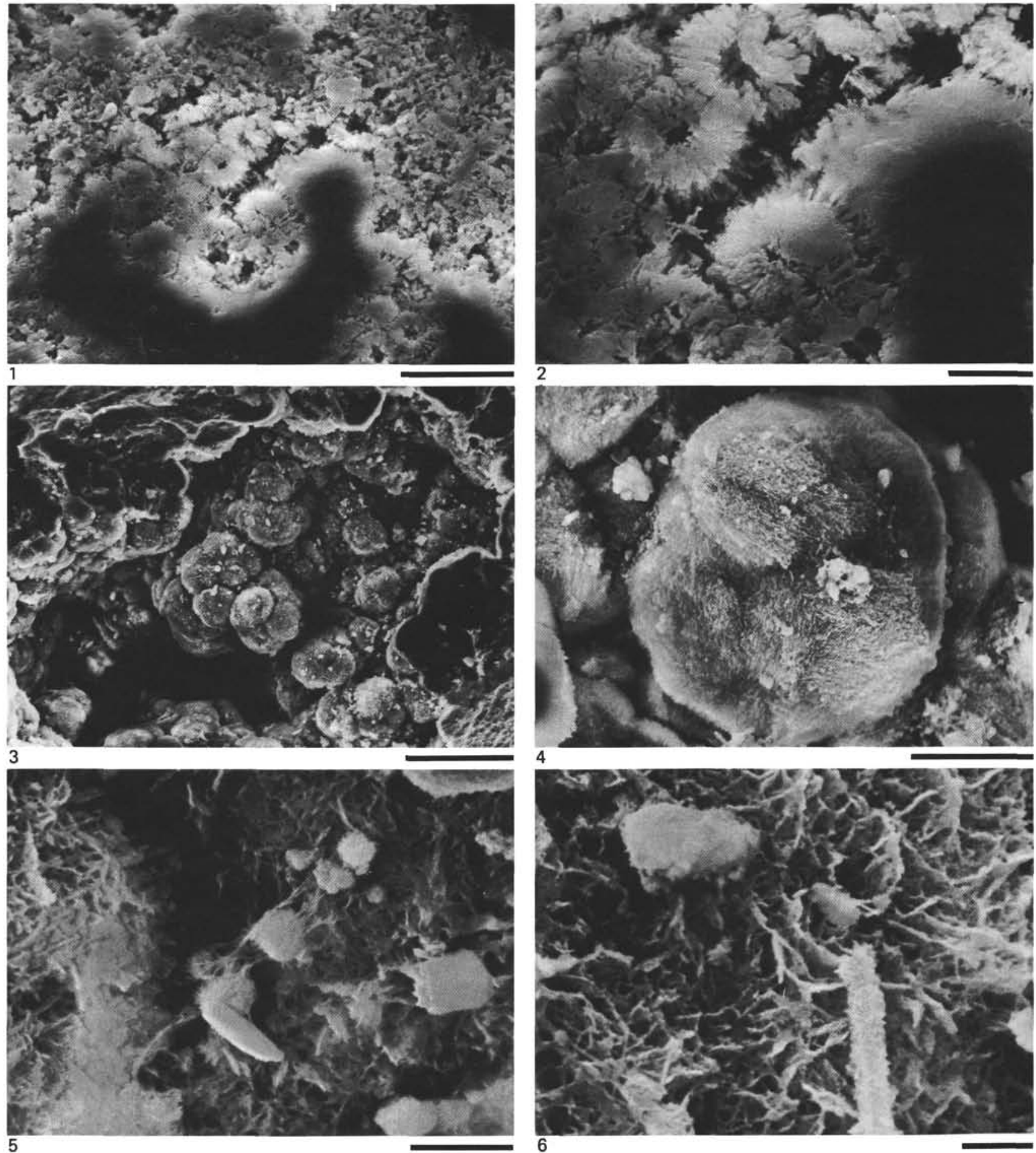

Plate 13. SEM photomicrographs.

Figure 1. 463-31,CC; radial clusters of opal-CT with hollow centers, and patches of massive quartz (dark areas, lower half of photo). See text and text Figure 5 for an explanation of these uncommon structures. Scale is $20 \mu \mathrm{m}$.

Figure 2. Close-up of part of Figure 1. Note how the radial fibers feed the massive quartz (dark area at the right). Scale is $6 \mu \mathrm{m}$.

Figure 3-6. 464-11-1, $5 \mathrm{~cm}$; opal-CT cement of a chert breccia. The opal-CT and chalcedony form a colloform texture (see Plate 12, Figs. 1, 2). The opal-CT spheres (Fig. 3) are much larger than typical lepispheres described from the deep sea (Hein et al., 1978), and

are grouped in clusters, each sphere made up of "fused" smaller bladed spheres (Fig. 4); even these smaller spheres are larger than lepispheres. The surfaces of the spheres are the loci for precipitation of other authigenic minerals. The small 2- to 3-mm sphere in (Figure 5) has $\mathrm{Mn}, \mathrm{Si}$, and a trace of $\mathrm{Fe}$ (EDAX spectrum). The chemistry of the fine-webbed mineral could not be measured, but is probably some form of silica. Levitan and Lisitsyn (1977) suggested that similar features in cherts from the central Pacific were formed during extension of an extremely viscous colloidal silica film. Figure 6 is a close-up showing the apparently random orientations of the crudely formed, pure- $\mathrm{SiO}_{2}$ blades. Scales are 100 , 20,6 , and $3 \mu \mathrm{m}$, respectively. 


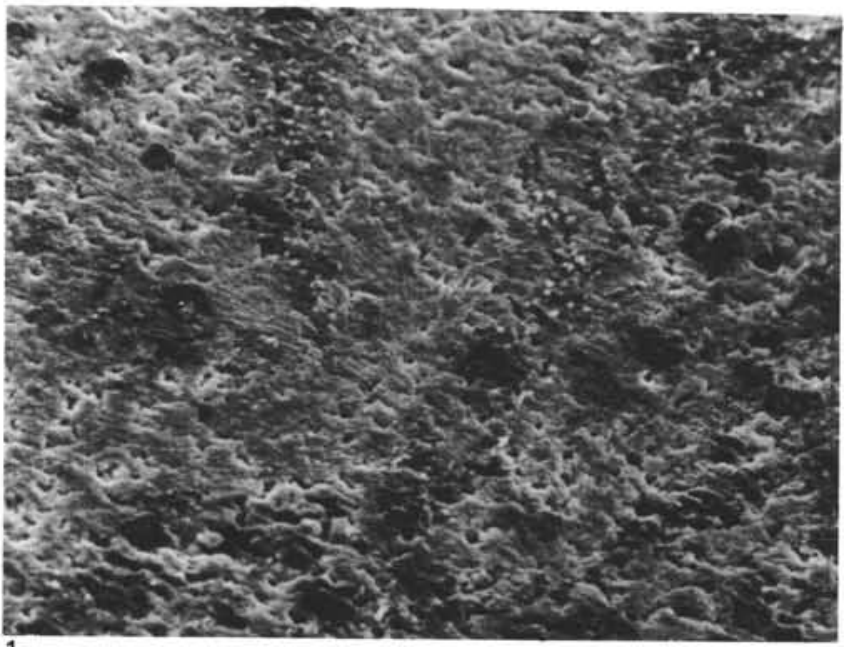

1

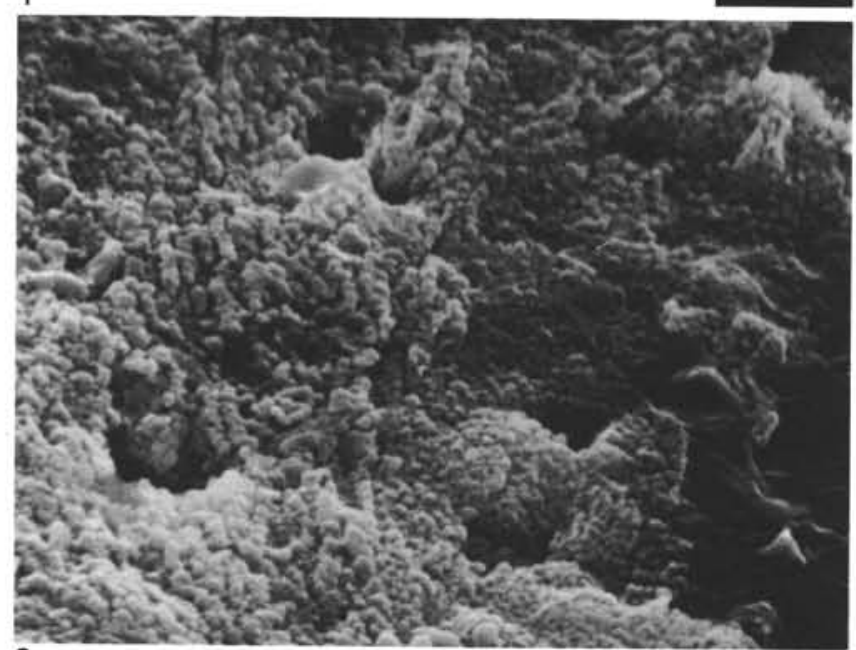

3

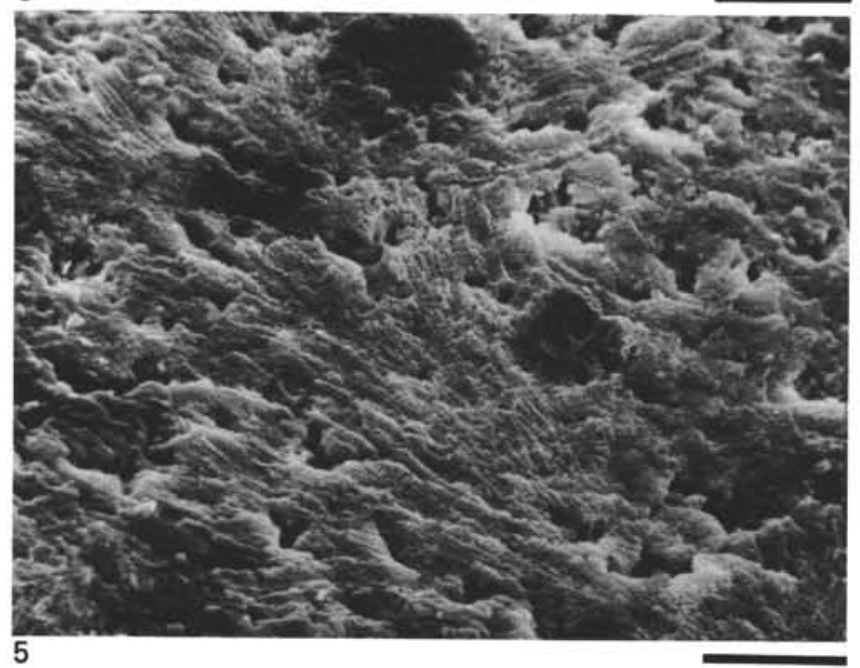

Plate 14. SEM photomicrographs of $465-5-2,118 \mathrm{~cm}$. Scales are 60 , $30,6,10,20$, and $20 \mu \mathrm{m}$, respectively.

Figure 1. General view of a gray chert fracture surface. Dark areas are massive quartz (EDAX showed $\mathrm{Si}$, trace $\mathrm{Na}$ ), the rest of the surface is quartz which replaced calcite microspherules (EDAX showed $\mathrm{Si}$, minor $\mathrm{Ca}$ ).

Figure 2. Close-up of center of Figure 1.
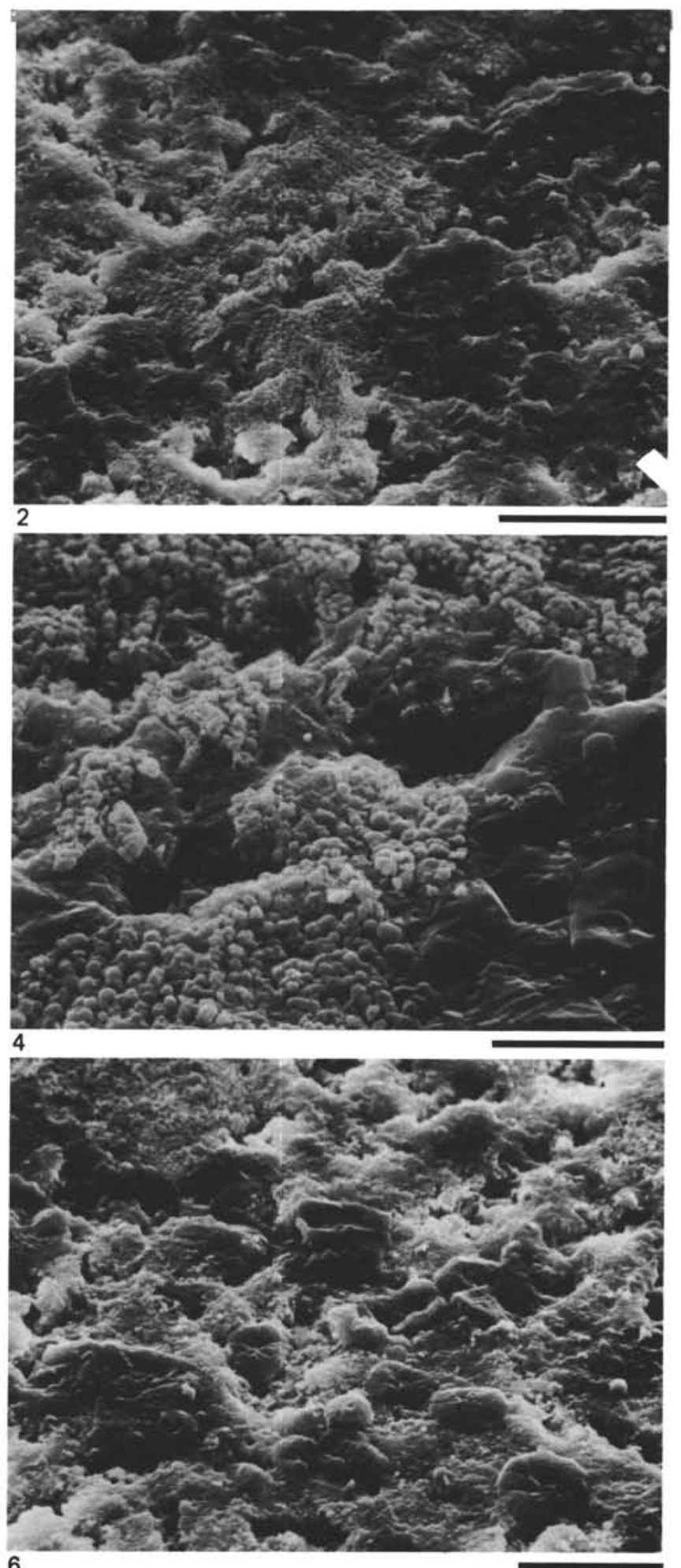

Figure 3. Close-up of center of Figure 2. Microspherules are about $0.3 \mu \mathrm{m}$ in diameter.

Figure 4. Close-up of center of Figure 2. Crystals of various crystallographies were replaced by silica in the dense quartz masses.

Figure 5. In places, the microspherule fabric shows a preferred, commonly branching orientation.

Figure 6. In places, the surface is studded with silica crystals that contain a trace of $\mathrm{Na}$ and are possibly quartz pseudomorphs after sulfates. 

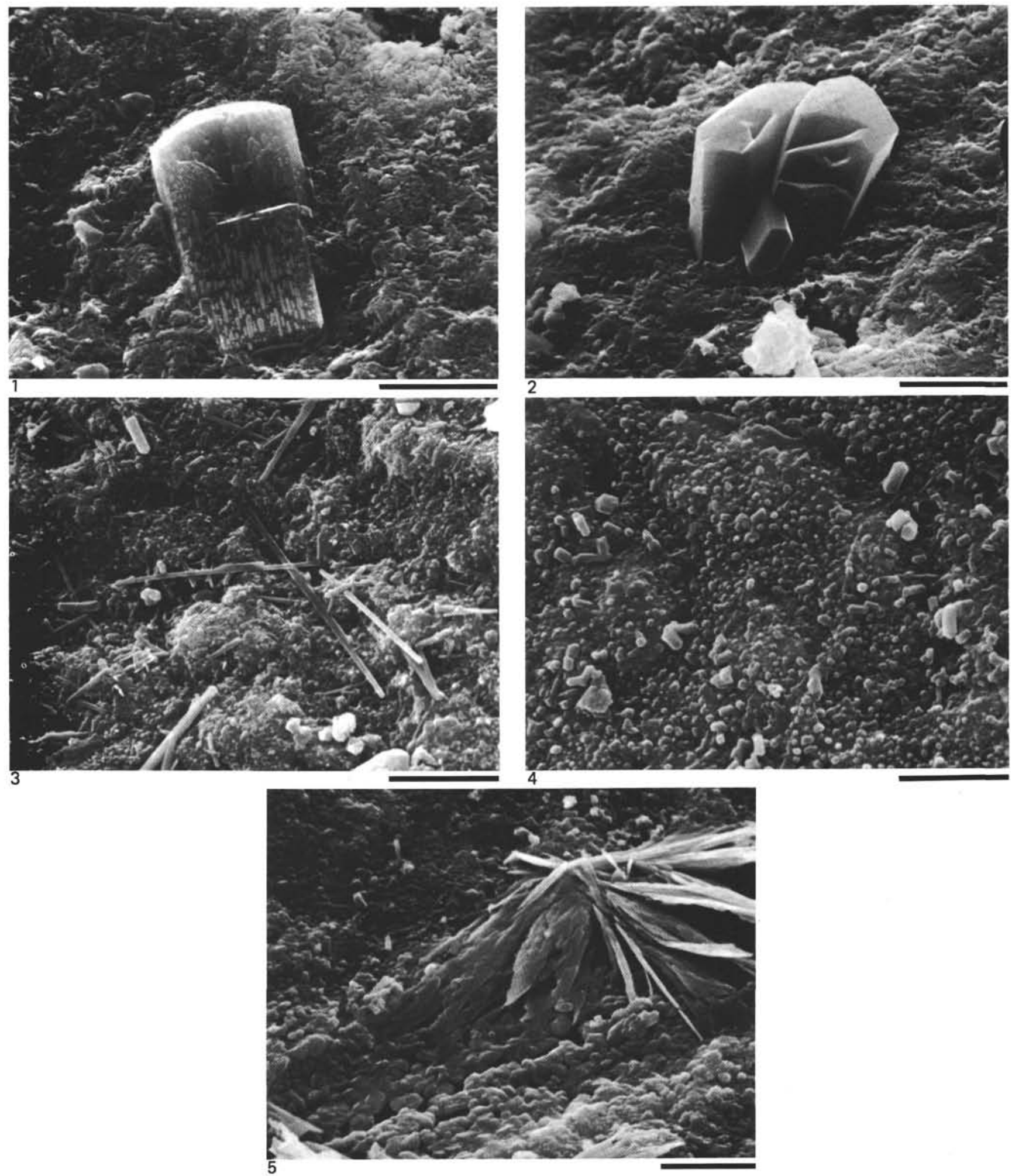

Plate 15. SEM photomicrographs. Figures 1-4 represent 465-2,CC. All scales are $6 \mu \mathrm{m}$.

Figure 1. Quartz pseudomorph after gypsum or anhydrite. The EDAX spectrum recorded $\mathrm{Si}$ and a trace of $\mathrm{Na}$ for the crystal, $\mathrm{Na}$ being more concentrated in the elongate, light-colored fluid inclusions. The inclusions (sea water?) apparently were not displaced by the silicification of the crystal. The host chert has an EDAX spectrum of Si only.
Figure 2. The many quartz crystals in this translucent gray chert all contain a trace of $\mathrm{Na}$.

Figures 3,4 . In places the chert surface consists of minute stubby rods, and of long blades whose EDAX spectra are $\mathrm{Si}$ and trace Na.

Figure 5. 465-5-2, $118 \mathrm{~cm}$; same sample as in Plate 14; gypsum sheaths are obviously part of the chert and merge with the granular-quartz host chert. EDAX spectrum of the blades is $\mathrm{Ca}, \mathrm{S}$. The gypsum is partly replaced by silica. 